\title{
Spatially limited mud turbidites on the Cascadia margin: segmented earthquake ruptures?
}

\author{
C. Goldfinger ${ }^{1}$, A. E. Morey ${ }^{1}$, B. Black ${ }^{1}$, J. Beeson ${ }^{1}$, C. H. Nelson ${ }^{2}$, and J. Patton ${ }^{1}$ \\ ${ }^{1}$ Oregon State University, College of Oceanic and Atmospheric Sciences, 104 Ocean Admin. Bldg., \\ Corvallis, Oregon 97331, USA \\ ${ }^{2}$ Instituto Andaluz de Ciencias de la Tierra (IACT), CSIC-Univ. de Granada, Campus de Fuentenueva s/n, \\ 18002 Granada, Spain \\ Correspondence to: C. Goldfinger (gold@ coas.oregonstate.edu) and C. H. Nelson (odp@ugr.es) \\ Received: 2 December 2011 - Published in Nat. Hazards Earth Syst. Sci. Discuss.: - \\ Revised: 20 April 2013 - Accepted: 20 May 2013 - Published: 23 August 2013
}

\begin{abstract}
A series of 23 thin, mostly mud-silt turbidites are found interspersed between larger, well-dated and regionally correlated paleoseismic sandy turbidites that extend along most of the Cascadia margin, northwestern United States. Investigation of the structure, distribution, and sedimentology of these thin mud-silt units supports the interpretation of these units as turbidites originating on the continental slope. Interpretation of mud turbidites is inhibited by bioturbation and lower response to analytical and imaging techniques; nevertheless most of the 23 interpreted beds exhibit most of the characteristics of coarser turbidites. These characteristics include sharp bases, fining upward sequences, darker color, increased gamma and CT density and magnetic susceptibility relative to the hemipelagic background, sparse microfossils, high lithic content, and evidence of transport from marine sources on the continental slope. New core data from sites south of Rogue Apron indicate that sandy and muddy turbidites may be correlated at least $150 \mathrm{~km}$ south to Trinidad Plunge Pool for the period $\sim 4800 \mathrm{yr}$ BP to present. Many of the mud turbidites initially described at Rogue Apron coarsen southward, becoming sandy turbidites. Highresolution Chirp seismic profiles reveal that turbidite stratigraphy along the base of the southern Cascadia continental slope is continuous, with little variation for at least $240 \mathrm{~km}$ along strike. The Chirp data show that turbidites along the Cascadia base of slope are ubiquitous, and likely not sourced solely from submarine canyon mouths, but may also have been delivered to the proximal abyssal plain as sheet flows from the open continental slope and coalescing local sources. Regional stratigraphy reveals that hemipelagic sedimentation
\end{abstract}

rates and total Holocene turbidite thickness and mass are similar at widely separated sites, yet the total thickness of the Holocene section is greater by a factor of two in southern Cascadia. This difference is primarily due to the presence of the 21 mud and two additional sandy turbidites. We conclude that the Cascadia mud turbidites are ubiquitous along southern Cascadia only, with only one likely example of a correlated turbidite limited to the northern margin. Eight onshore sites including three marsh sites and five lakes include potential seismogenic correlatives of the southern Cascadia turbidites. In all, the onshore sites may have recorded $>80 \%$ of the events attributed to plate boundary earthquakes offshore during the period 0-6000 yr ago. Slope stability calculations suggest that earthquakes of $M_{\mathrm{w}}=7.0$ or greater should generate ground accelerations sufficient to destabilize open slopes and canyon heads with or without excess pore fluid pressure. Estimates of Mw for segmented ruptures are in the range of 7.4-8.7, exceeding the slope stability criteria for typical slopes by at least a factor of $\sim$ four.

\section{Introduction}

Quantifying the temporal and spatial patterns of great subduction earthquakes through time remains elusive because our instrumental strain observations (GPS, strain meters, and seismology) commonly span one seismic cycle or less. Fundamental questions regarding segmentation, clustering, and the applicability of long-term slip models remain unanswered because we rarely have a long enough temporal and 
spatial earthquake series. Paleoseismology addresses these issues directly by using a longer span of time, adding new insights into the workings of major fault systems.

Onshore paleoseismology first illuminated the Cascadia earthquake record, and similar investigations are underway in other subduction systems. Coastal records can typically define earthquake histories over the past 1000-3000 yr, with scattered longer records. The marine sedimentary record contains a long and uninterrupted turbidite record that can be readily sampled to lengths of $\sim 10000 \mathrm{yr}$, more than enough to encompass many seismic cycles. In recent years, turbidite paleoseismology has been developed in Cascadia (Adams, 1990; Goldfinger et al., 2003a,b, 2008, 2009, 2012; Dallimore et al., 2005; Blaise-Stevens et al., 2011; Enkin et al., 2013), Japan (Inouchi et al., 1996; Shiji et al., 2000a,b; Nakajima and Kanai, 2000; Noda et al., 2008), the Mediterranean (Anastasakis and Piper, 1991; Kastens, 1984; Pareschi et al., 2006; Cita and Aloisi, 2000), the Dead Sea (Niemi and Ben-Avraham, 1994), the Northern San Andreas Fault (Goldfinger et al., 2003a,b, 2007, 2008); Sumatra (Patton et al., 2009), the Marmara Sea (McHugh et al., 2006), New Zealand (Pouderoux et al., 2012), and in numerous inland lakes (e.g., Karlin et al., 2004; Schnellman et al., 2002; Moernaut et al., 2007; Waldmann et al., 2011; St-Onge et al., 2004; Seitz and Kent, 2005; Strasser et al., 2006; Chapron et al., 2006) and many other localities.

Turbidite paleoseismology requires discrimination between earthquake generated turbidity currents, and those triggered by other mechanisms. Adams (1990) suggested four plausible mechanisms for turbidity current triggering: (1) storm wave loading; (2) great earthquakes; (3) tsunamis and (4) sediment loading. To these we add (5) crustal earthquakes, (6) slab earthquakes, (7) hyperpycnal flow, and (8) gas hydrate destabilization. All of these mechanisms can and do destabilize slopes and may be related to the triggering of turbidity currents, but can earthquake-triggered turbidites be distinguished from others? Two approaches may be used to help distinguish seismic from non-seismic turbidites: (1) sedimentological determination of turbidite origin, and (2) regional turbidite correlations that require synchronous and widespread (i.e., earthquake) triggering. The development of methodologies to apply these two techniques to local and regional submarine paleoseismic problems are discussed extensively in Adams (1990), Goldfinger et al. (2003a, 2007, 2008, 2009, 2012), Shiki et al. (2000), Nakajima and Kanai (2000) and other sources.

A series of 19 Cascadia turbidites has been attributed to great subduction earthquakes based on stratigraphic correlation, radiocarbon evidence, consistency over much of the $1000 \mathrm{~km}$ length of the Cascadia margin, and close correspondence with other lines of evidence from paleoseismic sites onshore (Adams, 1990; Goldfinger et al., 2003, 2008, 2012). The 19 regional Holocene turbidites establish an average recurrence time of $\sim 500 \mathrm{yr}$, with interevent times varying from $\sim 200-1200 \mathrm{yr}$, and exhibits temporal clustering
(Kelsey et al., 2005; Goldfinger et al., 2012). In recent years, investigators working onshore have suggested that there may also be segmented ruptures of the Cascadia margin. Existing evidence suggests that segmented ruptures primarily affect southern Cascadia based on mismatching ${ }^{14} \mathrm{C}$ ages along strike (Nelson et al., 2006, 2008; Kelsey et al., 2005), and on the higher recurrence frequency from southern Cascadia marsh, estuary and lake paleoseismic sites (Kelsey et al., 2002, 2005; Witter et al., 2003; Kelsey and Witter, 2004). Goldfinger et al. (2012) observed that there is significant commonality between the onshore and offshore paleoseismic records. Based on this commonality and along-strike correlation of offshore turbidites, they proposed a model of segmented ruptures during the Holocene that attempts to integrate onshore and offshore records.

Offshore evidence of rupture segmentation initially reported in Goldfinger et al. $(2008,2012)$ was based on observation of a series of thin, mostly mud-silt turbidites interspersed between larger, well-dated and regionally correlated sandy turbidites that extend along most of the Cascadia margin. Mud turbidites have now been recognized in a number of settings as the result of more dilute, slower moving cousins to the more commonly reported turbidity currents that transport sand-sized material and leave more robust stratigraphic evidence (Hesse, 1975; Stow and Bowen, 1980; Piper, 1978; Brunner and Ledbetter, 1985, 1987, 1989; Piper and Deptuck, 1997; Curran et al., 2004). Mud turbidites are now recognized as making up a high proportion of material flux to the deep ocean relative to their more proximal sandy counterparts (Rupke and Stanly, 1974; Einsele and Kelts, 1982; Stow and Piper, 1984; Porebski et al., 1991; Awadallah, 2001; Zúñiga et al., 2007)

Goldfinger et al. (2012) argue that the evidence for correlated turbidites limited to southern Cascadia is consistent along strike, and in some cases, with the onshore paleoseismic data. Analysis of the onshore data and turbidite data as a whole revealed some potential problems with the onshore time series, which were corrected in a collaborative effort with the original authors, and incorporated in the database and results of Goldfinger et al. (2012). This effort yielded a stratigraphic record including 41 turbidites at Rogue Apron, at the mouth of Rogue Canyon offshore southern Oregon, and tentative correlations farther south. The potential correlative onshore sites include Bradley Lake, the Sixes River and Coquille River estuaries, located in a similar latitude range near the Rogue River/Canyon system (Fig. 1).

With improvements in the time series from many new ${ }^{14} \mathrm{C}$ ages and age estimates from hemipelagic sedimentation rates, the onshore-offshore fit of the time series of paleoseismic data was improved (see Goldfinger et al., 2012). However, the proposed segmented ruptures required further investigation into the occurrence, nature, and correlation (or lack thereof) of the interpreted mud turbidites among core sites. In this paper, we examine the record of mostly thin mudsilt turbidites along the southern Cascadia margin in more 


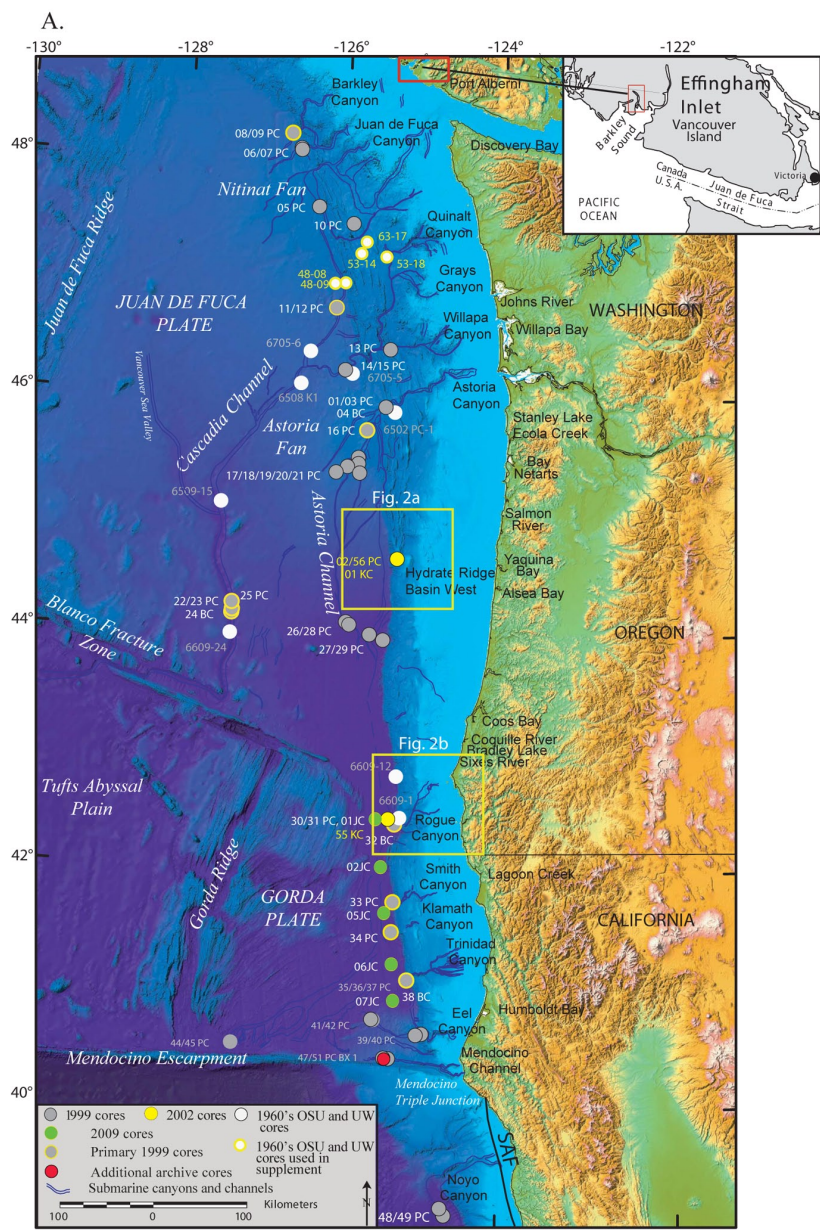

B.

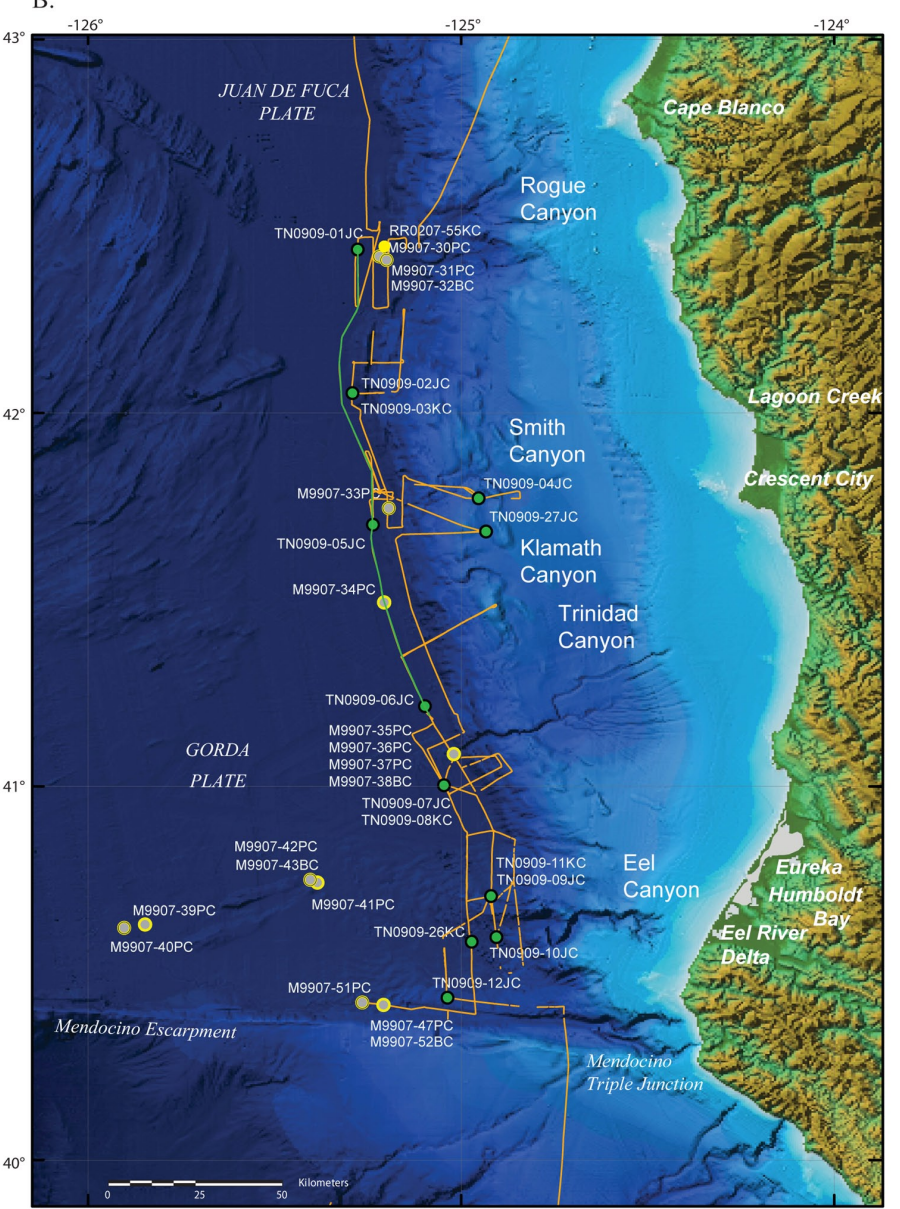

Fig. 1. (A) Cascadia margin turbidite canyons, channels and 1999-2002 core locations. Major canyon/channel systems are outlined in blue. Primary core sites shown with yellow rim, all other 1999-2002 cores are grey. Selected earlier UW and OSU cores shown in white. PC, piston core; BC, box core; KC, kasten core; GC, gravity core; TC, trigger core. Trigger cores omitted for clarity. Inset of Effingham Inlet shows collection site of Pacific Geoscience Centre (PGC) collected piston cores. Yellow boxes indicate approximate areas of Fig. 2a and b. Key onshore paleoseismic sites shown. (B) Southern Cascadia continental margin bathymetry and core sites in greater detail. Core symbology as in (A). The $3.5 \mathrm{kHz}$ Chirp profile tracklines are shown. Segments used in Figs. 9 and 10 shown in green, others in orange. Key onshore paleoseismic sites shown.

detail with additional analyses using new cores. We also use new CT (computed tomography) data from the Cascadia offshore cores along strike. We focus on southern Cascadia using 13 new cores collected in 2009 between Rogue Apron and Trinidad Plunge Pool. We discuss a preliminary investigation of turbidites discovered in four lakes in the southern Cascadia coast range reported in a companion paper (Morey et al., 2013), along with existing onshore paleoseismic sites in southern Cascadia. We also add seismic-stratigraphic correlation to the suite of tools we are employing to build on and test the stratigraphic framework for intersite correlation previously constructed using core lithostratigraphy, physical property correlations and radiocarbon data alone (Goldfinger et al., 2012).

\subsection{Data and methods}

\subsubsection{Lithostratigraphic correlation}

All cores (Fig. 1) were scanned with a Geotek multisensor logger that collects high-resolution visible imagery, gamma density, magnetic susceptibility, $P$ wave velocity, and resistivity (core locations are given in the Supplement, Tables S1 and S2). Cores were then split for visual description and collection of high-resolution line-scan and CT imagery. Subsequently, high-resolution point magnetic susceptibility data were collected from each core using a point sensor (Bartington MS2E high-resolution surface sensor) at 0.5 or $1 \mathrm{~cm}$ intervals, and imaged with X-radiography and CT systems. Selected grain size analyses were performed with the laser diffraction method using a Beckman-Coulter LS 
13-320 laser counter (Blott and Pye, 2006). Physical property data may serve as a good proxy for properties of the sedimentary units within the core when verified with ground truth data (Wetzel and Balson, 1992; Weber et al., 1997; Rothwell and Rack, 2006). We primarily use magnetic susceptibility and both gamma and CT derived density as grain size proxies and for stratigraphic correlation, verified by grain size analyses. Further discussion of this proxy and the use of other physical property parameters can be found in Goldfinger et al. (2012).

Correlation between sites was attempted by integrating physical property parameters with core imagery, age data, and CT data and interactively testing alternate correlations and lack of correlation. The procedure used is to match tops and bases of individual beds using all data simultaneously, a procedure known as "flattening". The combined data set from the turbidite sequences are shifted iteratively relative to each other, using "ghost traces" to compare alternative detailed matching of wiggle traces from site to site, similar to e-log correlation in the oil industry (McCubbin, 1982; Lovlie and Van Veen, 1995; Chen et al., 2009). These methods have also been applied in academic research with piston, gravity and ODP/IODP cores (e.g., Fukuma, 1998; Karlin et al., 2004; Abdeldayem et al., 2004; Abrams, 2002; St-Onge et al., 2004; Iwaki et al., 2004; Schnellmann et al., 2002; Goldfinger et al., 2008, 2012).

Stratigraphic interpretation was improved by comparing multiple cores from a single site when possible. Locally, the stratigraphy and its local variability could be well constrained with two or three piston-trigger pairs of cores, and differential basal erosion could be detected and quantified by comparing individual hemipelagic intervals across the core set (Goldfinger et al., 2012; Pastor et al., 2009). This reduced the possibility of correlating an unrepresentative example of a given event, and allowed for improved assessment of basal erosion, missing tops, and core deformation across the core set at each site, commonly providing at least one uneroded and undeformed example of each event. Gamma or CT density and magnetic susceptibility data were typically collected on orthogonal axes relative to a round core on the scanner track. This provides a cross-check that signatures of a given interval are not the result of local 3-D effects within the core.

In addition to correlation of cores in local groupings, we found it possible to correlate unique lithostratigraphic signatures (physical property proxies) of individual turbidites between cores at greater distances, and between isolated sites with no physical connection (Goldfinger et al., 2008, 2012). Cascadia turbidites are typically composed of multiple stacked and truncated fining-upward sequences (Bouma A-C) capped by a fine-grained fining upward tail associated with waning of the turbidity current (Bouma D). The magnetic susceptibility, density, and grain size trends within each event are closely correlated allowing the use of highresolution density and magnetic data as grain size proxies in many cases, though this must be verified with each lithologic suite (Goldfinger et al., 2012). These turbidite "fingerprints" formed the basis of along strike correlations, closely supported by ${ }^{14} \mathrm{C}$ ages as reported extensively in Goldfinger et al. (2012).

In detail, the magnetic susceptibility (MS) signal is associated with terrestrial silt-sized magnetic minerals, though sand is usually present at the turbidite base (see Stupavsky et al., 1976; King et al., 1982). The sand may be non-magnetic quartz grains, so the MS peak does not always precisely correlate with a maximum of grain size. Nevertheless the approximation is reasonable in most cases (using both gamma and CT density with MS reduces this problem). Detailed grain size profiles therefore represent detailed depositional histories of each turbidite for Cascadia lithologies.

\subsection{Age control}

To date the turbidites, we extracted the calcium carbonate shells of planktic foraminifers preserved in the hemipelagic sediment below each turbidite. We sampled below each turbidite because the boundary between the top of the turbidite tail and the hemipelagic sediment can be difficult to identify reliably. Hemipelagic sediment samples were freeze dried, washed in a dilute calgon (sodium hexametaphosphate) solution and sieved through a $63 \mu \mathrm{m}$ stainless steel sieve, and then dried in a warm oven. A minimum of $\sim 1 \mathrm{mg}$ of planktic foraminifers were extracted (many samples identified to species level) for dating. Radiocarbon ages were obtained using accelerator mass spectrometry (AMS) methods. Radiocarbon data, calibrations, erosion and sample corrections and error budgets for each of these corrections are given in Goldfinger et al. (2012, their Appendix 1), with new data from 2009 cores reported in Table S3a and b in the Supplement. Calibration used the IntCal 09 database of Reimer et al. (2009).

The radiocarbon dates are reported with 2-sigma lab error (Stuiver and Polach, 1977). Lab errors with radiocarbon dating are straightforward and based on counting statistics from the laboratory. All dates are calibrated (as described in the next section), with spatially varying reservoir values from Marine (Reimer et al., 2009). We used the age model developed in Goldfinger et al. (2012, their Appendix 1) which allows estimation of turbidite emplacement ages, accounting for reservoir variation, sediment sample thickness, gaps between the sample and turbidite base, and differential erosion (derived when multiple cores at one site exist) in some cases. Using the age model, we also calculated event ages for wellconstrained beds not dated with radiocarbon. We propagated all uncertainties using RMS (root mean square) calculations using estimates of the uncertainties at each step. This calculation included the lab uncertainties, and resulted in the final reported $2 \sigma$ range for each radiocarbon age. 
The fully propagated $2 \sigma$ uncertainty ranges averaged +140 / - 170 calibrated years (calculations given in Goldfinger et al., 2012, their Appendix 1). We also used age models computed from OxCal, a Bayesian Markov chain Monte Carlo calibration and age model software package (Ramsey, 2001). To compute event ages, radiocarbon and hemipelagic ages (as computed with the above described RMS errors) of well-correlated beds are "combined" to estimate depositional ages where the probability density functions (PDFs) of the radiocarbon ages and hemipelagic ages are combined to compute a new probability function for each turbidite, with narrower $2 \sigma$ ranges based on Bayes' theorem. The prior assumption of the Bayesian calculation is that we have correctly correlated the turbidites stratigraphically. OxCal also tests the assumption of coevality (at the resolution of radiocarbon) with several statistical tests ( $\chi^{2}$ and Acomb). All correlated beds with sufficient data to be combined in this way pass these statistical tests. The time series overall passes additional tests of coherence from site to site (Amodel and Aoverall; see Goldfinger et al., 2012, their Appendix 8). These tests are further described in the $\mathrm{OxCal}$ documentation (http://c14.arch.ox.ac.uk/oxcalhelp/hlp_contents.html). Nevertheless, radiocarbon alone cannot distinguish between a closely spaced series of bed emplacements.

Faunal data were collected from planktic sample assemblages and are included and described in Goldfinger et al. (2012; their Appendix 4). The close correspondence between land and marine ages, and across marine sample sites observed in both the Cascadia Basin and along the Northern San Andreas Fault (NSAF) suggests that, overall, neither bioturbation (Wheatcroft, 1992; Smith et al., 1993; Thomson and Weaver, 1994; Thomson et al., 1995) nor basal erosion significantly biases ${ }^{14} \mathrm{C}$ dates. The topic and treatment of of differential basal erosion is discussed in Pastor et al. (2009) and Goldfinger et al. (2012). Analyses of foram test size, species specificity and other potential biases are presented in Goldfinger et al. (2012). Ages presented here are those of Goldfinger et al. (2012) with new ages and sedimentation rates given in Table S3a and b in the Supplement.

Not all intervals were directly datable by this method. As foraminifer abundance is much lower in the latest Holocene (in some cases we found abundances as low as five individuals $/ \mathrm{cm}^{3}$ ), samples representing times younger than $\sim 2000$ cal yr BP were more difficult to date. The total volume of material available was limited by the hemipelagic sediment deposited between turbidites, thus shorter recurrence intervals (in southern Cascadia) also reduced the chances of obtaining one or more successful ${ }^{14} \mathrm{C}$ dates. In the age range of $\sim 2000-300 \mathrm{cal} \mathrm{yr} \mathrm{BP,} \mathrm{it} \mathrm{was} \mathrm{sometimes} \mathrm{nec-}$ essary to combine samples from piston and trigger cores, and rarely, from multiple localized pairs of piston and trigger cores to collect the required minimum of $\sim 1.0 \mathrm{mg}$ carbonate ( 400-600 specimens) for a successful date. In some cases, we collected multiple cores and a jumbo kasten or box core for this purpose in anticipation of dating difficulties. Mixing in this way requires perfect correlation between the local core sets, though when done incorrectly, incongruous ages were the result.

In several cases in the Barkley, Rogue, Trinidad, Smith, and Klamath systems, we dated benthic foraminifers where planktic foraminifers were not abundant enough to obtain a result. These dates were calibrated using the additional reservoir difference between benthic and planktic samples established locally for those cores for a given time range. This method is similar to that used to establish the modern reservoir value (for example, Hughen et al., 2004). The methods and reservoir model used for these calculations is included in Goldfinger et al. (2012).

Determination of the turbidite tail-hemipelagic boundary and recognition of mud turbidites is uniquely difficult and something that visual and geophysical core logging may not detect in every case. The subtle differences between the very fine-grained turbidites and the overlying hemipelagic sediment may be nearly non-existent, and thus finding techniques to identify the boundary can be difficult. In the case of Cascadia cores, most of these boundaries are visible to the eye as a color change (see figures in Goldfinger et al., 2012). This color difference, which is due to biogenic $\mathrm{CaCO}_{3}$ content, renders the hemipelagic sediment a light tan color, whereas the turbidite tail is olive green (Lyle et al., 1999). For more proximal and southerly sites, this distinction diminishes, becoming subtle.

Many attempts have been made to find universal methods for defining this boundary including clay fabric orientation (O'Brien et al., 1980; Azmon, 1981), color (Rogerson et al., 2006), hydraulic sorting of microfossils (for example Brunner and Ledbetter, 1987), X-ray fluorescence (XRF) and Xray diffraction (XRD) (for example Bernd et al., 2002), and grain size (the most common method; Brunner and Ledbetter, 1987; Joseph et al., 1998; St.-Onge et al., 2004), resistivity, and other methods. While these methods can work in specific cases, there is no universally applicable technique. Additionally, many methods are limited to small numbers of samples, and precluded for this study by logistics of hundreds of the samples used.

We determined hemipelagic thickness and mud turbidite boundaries using primarily visual observations of color change, X-radiography and CT imagery, and high-resolution physical property data (see Goldfinger et al., 2012), augmented with smear-slide photomicrograph transects across key boundaries where required. High-resolution gamma density, point magnetics and CT imagery proved the most sensitive and reliable, acting as proxies for grain size as previously described, however this method must be verified for applicability with specific lithologies. In ideal cases, both density and magnetic susceptibility values declined upward in the fining upward tail, and reached an inflection point at which constant values continued upward to the base of the overlying turbidite, reflecting a homogenous uniform grain size and lithology in the hemipelagic sediment. The density 
and susceptibility curves were verified by grain size analyses to confirm this relationship. In numerous examples, many hemipelagic-tail boundaries could be accurately identified by this method, which was corroborated with color change observations for most cores. The primary difficulty with this method proved to be bioturbation, which blurs the tail boundary, an effect that was evident in the physical property and CT data. Using grain size analysis directly was not always diagnostic and was practically limited by the large numbers of samples required for regional analysis of many cores. Grain size transects across key problematic boundaries were run with a Beckman-Coulter LS 13-320 laser diffraction particle size analyzer (Blott and Pye, 2006). Combined with smear-slide grain counts for lithic and biogenic components a good result could be obtained, though silicious biogenic fragments sometimes were larger than the lithic component in hemipelagic sediment, and therefore generated somewhat noisy results.

\subsection{Seismic reflection imaging}

We collected $\sim 11000 \mathrm{~km}$ of continuous shallow seismic reflection profiles along the length of the Cascadia margin in 1999, 2002, 2009, and 2011 using a Knudsen 320BR and Knudsen $32603.5 \mathrm{kHz}$ system (FM Chirp mode sweeping 2$6 \mathrm{kHz})$ at full bandwidth and data rate. Our primary lines are a pair of mostly continuous margin parallel lines averaging $\sim 2.5 \mathrm{~km}$ apart located $\sim 0-5 \mathrm{~km}$ seaward of the deformation front (Fig. 1). There are several cross lines at intervals along strike including several lines across the Rogue apron that link the core sites with the regional margin parallel reflection profiles. These lines were heave corrected in real time using the ship's Pos MV 320. We post-processed the data using Sioseis (http://sioseis.ucsd.edu/sioseis.html; Henkart, 2006) using band pass filtering, muting, and a heave filtering algorithm. Further processing, including Hilbert transform, and interpretation were done in IHS Kingdom v. 8.71. Digital correlation processing of the Chirp signal reduces the effective frequency, improving the signal to noise ratio and boosting the effective vertical resolution to $\sim 25 \mathrm{~cm}$, degraded somewhat by off-axis scatterers, vessel motion and the water column.

We generated synthetic seismic section velocity models in IHS Kingdom based on the physical data from local cores through which the seismic tracklines passed. We applied a velocity model to attempt to put the core data and reflection data on a common vertical scale. We generated a velocity model using the $P$ wave velocity data from the cores, and by converting gamma density to $P$ wave velocity (Hamilton, 1970; modified by Brocher, 2005). These models produced similar and consistent results, allowing a robust correlation between the cores and seismic sections.

\section{Background-mud turbidites along the southern Cascadia margin}

Goldfinger et al. (2012) describe 41 turbidites along the southern Cascadia margin, (exclusive of the southernmost margin from Trinidad Canyon to the southern limit at the Mendocino Triple Junction) exemplified by cores located in Hydrate Ridge west basin, and the Rogue Apron. We briefly summarize the structural and physiographic contexts, and the Holocene stratigraphic records with particular emphasis at these two sites, and refer the reader to Goldfinger et al. (2012) for further details of other regional sites. Bed numbers (i.e., $\mathrm{T} 1, \mathrm{~T} 2$, etc.) referred to in this paper and in Goldfinger et al. (2012) were assigned following correlation between multiple sites. Local bed names are used at sea and in initial work that may appear in core logs and other ancillary data, and may differ from those assigned after correlation and reported here.

\subsection{Hydrate Ridge west basin}

Hydrate Ridge west basin (referred to herein as Hydrate Ridge or HR) is a piggyback basin west of a composite thrust ridge formed from seaward and landward vergent thrust faults (Johnson, 2004) within the lower slope of the Cascadia accretionary wedge on the central Oregon continental margin (Fig. 2a). HR is also flanked on the east by another piggyback slope basin. The isolation of the western slope basin from any canyon or channel system limits basin filling to local submarine slope failures of the surrounding bathymetric highs (Hydrate Ridge itself) and hemipelagic sedimentation. The largest sediment-transport pathway into the basin is a small submarine canyon that cuts into the western flank of northern Hydrate Ridge; however, several other smaller potential pathways internal to the basin exist around the basin from the north and east. The face of the west flank of Hydrate Ridge is primarily exposed east dipping poorly consolidated sand and silt turbidites recently uplifted by the seaward vergent thrust that underlies Hydrate Ridge (Johnson, 2004, L. D. Kulm, unpublished ALVIN dive data). The Hydrate Ridge core sites are isolated from all terrestrial and shallow water sediment sources by sill heights on three sides with a minimum height of $\sim 500 \mathrm{~m}$ at a low point in the surrounding ridge to the NE. There are no observed channels in the region and no significant fluvial or other sediment sources onshore for terrestrial material. The shallowest point at the top of the ridge is $-600 \mathrm{~m}$, well below disturbance levels for even the largest storm or tsunami waves (see analysis and Fig. 30 of Goldfinger et al., 2012). The isolation of the basin thus provides an environment in which the local physiography has excluded storm loading, hyperpycnal flow, cross-shelf transport, tsunami wave loading and other shallow-water origins for the observed turbidite stratigraphy. 

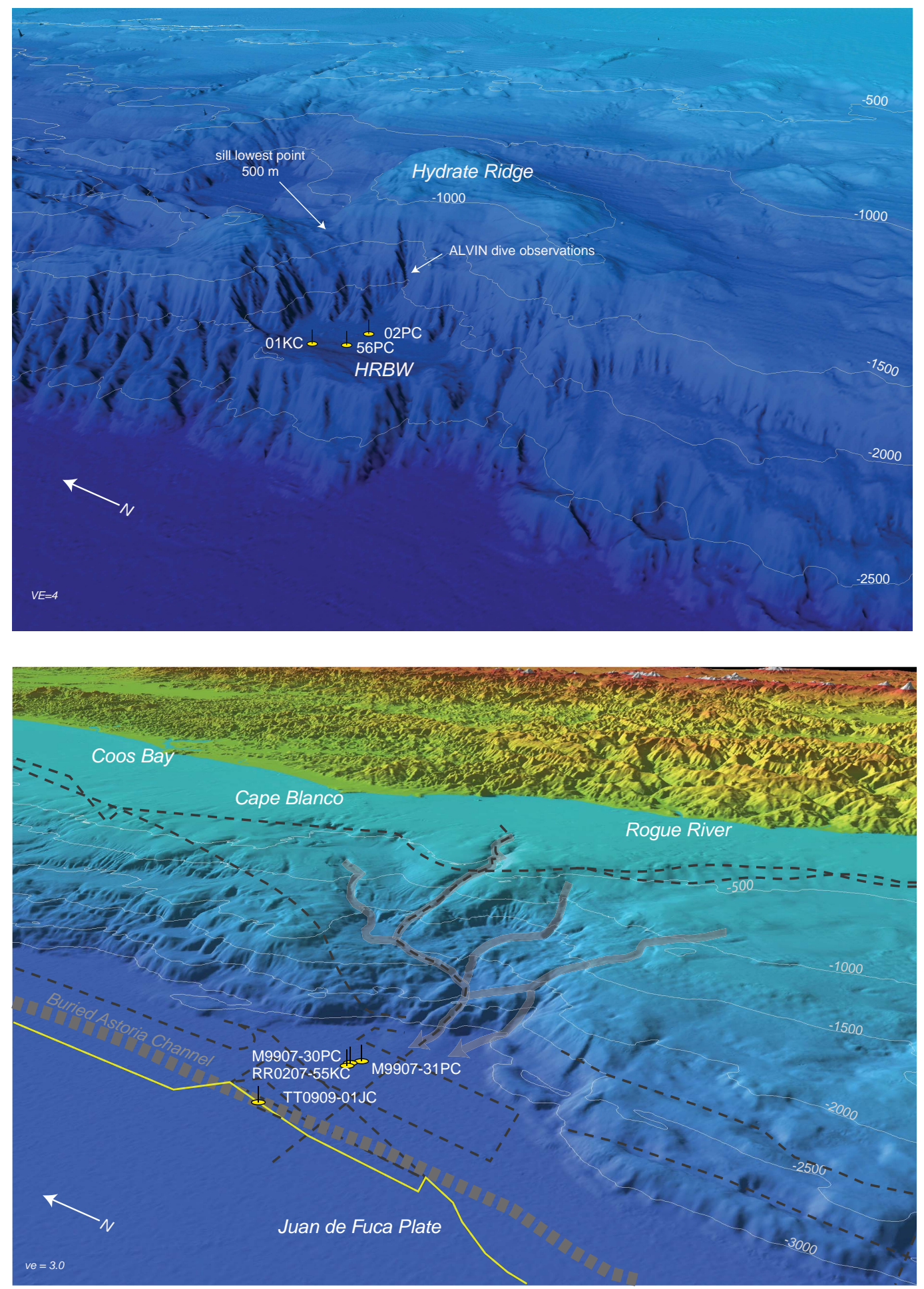

Fig. 2. (A) Shaded perspective view of Hydrate Ridge west basin (HRWB) on the central Oregon margin. The basin is protected on all sides from terrestrial sediment input by structural sills with heights of $\sim 500 \mathrm{~m}$ to the north, $1800 \mathrm{~m}$ to the east, and $1200 \mathrm{~m}$ in the south. (B) Perspective shaded view of bathymetry of the Rogue Canyon system and apron, southern Oregon margin. Multiple canyon tributary pathways are shaded grey. No topographic expression of a channel leading from the Rogue Canyon is apparent at the resolution of the multibeam bathymetry. Similarly, the buried Astoria Channel (foreground) has no bathymetric expression at this latitude. The $3.5 \mathrm{kHz}$ reflection tracklines shown. Lines shown in Figs. 9 and 10 are indicated in yellow. Inset shows approximate a and b locations with yellow boxes. 


\subsubsection{Hydrate Ridge (west basin) turbidite sequence}

Three core sites in the Hydrate Ridge basin are located at variable distances west of the submarine canyon cut into the western flank of Hydrate Ridge (Fig. 2a; see also Goldfinger et al., 2012, their Fig. 30). The most proximal (furthest east) site to the canyon contains a highly expanded late Holocene $(\sim 3000 \mathrm{yr}$ ago to modern) record in cores RR0207-02PC/TC. The mid-basin site to the west (RR0207-56PC/TC) contains a complete Holocene record. The Holocene section in distal kasten core RR0207-01KC is too compressed for further use in this study. Excess ${ }^{210} \mathrm{~Pb}$ activity in the core tops confirms the preservation of the uppermost section. No transported (or airfall) Mazama ash (Zdanowicz et al., 1999) is present in any of the Hydrate Ridge cores, supporting the inference of isolation of the Hydrate Ridge site from fluvial sources. The Hydrate Ridge cores exhibit some of the best resolution of individual turbidite beds among our cores. This is partly due to overall section expansion attributable to the extremely proximal location of the core sites relative to the ridge flanks. Expansion of the section is only part of the difference however, since the HR Holocene section is only $6.6 \%$ greater in thickness at HR at $730 \mathrm{~cm}$, than Rogue Apron at $685 \mathrm{~cm}$. A perhaps better explanation is the very short transport distance and time during transport for distinct inputs to mix following the initiating event. The limited mixing time may allow individual sediment pulses during the upslope failure to remain more distinct than at more distal sites (Goldfinger et al., 2007, 2011). There is one example of an overlying thick turbidite unit having eroded into an underlying thin one, where the uppermost turbidite (correlated as regional event T1) is eroded into the underlying bed (T2) in RR0207-02PC/TC (see also Goldfinger et al., 2012). This scenario appears to be rare in our cores, and may sometimes be identified by using multiple cores. With enough replicate cores, one of them is likely to reveal the presence of hemipelagic sediment that is eroded in others, if it was originally present.

Radiocarbon ages and stratigraphic correlation suggest that the Hydrate Ridge turbidite stratigraphy correlates well to other Cascadia sites with only one notable exception. We note that correlated regional bed T14 is either missing or very weakly expressed in Hydrate Ridge cores pfor reasons unknown. The HR stratigraphic record differs from other Cascadia sites further north by the presence of twelve thin mudsilt beds we observe in all Hydrate Ridge cores, but closely resembles Rogue Apron cores. These thinner beds are indicated by density and magnetic excursions, X-radiography and CT data, and color reflectance data (Figs. 3, 4). All Hydrate Ridge cores contain a relatively high silt content that we find disseminated throughout even the hemipelagic beds, making the distinction of mud turbidites more difficult. We attribute this to the steep, sandy cliffs exposed immediately upslope by seaward vergent thrust faulting. We suggest these non-cohesive cliffs input a steady rain of silty-sandy material to the proximal basin floor, and observe a similar phenomenon in cores from Sumatran slope basins (Patton et al., 2009, 2013).

\subsection{Rogue Canyon and Apron}

The Rogue Canyon traverses the continental slope off the mouth of the Rogue River in southern Oregon as a welldeveloped submarine canyon with multiple tributaries funneling into two unequal outlets at the apex of Rogue Apron (Fig. 2b). A morphologic apron of about 5-10 $\mathrm{m}$ in thickness and $2 \mathrm{~km}$ diameter extends from the canyon mouth, which otherwise does not have an observable outlet channel system at the resolution of existing bathymetric and backscatter data (11 m backscatter grid from cruise TN240) and $3.5 \mathrm{kHz}$ high resolution sub-bottom profiles. This geometry, lack of significant channel development, and the presence of turbidites containing Klamath terrane heavy minerals (Goldfinger et al., 2012) all support the interpretation of a small sand-rich, base-of-slope apron developed off the mouth of the Rogue Canyon and supplied by sediment from the Rogue River drainage. The Rogue Canyon system has three major tributaries that cross the steep continental slope and converge near the canyon mouth. The Rogue River supplies the southern of these tributaries, the other two do not have modern river analogs, but may also receive transported material from the Rogue system under conditions of storm transport from southwesterly storm wind and wave regimes.

\subsubsection{Rogue Apron turbidite sequence}

$3.5 \mathrm{kHz}$ profiles, core stratigraphy, turbidite bed lithology and radiocarbon ages all suggest that lateral-bed continuity is present throughout the Rogue Apron (Figs. 3, 4; Goldfinger et al., 2012). The Rogue Apron turbidite record includes the Mazama ash, which anchors the stratigraphic sequence. The stratigraphy is correlative between the eight cores at this site. Mazama ash is present in all Rogue Apron cores. Goldfinger et al. (2012) report the discovery that the first Mazama ash-bearing turbidite likely was not margin-wide T13 as reported earlier. Based on stratigraphic correlation and ${ }^{14} \mathrm{C} \mathrm{ev}-$ idence, the Mazama ash appears first in regional event T14. The proposed explanation for this anomaly is given in detail in Goldfinger et al. (2012).

The Rogue Apron contains, in addition to the thick turbidites discussed by Adams (1990) and Goldfinger et al. (2003a,b, 2008, 2012), 23 (modified here from Goldfinger et al., 2012) mostly thinner silt/mud turbidites that reflect a higher turbidite frequency that is prevalent in all our southern Cascadia cores.

Two of these, now known as T10b and T10f, are sandy beds that are similar to coarse-grained regionally correlated turbidites. An additional 21 beds are mostly thinner mudsilt beds that originally were noted as darker intervals in what otherwise was thought to be hemipelagic sediment in 


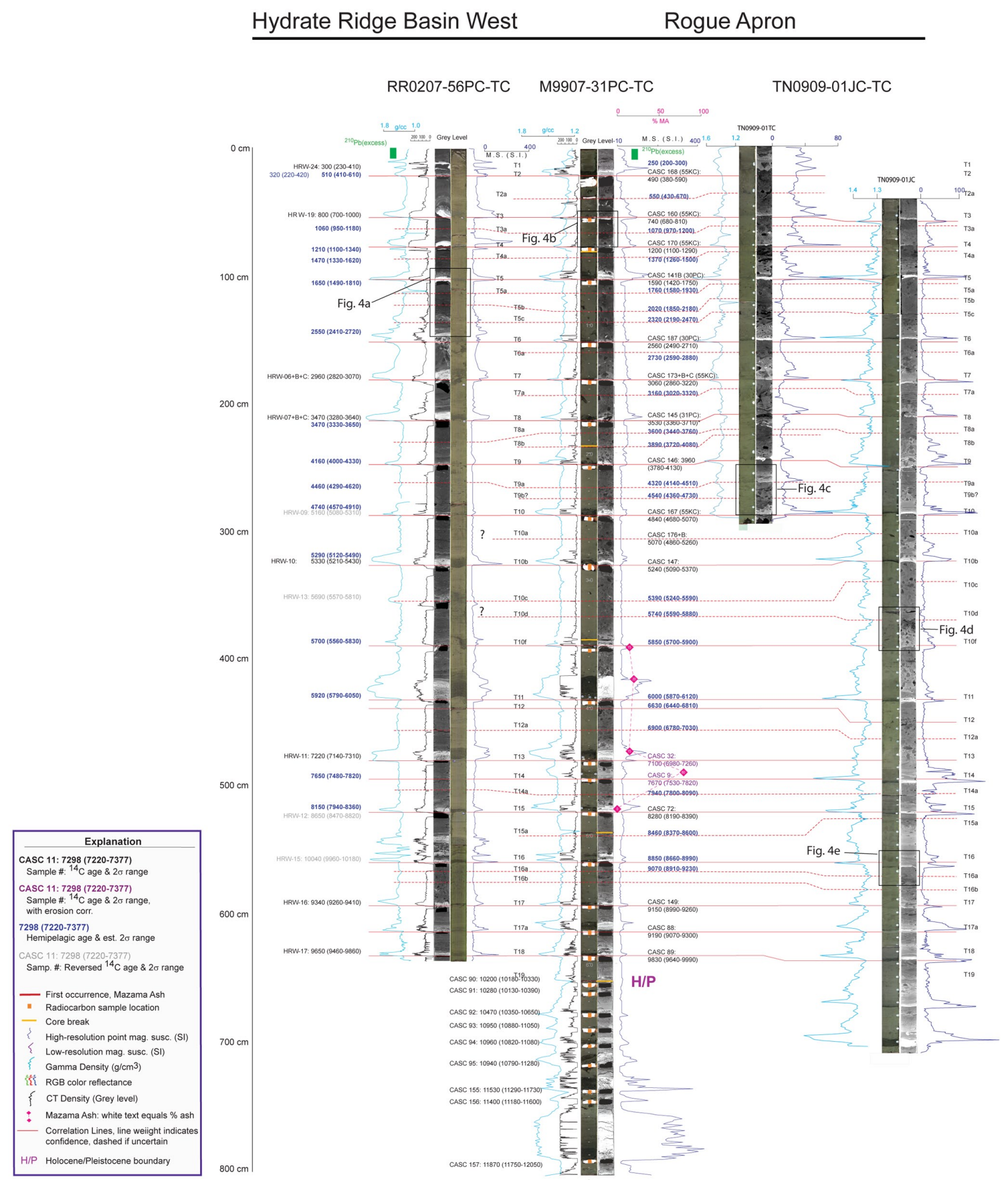

Fig. 3. CT, visible imagery and physical properties from the Hydrate Ridge and Rogue Apron cores, central-southern Cascadia margin. Data from HR cores 56 PC-TC and Rogue cores 31PC-TC are each summarized with a single composite of piston and trigger cores, all ${ }^{14} \mathrm{C}$ ages from each site are plotted on the representative core. These two cores are "flattened" (rescaled with event bases and tops aligned) with Rogue core 31PC at true scale. Undated Rogue Apron core TT0909-01JC also shown flattened to 31 PC-TC. Correlation between sites based on stratigraphic methods described in text, ${ }^{14} \mathrm{C}$ data, Mazama ash and Holocene/Pleistocene boundary datums. Black boxes indicate locations of enhanced images in Fig. 4. Higher confidence shown by heavy lines, lower confidence with dashed lines, lowest confidence with queried dashed lines. The two sites are $250 \mathrm{~km}$ apart and are isolated from each other. Hydrate Ridge is isolated from terrestrial and shallow water sediment sources. 


\section{Hydrate Ridge Basin West}

\section{Rogue Apron}

Rogue Apron
A.

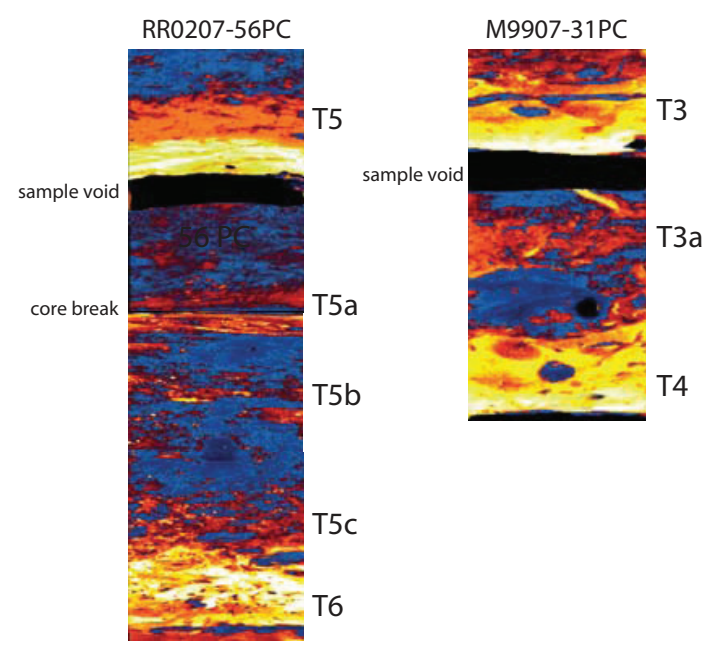

C.
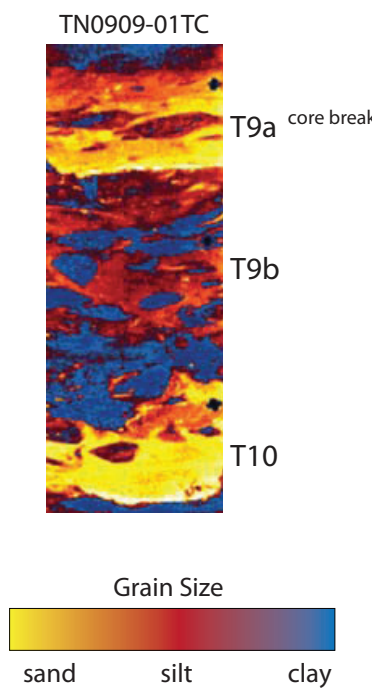

D.

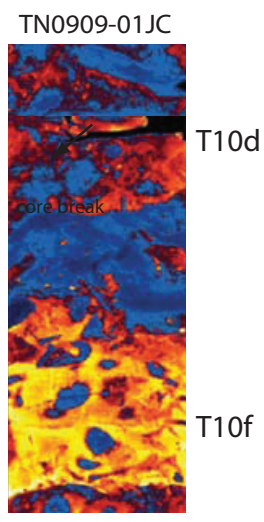

clay

Fig. 4. Enhanced CT imagery shown for representative thin turbidites in at Hydrate Ridge and Rogue Apron. CT imagery shown in context in Fig. 3. CT density imagery processed to show approximate sand and silt (orange and yellow); fine silt (orange) and hemipelagic mud (blue). Approximate grain size key shown at bottom. Some units show typical structure such as cross bedding (T5a, T9a, upper and middle left panels), while others have largely lost primary structure due to bioturbation (T9d, T10d) (modified after Goldfinger et al., 2012).

the shipboard logs of the 1999 cores. However, further examination revealed that these dark intervals sometimes had silty bases, noted in the original logs, and that they were in consistent stratigraphic position across multiple cores. These beds have density and magnetic peaks in physicalproperty logs, as well as being imaged as dense bodies in $\mathrm{X}$-radiographs and CT imagery (Figs. 3-8). The originally logged hemipelagic intervals furthermore appeared far too thick for reasonable sedimentation rates, and thus were likely not uniform hemipelagites. Goldfinger et al. (2012) and this paper retain the original 18 turbidite numbers published previously to maintain consistency with earlier publications and to distinguish those turbidites with long strike extent vs. the thinner beds of more limited extent. The thinner turbidites in southern Cascadia are designated using the overlying bed number (for example T5a for a thin bed between T5 and T6). Some of these fine-grained beds are not presently datable by ${ }^{14} \mathrm{C}$ methods because there is either not enough hemipelagic material available in the thin intervals below them, or the bioturbation that commonly disrupts the smaller beds makes definition of top and bottom boundaries too irregular and the sample content too uncertain in some cases.

\section{Results: character and continuity of the southern Cascadia mud turbidites}

\subsection{Sedimentology and biostratigraphy}

We observe two classes of thinner turbidite beds at Rogue Apron, where they were first documented: a thicker class and a thinner class. The thicker class includes two sandy beds T10b and T10f (Figs. 3-8) both of which have well-defined sharp and possibly erosional sandy bases, and fining upward sequences. The smaller class of southern Cascadia turbidites, 21 in all, is comprised of a series of thinner mud-silt beds. These beds are characterized by more subtle grain-size variation and visual color change, subdued physical-property signatures, and greater bioturbation. Otherwise, they are similar to the coarser turbidites in that they are relatively barren of microfossils, have internal structure including cross bedding visible in CT imagery, have high lithic content, and persist across multiple cores at a given site. The initial interpretation of these beds, including the thinner beds in the range 0-3000 cal yr BP, is given by Goldfinger et al. (2008), and extended to $10000 \mathrm{yr}$ in Goldfinger et al. (2012). The origin of the darker intervals was initially unknown; however, the physical property, color, smear slide, grain-size, and CT data were later interpreted to be consistent with fine-grained mud turbidites in Goldfinger et al. (2008, 2012). 
Of the 21 mud-silt beds found in the Rogue Holocene core stratigraphy, most are defined by characteristics analogous to those of the macroscopic turbidites, though with grain size profiles of reduced amplitude, while some of them are coarse enough to be observed visually. At the Rogue Apron site, the younger 13 beds are each sampled in seven cores; the lower 9 beds are each sampled in three cores (the shorter trigger cores are only $3.04 \mathrm{~m}$ in maximum length). The primary characteristics of these beds are grain size profiles that commonly indicate a sharp base and fining upward sequence based on gamma and CT density and magnetic susceptibility grain size proxies (Goldfinger et al., 2012; Figs. 3-7). Of the 21 beds, 17 of them have these dominant characteristics. The remaining six beds at Rogue Apron (T7a, T8b, T9b, T12a, T16a, T16b) are equivocal or indeterminate due to bioturbation, core section breaks, sample voids from earlier work, core deformation or are indistinct. There are no beds that have clearly coarsening upward, or coarsening upward then fining upward profiles. Of the 21 beds, all of them are visible in at least one core as darker beds in comparison to lighter toned hemipelagic sediment above and below. Eight of them reach sand or silt size at their bases in at least one core at the Rogue site (T2a, T3a, T8a, T9a, T10a, T10b, T10d, and T10f) and four at Hydrate Ridge (T5c, T10b, T10c, and T10f), see Table 1.

In cores south of Rogue Apron (Smith and Klamath sites) beds in the time range $\sim 500-3400 \mathrm{cal}$ yr BP are finer grained and more homogenous, possibly due to reduced sedimentation rates or more dilute sources. Before that time, from $\sim 3400$ cal yr BP to the earliest Holocene, the cores reveal an expanded section of much higher resolution. Density and basal grain size progressively increase southward for the Holocene's thin beds (as excepted above).

\subsubsection{Source of the thin beds at Rogue Apron}

In Fig. 5, we show the upper part of 2009 core TN090901JCTC. Bed T2a in this more distal core is shown in detail. This typical bed shows the shift from dominant biogenic material in the surrounding hemipelagic sediment to lithic fragments. The biogenic material included in the tail of this typical bed is rich in glass sponge spicules, making up as much as $50 \%$ of the turbidite tail in some samples. The glass sponges generally live at depth ranges of 150 $1300 \mathrm{~m}$ (Bett and Rice, 1992; Tunnicliffe et al., 2008). These sponges have been observed at several Cascadia canyon heads, notably Grays Canyon, on flat plateaus flanking the canyon rim (P. Johnson and E. Clarke, unpublished data). The Rogue Apron cores are all at depths of $\sim 3100 \mathrm{~m}$, far deeper than the sponge habitat, and therefore the spicules were likely transported to the Rogue Apron from upperto mid-slope depths by turbidity currents. Abundant sponge spicules have also been observed in turbidite tails in Astoria Canyon turbidites (Nelson, 1968). Similarly, displaced shallow water benthic foraminiferal species (Bolivina seminuda,
Buliminella elegantissima, Cassidulina limbata, Cassidulina minuta and Globobulimina auriculata) as well as wood and plant fragments and broken mollusk shells have previously been described in Holocene turbidites in Washington margin cores (Carson, 1971; Barnard, 1973). Nelson (1968) described in detail displaced Oregon shelf and slope species of benthic foraminifera in the Holocene turbidites of Astoria Canyon. Modern sediment loading of the upper canyons with shelf derived sediment has been described by Thorbjarnarson et al. (1986) and discussed further in Goldfinger et al. (2012, and references therein).

We also observe that the lighter toned hemipelagic sediment that bounds the darker mud-silt beds has significantly lower occurrence of lithic fragments, and higher occurrence of intact radiolarians, including delicate forms, and both benthic and planktic forams, all of which are relatively rare in the mud beds. When present in the mud beds, the larger fragile forms of radiolaria are typically fragmented or represented by small shards indicative of transport (Figs. 5, 6). Figure 6 shows similar data for Rogue mud turbidite T5b.

The mean grain size profiles across the mud turbidites for which data are available are not always diagnostic of sharpbased fining upward turbidites, probably due to the biogenic material included in the samples. Grain size sometimes actually increases slightly in the hemipelagic beds because the biogenic components are actually larger in most cases than the lithic matrix of the turbidite tails. Figure 5 shows grain size profiles broken out by size fraction and in aggregate across typical mud turbidite T2a at Rogue Apron. The erratic results in the hemipelagic intervals are due to the patchy biogenic components in the samples. We also show a lithic grain-size profile determined from microscopy for comparison.

\subsection{Regional lithostratigraphic and temporal correlation}

\subsubsection{Hydrate Ridge to Rogue Apron}

In Fig. 3, we show Rogue cores M9907-31PC-TC and TN0909-01JC-TC alongside Hydrate Ridge cores 56 PCTC. Both sites have good radiocarbon age control, and hemipelagic age model determinations for most beds without ${ }^{14} \mathrm{C}$ control. The Hydrate Ridge core has been "flattened" to the Rogue cores, meaning tops and bases of major turbidite beds are aligned for visual inspection. Hydrate Ridge is isolated from land sediment sources, and thus no Mazama ash would be expected in turbidite beds there, and indeed none is observed (Goldfinger et al., 2012). We compare the radiocarbon age series and lithostratigraphy of the turbidite sequences for differences and/or similarities. 


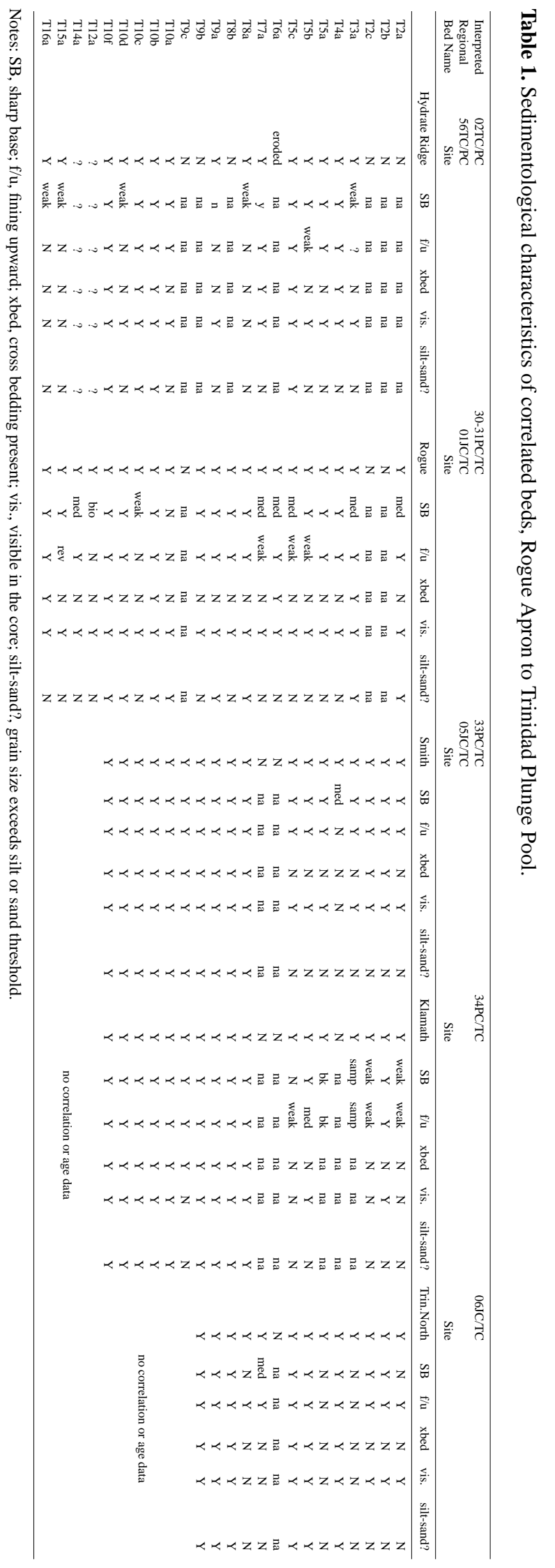



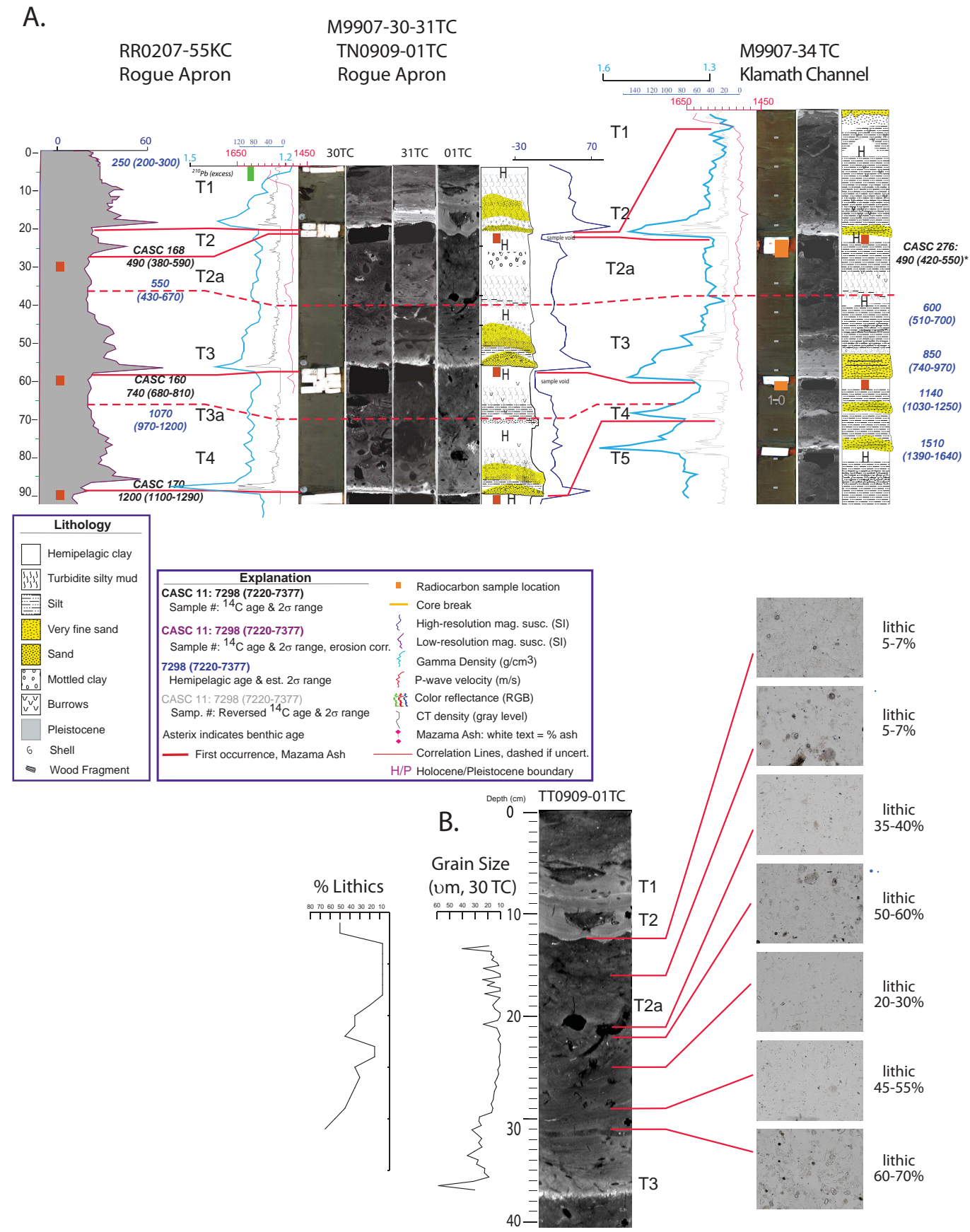

Fig. 5. (A) Details of events from the surface to T4, Rogue Apron and Klamath Channel, emphasizing small events T2a and T3a. Detailed magnetic susceptibility, gamma density and $P$ wave velocity records and CT imagery reveal fine-grained mud turbidites between T2 and T3, and T3 and T4, which were originally logged as "dark" clay. Lithologic detail is summarized from cores 55KC, 30TC, 31TC, TT090901TC (Rogue), and 34TC (Klamath). Hemipelagic ages and ranges are calculated from the age model using hemipelagic thickness, and sedimentation rates and ${ }^{14} \mathrm{C}$. T1 has apparently eroded into T2 in core 30PC (center) but remains distinct in the Kasten core (left) and in 34TC with hemipelagic sediment between them. CT imagery for both 30 and 31TC, and 01TC are shown for comparison, this imagery is "flattened" on major horizons in 30TC. (B) Detail of CT and smear-slide data from core TN0909-01TC. Smear slides taken in a transect across T2a show the lithic content from hemipelagic material consisting of $\sim 30 \%$ clay, $5-7 \%$ lithics, and $\sim 65 \%$ biogenic material. T2a is $50-60 \%$ lithic, the thin bioturbated interval of hemipelagic sediment below is $20-30 \%$ lithic, and the tail of T3 is $30-70 \%$ lithics. The biogenic material in the tail of $\mathrm{T} 2 \mathrm{a}$ is rich in heterogeneous patches of glass sponge spicules transported from shallower water. The grain size plot across T2a in M990730TC is shown and "flattened" to the lithology in 01TC in (B). 

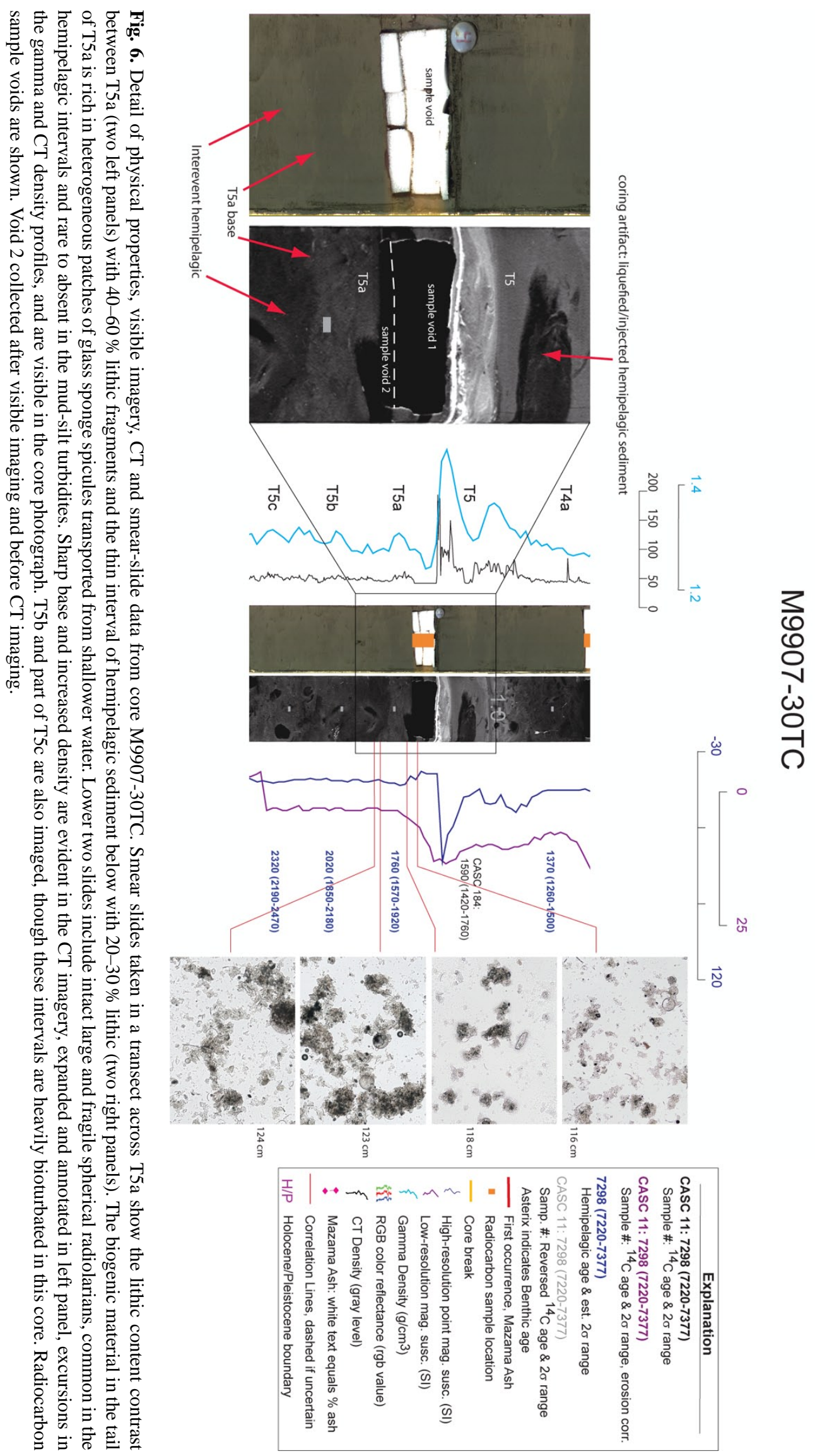
Inspection of the median and $2 \sigma$ ranges for age series at both sites indicates that the number and approximate ages of the sandy turbidites at both sites are similar. Statistical results show that the $\chi^{2}$ and OxCal Acombine and Amodel tests (Ramsey, 2001) of synchronous deposition are passed to at least the $95 \%$ confidence level for all beds in Fig. 3 with either radiocarbon or hemipelagic age control (Goldfinger et al., 2012). The same is true of larger margin-wide temporal correlations of 19 correlated Holocene beds. These tests indicate age compatibility to the indicated level, but within radiocarbon uncertainties. Goldfinger et al. (2012) present results for both Bayesian combination of potentially correlative beds, as well as the narrowing of the uncertainty ranges that result from statistically meaningful correlations.

The age model for Hydrate Ridge is anchored by ${ }^{14} \mathrm{C}$ ages for HR beds T1, T3, T7, T8, T10b, T13, T17, and T18. Beds T10, T10c, T15 and T16 had badly reversed ages and were not included in the model. Hemipelagic (model) ages were then calculated for beds with sufficient age and hemipelagic thickness control, and include T2, T3a, T4, T5, T6, T8a, T9, T9a, T10b, T10f, T11, T14, T15, T16, and T17a. The Rogue site age model is anchored by ${ }^{14} \mathrm{C}$ ages for 15 of 19 major Rogue beds except T1, T11, T12 and T16. Hemipelagic ages are calculated from the model for all other beds. Of the thinner beds not correlated margin-wide by Goldfinger et al. (2012), the thickest of them, known at both sites as T10b and T10f have concordant ${ }^{14} \mathrm{C}$ dates for T10b in core M9907$31 \mathrm{PC}$ that are $5240(5090-5370) \mathrm{cal}$ yr BP and 5220 (50705350) cal yr BP. The ${ }^{14} \mathrm{C}$ age of the potential correlative bed in HR core RR0207-56PC has a median age of 5330 (52105430) cal yr BP and has a compatible calculated hemipelagic age of 5290 (5120-5490) cal yr BP. T10f is not radiocarbon dated at any site, but has a calculated hemipelagic age of 5850 (5700-5900) cal yr BP in the Rogue cores, and 5700 (5560-5830) cal yr BP at Hydrate Ridge.

CT imagery, physical property traces and age control are presented in Fig. 3 for visual inspection. We interpret similarities in turbidite structure between the two sites (grain size profiles as indicated by density and magnetic proxies) that permit correlations between the two sites for many of the beds when considered with supporting age control. Goldfinger et al. (2012) present statistical tests of the downcore core series of turbidite mass and number of fining upward sequences for the entire Holocene sequence that show similarities that suggest the sequence is coherent in both event "size" and first order bed structure of these stacked turbidites. Our lithostratigraphic correlations between beds are based on these criteria and shown in Fig. 3. Of the 42 beds observed at Rogue Apron, Goldfinger et al. (2012) conclude that, assuming the correlation is substantially correct, 7 of them are likely not observed at Hydrate Ridge (Fig. 3). Our analysis with improved data from Rogue Apron leaves this conclusion unaltered. Several of the thin beds interpreted to be present at both sites are quite weak at Hydrate Ridge, including beds T8a and T9a, which are equivocal.

\subsubsection{Rogue Apron to Trinidad Plunge Pool}

New cores collected in 2009 have, along with Chirp reflection profiles, offered additional data with which to evaluate continuity of turbidite beds southward from Rogue Apron beyond the interpretation presented in Goldfinger et al. (2012). Bed correlation along this section of the margin proved to be more robust than previously reported due to the increased spatial density of cores, additional age control and stratigraphic constrains provided by high-resolution Chirp reflection profiles.

The new cores in the Rogue-Trinidad section of the proximal abyssal plain include six piston-trigger core pairs and one kasten core, 13 cores in all. These cores are TN0909 01, 02, 04, 05, 06, and 07 JC-TC, and 03KC (a new designation "jumbo core" is used for post 2007 cores, but these are identical piston cores designated "PC" in earlier publications) (see Fig. 1 for locations). We focus on the better of these cores, 01, 02, 05, 06, and $07 \mathrm{JC} / \mathrm{TC}$ (cores 03KC and $04 \mathrm{JC}$ each have a missing section, heavy bioturbation, or core deformation). Additional cores south of Trinidad Plunge pool are more difficult to correlate stratigraphically, have limited age control, and are not included in the preliminary results reported here. Cores inside the Trinidad Plunge Pool, reported in Goldfinger et al. (2012) are somewhat less straightforward than the newer cores presented here. Older than $\sim 800$ cal yr BP, the plunge pool cores are well correlated to those outside the plunge pool. From 0-800 cal yr BP, numerous beds are present in the plunge pool section that are not found outside the plunge pool, a discordance that remains unexplained.

Generally, cores 01-06 PC TC all contain clear and distinct turbidite sequences. Core $01 \mathrm{JC} / \mathrm{TC}$, located $5 \mathrm{~km}$ seaward of our original 1999 cores on Rogue Apron, correlates directly to those cores with little variation. This new core offers improved definition of the Rogue stratigraphy, as CT data was collected for this core prior to any sampling. The oldest regional event in the Holocene turbidite section correlated in Goldfinger et al. (2012), like the earlier cores, is marked by regional event $\mathrm{T} 18$, the base of which is found at $780 \mathrm{~cm}$ below the core top. The same bed in the more proximal M9907-30 and 31PC/TC is found at $635 \mathrm{~cm}$, indicating a $\sim 20 \%$ seaward thickening of the Holocene section. We attribute this to a greater capture of the middle grain sizes of the turbidite in the more distal cores. The more proximal cores exhibit significant bypassing of the middle grain sizes (Kneller and Buckee, 2000; Stevenson et al., 2012) at those sites based on common sharp upper contacts between the coarse-grained phases and the fine-grained turbidite tail. These gaps in grain size distribution are less apparent or absent at the more distal $01 \mathrm{JC} / \mathrm{TC}$ site, likely making up the thickness difference between the two sites.

Moving southward, new cores TN0909 02 and 05 JC/TC and $03 \mathrm{KC}$, along with older cores M9907 33PC and M990734 PC, are located along a part of the margin fed 

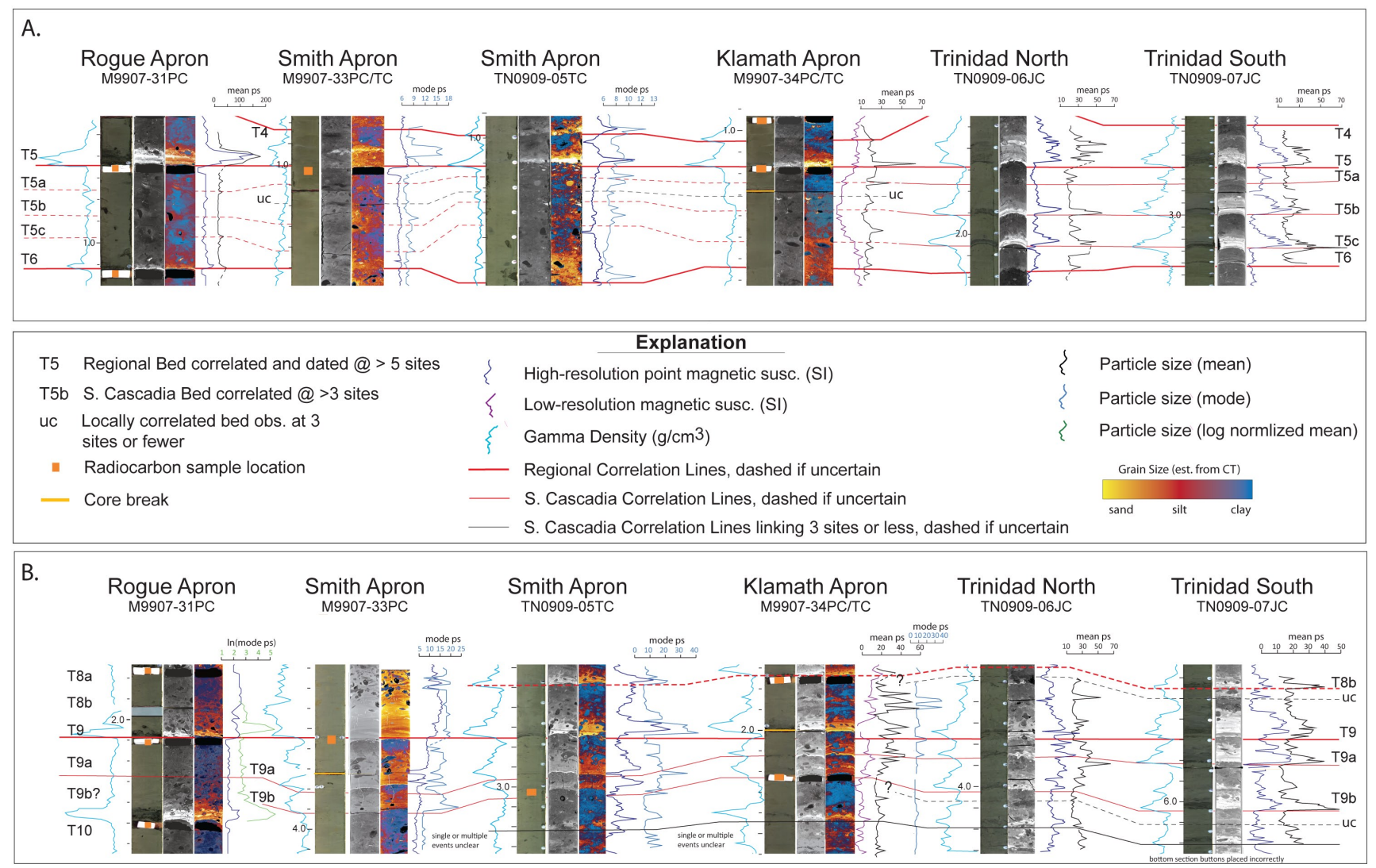

Fig. 7. (A) Detailed physical property and CT data from correlated events T5, T5a, T5b, and T5c in a transect from Rogue Apron to the Trinidad Plunge Pool, flattened to regional event T5. This transect shows the southward increase in thickness, density and grain size for regional event T5 and three southern Cascadia beds (T5a-c). (B) A similar transect for events interpreted as T9, T9a, and T9b. Examples are approximately flattened to correlated event T9, shown by heavy red line. These data are shown in context in Fig. 8. Mean grain size shown for cores with sandier turbidites and large contrast between turbidites and hemipelagic. Grain size mode shown for Smith and Klamath apron cores, which have poorly developed channel systems, and reduced average grain size profiles. Mean and mode shown for 34PC for comparison. In these cores, the grain-size variation is commonly dominated by large biogenic forms. Log-transformed grain size data shown in green for $31 \mathrm{PC}$, which has the finest grain size profile for the Rogue mud turbidites. See Fig. 1 for core locations. Age control, and density and magnetic scales shown in Fig. 8.

only by smaller or no canyon systems. Perhaps not coincidentally, the turbidite beds have reduced grain size profiles, and greater bioturbation, although the overall Holocene section thickness is moderately expanded (expanded below $\sim 3500$ cal yr BP, and compressed above that age). We estimate a $\sim 25 \%$ increase in overall thickness in this area relative to the Rogue Apron core 01JC based on correlation of key horizons in Fig. 8. (A high resolution version of Fig. 8 is available as Fig. S3 in the Supplement to this article). Figure 7 shows further details of selected beds with enhanced CT and grain-size analysis. Further to the south, beginning at $\sim 41.7^{\circ} \mathrm{N}$ at the site of M9907-34PC, the section decreases in thickness to minimum, then begins to increase southward with an attendant increase in calibrated gamma density and basal grain size in correlative beds. At approximately $41.2^{\circ} \mathrm{N}$, near the site of TN0909-06JC/TC, correlation of key beds indicates a thickening section, which increases further to $180-200 \%$ of the Rogue Apron values at $41.00^{\circ} \mathrm{N}$, the site of TN08909-07PC/TC. The variation in section thickness is corroborated by Chirp reflection profiles, discussed below. Most of this thickness increase can be attributed to nine additional beds that appear in the section younger than $4800 \mathrm{cal}$ yr BP, mostly toward the southern end of the region between Rogue Apron and Trinidad Plunge Pool. Six of these beds are below the likely 1700 AD turbidite, while three are younger, and are discussed below. These beds have sharp bases and fining upward sequences, but are not correlated over large enough distances or linked to onshore paleoseismic sites, thus their origin is presently not testable. We see no coherent increase in bed thickness southward for most beds, despite a clear density and grain size increase (Supplement, Table S4 and Fig. S1). 


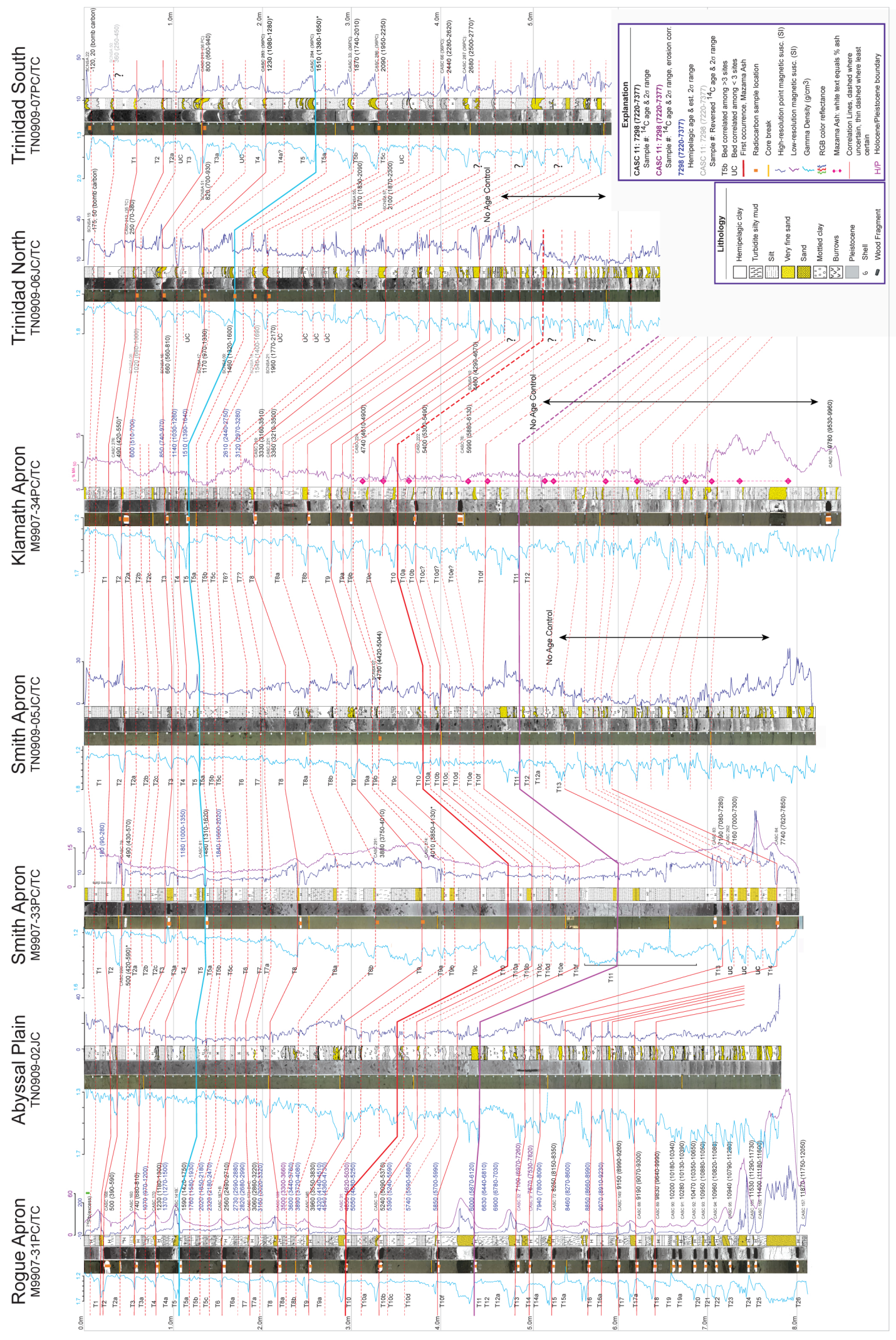

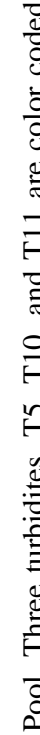

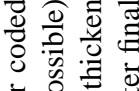

흥

0 范

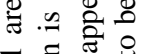

$\exists$.

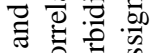

○。

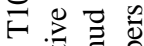

解要

的辟

.

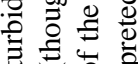

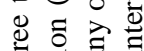

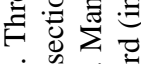

कें

品品

主导志声

च $: \exists]$

青贯

$\exists \boxminus$

$\stackrel{\Xi}{\Xi}$

올 즐

홍

完资

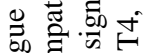

ฯ ठठํ

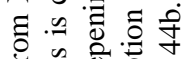

$\exists$ 过

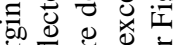

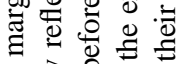

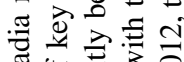

出

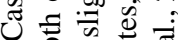

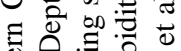

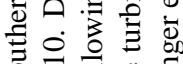

후을 응

㩆部

思.

छิ

总语焉

? 击出

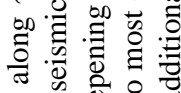

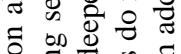

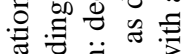

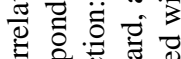

ठै क्षे

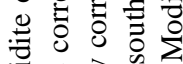

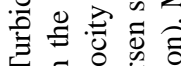

舟

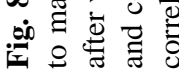


In addition to the increase in overall section thickness, grain size profiles for most beds coarsen southward. For example, in Fig. 8, we interpret regionally correlated beds T1T11 to extend at least southward to Trinidad Pool. Older beds may also be correlative, however interpretation below that depth is hampered by increasing turbidite frequency, sparse hemipelagic intervals for datable material, and other factors as discussed in Goldfinger et al. (2012), thus we focus on the latter half of the Holocene. The CT and density shifts are visible in Fig. 8. Supplement Table S4 and Supplement Fig. S1 show the southward increase in mass, density, and grain size in the data. Not all beds increase in density and grain size southward however. Regionally correlated beds designated T1, T4, T7 and T6 at Rogue Apron diminish in density and grain size southward, bucking the regional trend and making correlation of adjacent beds less robust. The largest regional beds, T11 and T16 also diminish southward. Regional beds T2, T3, T5, T5b, and T5c become more prominent southward, to an extent greater than the regional trend. Many other beds show local variability while generally following this trend. An extreme example is an anomalous event we interpret as correlative to regional event T11, which at Smith Apron (M9907-33PC) apparently expands to $\sim 1.2 \mathrm{~m}$ in thickness, and appears to coarsen upward. Beds T4 and T5 are also anomalously coarse and thick in M990736PC (Trinidad Plunge pool, Goldfinger et al., 2012).

In the well resolved section younger than $\sim 4800$ cal yr BP of particular interest are the proposed along-strike correlation of the 13 Rogue mud turbidites in that time window, T2a, T3a, T4a, T5a, T5b, T5c, T6a, T6b, T7a, T8a, T8b, T9a and T9b. In Fig. 8 we show our preferred interpretation of the lithostratigraphy of all beds between Rogue Apron and Trinidad Pool, an along-strike distance of $150 \mathrm{~km}$, with additional details shown in Fig. 7. Our interpretation suggests that most or all of the thin beds at Rogue are likely present at the Smith (33PC/TC and 05JC/TC) and Klamath sites (34PC/TC) during this period. We also note that T4, T6, T6a, T7 and T7a thin southward beyond the Smith and Klamath area, with T6a not present between Rogue Apron and Trinidad North. We interpret that very weak T6 and T7 turbidites may continue southward to the Trinidad North site, though this interpretation is less robust than for other beds and is mostly based on similarity of the stratigraphic sequences, as these beds are not dated and do not have diagnostic geophysical signatures.

Three additional thin beds appear in the Smith, Klamath and Trinidad North cores, here named T2b, T2c, and T9c because they are likely present over the $\sim 130 \mathrm{~km}$ distance between these sites. At the Trinidad North site (TN090906JC/TC), we interpret the continuation of the same turbidite sequence from Rogue Apron to the Trinidad North site, an along-strike distance of $130 \mathrm{~km}$. At Trinidad North, core 06JC/TC has a somewhat less expanded section than that of the Smith and Klamath cores, but retains robust expression of most of the major and thin beds and a nearly identical sequence for times younger than $\sim 4800$ cal yr BP, with the exceptions mentioned above. Available radiocarbon data from the southern core sequence support our preferred correlation shown in Fig. 8, but with additional radiocarbon data, other interpretations may also satisfy the data.

\subsection{Regional seismic stratigraphy}

Here we examine the seismic stratigraphy of the southern Cascadia margin, focusing particularly on the area from Rogue Apron southward to Trinidad Canyon and Plunge Pool to assess the local and regional continuity of the Holocene and latest Pleistocene abyssal plain turbidite stratigraphy. Regionally, the Chirp reflection profiles occasionally cross previously unmapped low amplitude folds and faults seaward of the frontal thrust, as well as several thin debris slides visible in the section. A primary observation is that despite these complications, the variability of the turbidite sequence is remarkably low along strike in southern Cascadia. Overall, the continuity of reflectors along $\sim 100 \mathrm{~km}$ of the margin shown in Fig. 9, and $\sim 130 \mathrm{~km}$ length in Fig. 10 is apparent at the resolution of detection of these data with respect to the major reflectors in the Holocene section. The overall thickness of the Holocene turbidite section increases northward in the direction of the distal Astoria Fan, thickening $25 \%\left(2 \% \mathrm{~km}^{-1}\right)$ in the section shown in Fig. 9. Southward from Rogue Apron, the section is relatively constant in thickness for a distance of $\sim 150 \mathrm{~km}$ (Fig. 10), first thickening slightly, then thinning, and thickening again near the Trinidad Plunge Pool and Eel Canyon systems, the major sediment distribution systems along the southern Cascadia margin. This observation was initially surprising, as we had expected the turbidite stratigraphy to have a more significant source relationship to the mouths of canyons, thinning rapidly away in all directions. The data show that this is not always the case, and in fact, the Rogue Apron, at the mouth of the very large Rogue Canyon, is located at a regional thin spot in the Holocene trench fill. This effect is pronounced, and is not a bias from the distribution of reflection profiles and cores. These profiles suggest this effect may be due to the presence of pre-Holocene topography developed from Pleistocene sequences that are visible in Fig. 11.

Cores at the Rogue Apron (M9907-30 and 31PC, TT 090901JC/TC, located $5 \mathrm{~km}$ more distally; Fig. 4) show a local seaward thickening, apparently due to bypassing of the more proximal sites. The Chirp dip lines at this location and several to the north however, show clear seaward thinning, starting at about the position of 01JC, and thinning $\sim 10 \%$ in two-way travel time over the next $8.3 \mathrm{~km}$ seaward along our dip line. The seismic profiles show the broader trend over a wider margin parallel swath than can be addressed with the southern Cascadia cores alone.

The Chirp profiles do not image the thinner mud turbidites directly at Rogue Apron, which we now recognize to represent a minimum thickness of the Holocene section. We traced 


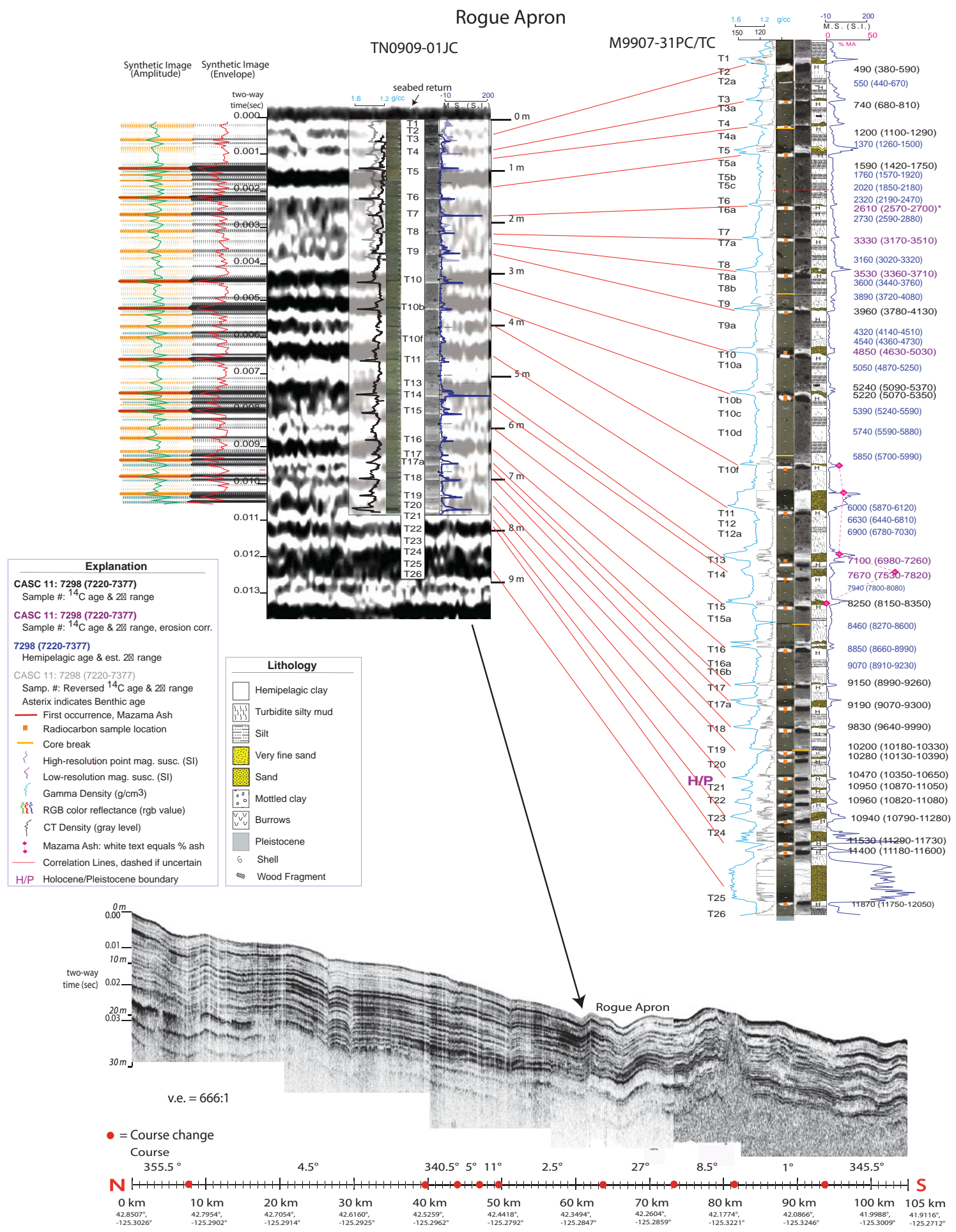

Fig. 9. Compilation of $\sim 100 \mathrm{~km}$ of high-resolution Chirp reflection profiles parallel to the Cascadia margin. Chirp system center frequency was $4 \mathrm{kHz}$, sweeping through $2-6 \mathrm{kHz}$. See Fig. $1 \mathrm{~b}$ for profile location. Correlated horizons correspond to margin-wide larger turbidites with thicker sand bases observed in Rogue Apron cores. This correlation is shown in the inset at center with core TN0909-01JC/TC and representative seismic section. Correlation ties to nearby core M9907-31PC/TC with age control shown at right. Synthetic envelope and amplitude plots from core density data from 31PC/TC shown at upper left. Margin parallel profiles image the entire Holocene section, include the late deglacial, and show the consistency of the turbidite stratigraphy and accommodation space required for sequences of thin mud turbidites along strike. 


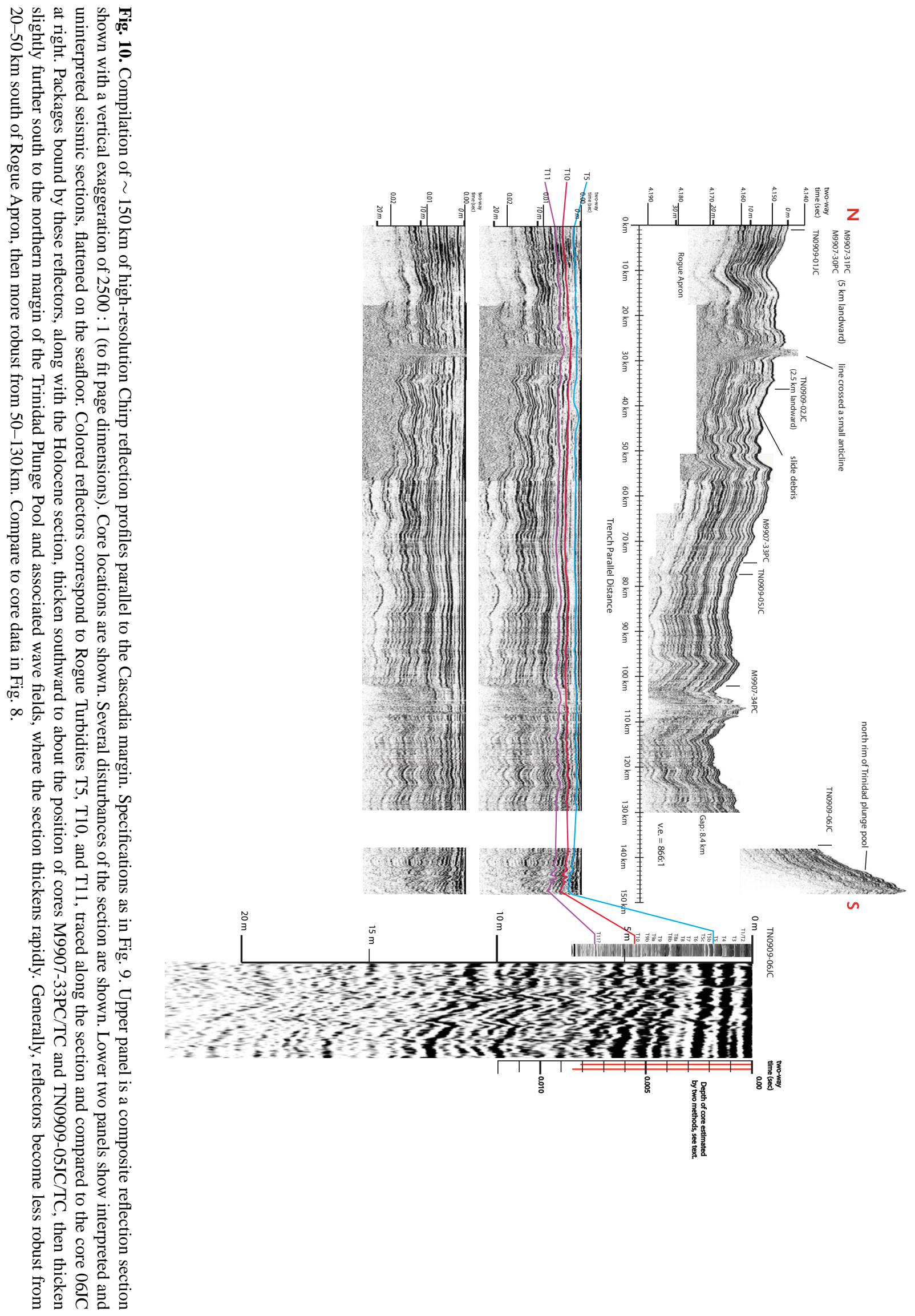


Holocene reflectors northward toward Hydrate Ridge at the base of slope and found that no additional reflectors appear in the section, and no major reflectors terminate $(60 \mathrm{~km}$ of section are shown in Fig. 9). The $2 \% \mathrm{~km}^{-1}$ increase in Holocene section thickness to the north may indicate either increasing sediment supply, increasing bed thickness at the southern margin of the Astoria Fan, or, alternatively, the addition of beds not imaged by the Chirp data.

Our correlation with the core data reveal that the Chirp data are capable of imaging most of the main series turbidites correlated for long distances along strike, with the very thin T12 excepted (Fig. 9). The imaged reflectors correlate well with the thickness of sand at the turbidite bases in the cores, which drives the impedance contrast, not with the overall thickness of the turbidite beds. For example, T5 is the first bright reflector separable from the more difficult to interpret near surface reflectors, and regionally has a high sand content in comparison to T1-4. Below T5, T6-T9 comprise a less robust group in terms of coarse sand, and are imaged as a more transparent package (Figs. 9, 10). The data also image reflectors we correlate with T10, T10b, T10f, T11, T13-14 (merged), T15, T16, T17, T17a, and T18, as well as numerous similar reflectors below the reach of the cores, extending into the deglacial period. A very thick coarse bed at the base of our Rogue cores, T25, is clearly imaged as a strong reflection near a major boundary between Pleistocene and the late deglacial-Holocene section. The clear correlation allows an empirical test of the resolution of the data, which clearly image T17 and T17a, two small turbidites that are separated by $18 \mathrm{~cm}$ in the cores. Allowing for a possible 5$10 \%$ coring compaction, the resolution of the processed data is $18-20 \mathrm{~cm}$, slightly better than the theoretical estimate. The correspondence of these reflectors with the more robust sand bases in the turbidites is quite good, and allows relatively robust tracking of individual turbidites between core sites and along strike for at least $240 \mathrm{~km}$.

To the south of Rogue Apron, we can test our stratigraphic correlations shown in Fig. 10 by observing the depths of major reflectors at the core sites. Figure 10 shows a normal and flattened section of the reflection data from Rogue Apron $130 \mathrm{~km}$ southward to the northern margin of Trinidad Plunge Pool. An easy bed to trace is the first bright reflector below the surface beds. We associate this reflector with T5 (Fig. 9), and track this bed along the entire length of Fig. 10, though as with many of the reflectors, they weaken and are somewhat difficult to trace through the region from $30-50 \mathrm{~km}$ south of Rogue. This key reflector varies somewhat in depth along strike, first deepening and then shallowing slightly $30-50 \mathrm{~km}$ south of Rogue, but remaining at a relatively constant depth of $\sim 1 \mathrm{~m}$ below the seafloor. Cores near Trinidad Plunge Pool $130 \mathrm{~km}$ to the south also show this correlated unit at $\sim 1.6 \mathrm{~m}$ depth (Fig. 8). Figures 8 and 10 show this bed, as well as beds T10 and T11, in the core data and seismic section with the same color coding. These key beds show that the overall section thickness trends are consistent between the core and seismic stratigraphy.

We can make several observations from the reflection data that bear on the lateral continuity of the thin beds. First, with continuity of the thicker regional turbidites, the context is present for continuity of the thinner beds; something we suggest is a primary requirement for the stratigraphic section. Second, the continuity of the stratigraphic section along strike includes more than simple continuity of the individual reflectors. We observe that interval thicknesses between the primary reflectors remain quite consistent along strike as well, and reflect a gradual southward thickening of the overall section. For example, the unusually thick interval between T5 and T6 of $\sim 50 \mathrm{~cm}$ is clearly imaged in the Chirp data, and maintained among all cores at Rogue Apron , and cores south of Rogue apron (Figure 7) as well as at Hydrate Ridge (Fig. 3). This distinctive interval is one of the elements we have used to correlate major turbidites along strike with both core and Chirp data. This interval is represented by $\sim 1000 \mathrm{yr}$ between the average age of T5 and T6. We have interpreted that the vertical interval is mostly filled with three mud turbidites, T5a, T5b, and T5c at Rogue Apron and Hydrate Ridge, and would otherwise require an exceptionally high hemipelagic sedimentation rate of $50 \mathrm{~cm} / 1000 \mathrm{yr}$. to account for the accumulation of $50 \mathrm{~cm}$ of hemipelagic material. The regional continuity of the $50 \mathrm{~cm}$ interval between $\mathrm{T} 5$ and T6 therefore implies that although we cannot image the three mud turbidites with Chirp reflection methods directly, they are likely to present in the imaged section (Figs. 9, 10) and account for the consistent thickness and the $\sim 1000 \mathrm{yr}$ of time that exists between T5 and T6. The $\sim 100 \mathrm{~cm}$ thickness of the interval between $\mathrm{T} 11$ and T10, representing a time interval of $\sim 1200 \mathrm{yr}$ also maintains its interval thickness regionally. This interval includes with two thicker beds, T10b and T10f, that are imaged in the Chirp data, and three mud turbidites, T10a, T10c, and T10d that are not. We infer that the continuity of accommodation space implies continuity of the thinner beds as well (Figs. 9-10).

\section{Discussion}

\subsection{Triggering mechanisms}

Stratigraphic correlation of individual beds among separated sites offers a test of event synchroneity, particularly in cases where sites are isolated from each other and from shallow water and terrestrial sediment sources. When applicable, correlation of detailed lithostratigraphy (i.e., "fingerprinting" of turbidites through CT data and grain size proxies), combined with age compatibility from both radiocarbon and time calculated from hemipelagic sedimentation (at the resolution of radiocarbon), can be the basis for assessing synchronous deposition at separated sites. This method relies mainly on a large number of sites, as individual bed characteristics may 
or may not be diagnostic (Goldfinger et al., 2007, 2008, 2011, 2012; Patton et al., 2009).

That such grain-size "fingerprint" comparisons can sometimes be made suggests that the processes that produced them likely have some commonality, as producing very similar grain size patterns in multipulse turbidites by coincidence is unlikely. If common mode correlative patterns exist, to be diagnostic they must be reproduced in multiple canyon/channel systems, and ideally in isolated settings with no sources of terrigenous input or shallow water influence by storm waves or tsunami. Detailed stratigraphic fingerprinting is a relative dating test, where synchronous deposition or lack thereof may be tested, and is independent of absolute dating techniques and the inherent uncertainties involved in their use.

The southern Cascadia thin beds are more equivocal in their interpretation due to bioturbation, and likely due to reduced efficacy of the geophysical grain size proxies in the finer fractions due in part to the biogenic component. Figure 7 shows that this effect may be reduced by plotting the mode of log-transformed grain size data. Bioturbation plays a much greater role in overprinting sediment stratigraphy for the thin beds. The thicker turbidites are much less disturbed by bioturbation, probably because the benthic infauna was smothered by the rapid burial event, where the smaller turbidites likely did not bury and kill the local infauna. For the thin beds, the effect may have been just the opposite, bringing enough nutrients to abyssal settings to actually cause an infaunal bloom (Thomson et al., 1988; Smith et al., 1993). In addition, the thinner beds are simply not of sufficient scale in some cases, particularly at Rogue Apron to avoid significant overprinting and obscuration by bioturbation at even average background levels. This is the primary reason that multiple cores at a given site are desirable, because these artifacts in any single core can by identified as "noise" with multiple cores, but can be misleading when considered in only one core. Another factor is that geophysical grain size proxies are nearer to their lower limit of resolution.

Brunner and Normark (1985) and Brunner and Ledbetter (1985, 1987, 1989) closely examined biostratigraphy of mud turbidites in an effort to define both mechanical and faunal discriminators to identify mud turbidites. Although they were largely successful, they also caution that such discriminators are highly subject to local physiography and the local hydrodynamics in terms of the evidence left behind in each deposit. These types of faunal counting and fabric analysis techniques are exceptionally labor intensive, and ultimately may or may not be definitive, therefore multiple proxies and correlation techniques are likely more effective in practice.

The continuity of seismic reflectors in the Holocene section along $240 \mathrm{~km}$ of the abyssal plain centered on Rogue Apron was surprising to us. Both the lack of thickening of the section at the Rogue Canyon mouth, and the continuity of the reflectors along strike suggest that the delivery of turbidites to the southern Cascadia abyssal plain may be accomplished in part by sheet flows from the lower continental slope. The lack of Mazama ash in any cores south of Rogue Apron attests to the lack of significant transport along the base of the continental slope.

The case for intrasite and intersite consistency of the thin beds is based more on the stratigraphic consistency between sites than on individual bed structure. Consistency at our key Rogue site was improved with addition of the 2009 core TN0909-01JC/TC, which showed that Rogue intersite linkages from earlier work were replicated precisely in this core, which is several $\mathrm{km}$ more distal than the original 1999 Rogue cores. Overall, the consistency of the records among the large number of cores spanning $380 \mathrm{~km}$ from Hydrate Ridge to Trinidad plunge pool is consistent with regional synchronous triggering.

The 21 correlated thin turbidites and the 2 thicker ones represent an average recurrence interval of $\sim 430 \mathrm{yr}$ for the thin beds. The long interval suggests that alternative triggers, such as major storm events, are unlikely for many of the same reasons that apply to the larger turbidites. A detailed discussion of alternate mechanisms is presented in Goldfinger et al. (2012) and is not repeated here. We see no evidence of hyperpycnal flows in the beds discussed in this study, though we limit this discussion to the latter half of the Holocene south of Rogue Apron. The evidence for bed correlation between Hydrate Ridge and Rogue Apron, and southward to Trinidad Plunge Pool is best explained by plate boundary earthquakes of limited rupture length. Crustal and slab earthquakes could also contribute to the record, though the strike lengths of such events do not seem consistent with the turbidite strike lengths. In addition to the intersite correlation, the preferred interpretation of the presence of thinner turbidites at Hydrate Ridge places an additional constraint on possible origins in that shallow-water and terrestrial origins, such as storm or tsunami triggering, are excluded at the isolated Hydrate Ridge site.

In summary, while fewer tests of origin are available for these beds than for the margin-wide turbidites, the new core data are consistent with the seismic interpretation of the correlative turbidites in this expanded study. The analysis presented here further supports the existence of at least three southern Cascadia seismic segments in addition to full margin ruptures (regional T1-T18; Goldfinger et al., 2012, their Fig. 55). To this interpretation, we have added one possible turbidite limited to the northern margin, T15AN and one additional thin bed, T16b. Close examination of northern Cascadia abyssal plain cores reveals no other coherent turbidites that can be linked with enough data to interpret additional northern Cascadia earthquake ruptures. Several uncorrelated turbidites in proximal Washington canyon locations that were noted by Adams (1990) in the original OSU and University of Washington 1960s cores could represent such northern events. Similarly, we note that a small number of uncorrelated turbidites are also present in some of our proximal cores such as the Hydrate Ridge cores M9907-56PC and 
02PC. These uncorrelated beds are not common, and limited to very proximal sites. They may be the result of random self-failures, or perhaps small local earthquakes.

\subsection{Regional comparisons of the turbidite stratigraphy}

The regional core set allows comparisons between primary sites along the Cascadia margin that may bear on the mud turbidite issue. A primary observation is that the thickness of the Holocene stratigraphic section varies considerably from site to site. At JDF, the Holocene section with T18 at its base is contained in $300 \mathrm{~cm}$ vertically. At Rogue Apron, the same section requires $\sim 680 \mathrm{~cm}$, thicker by more than a factor of two. These two sites are roughly equivalent in terms of the hydrodynamics of the turbidity currents that delivered these turbidites in that they both lie at the base of the continental slope, and yet the section thicknesses are notably different. Other differences are that the sediment supply delivery to the canyon heads is likely greater at JDF, as this system is supplied by the Columbia River, where the much smaller Rogue system supplies Rogue Canyon. The JDF canyon must pass through a longer more tortuous path through the broad Washington accretionary wedge however, where the multiple arms of the Rogue Canyon are shorter, straighter, and steeper, suggesting less sediment retention in that system.

Which of these factors account for the great difference in section thickness? We can examine the total contribution of the turbidites and the hemipelagic sediment to address this question. We compare our four key sites and JDF, Cascadia, Hydrate Ridge and Rogue Apron. Of the four primary sites, each of which has multiple cores and extensive age control (Goldfinger et al., 2012), the total mass of all Holocene turbidites correlated along strike is remarkably consistent. Table 2 shows the mass of each regional turbidite in the Juan de Fuca, Cascadia, Hydrate Ridge and Rogue Apron cores, and the sum of the masses for the cores. The total mass (unscaled value; see Goldfinger et al., 2012, for method details) varies from a low of 8, 930 at Hydrate Ridge, to a high of 11170 at Rogue Apron, a narrow range of $\sim 20 \%$ variability among the four sites. Surprisingly, despite the numerous differences in sediment supply, the physiography of the canyon/channel systems, and the path length for the turbidity currents, the turbidites themselves do not vary that much between these sites. This may well be a coincidence, however comparisons between JDF and Rogue may be instructive.

As described more fully in Goldfinger et al. (2012), the down-core series of mass values per turbidite can also be compared between the same four key sites to examine the turbidite sequence in more detail (Table 2). Table 3 shows the results of this comparison using a Pearson correlation matrix. The values range from a low value of 0.60 between Hydrate Ridge and Rogue Apron, to $0.68-0.79$ for the comparisons between the other sites. (The result is slightly modified from a matrix given in Goldfinger et al., 2012, with an additional value for T16 from the new 2009 core TN0909-01JC). The correlation between sites is moderately strong, considering the lack of physical connection between the sites (except JDF and Cascadia) the distances between sites, which are 250$620 \mathrm{~km}$, and the lack of any expectation that these parameters should correlate at all. Interestingly, the lowest value corresponds to the two sites spatially closest together, and most closely correlated stratigraphically. The correlation between the mass series per site, and the narrow range of variability between the total mass of all turbidites per site indicates a broad consistency in the sediment delivered by the regional series of turbidites along strike during the Holocene. Unlike the correspondence of total mass of Holocene turbidites at the four sites, the inter-site correlation of the vertical bed-bybed series of mass values (and grain size profiles, Goldfinger et al., 2008, 2012) is unlikely to be the result of chance. This linkage demonstrates that the driver of these similarities is most likely the earthquakes themselves, rather than other external factors. This property and its implications are discussed in Goldfinger et al. (2012). Together, the close correspondence of total mass and bed-by-bed correspondence demonstrates that the factor of two differences in thickness between JDF and Rogue Apron, and differences at all four sites cannot be attributed to differences in the regionally correlated turbidites. We note that, to date, we do not observe similar regional correlation of turbidite mass sequencing in cores from Sumatra or northern California.

If the regional turbidite stratigraphy cannot account for the total thickness difference, the hemipelagic sedimentation rate could be responsible. Regionally we can compare the hemipelagic sedimentation rate at various sites and the regional total thickness of hemipelagic sediment at those sites to test this possibility. At Rogue apron, we interpret an average hemipelagic sedimentation rate of $15 \mathrm{~cm} / 1000 \mathrm{yr}$ (uncorrected for compaction; Goldfinger et al., 2012). Similar rates are observed at Juan de Fuca $(10 \mathrm{~cm} / 1000 \mathrm{yr})$, Hydrate Ridge $(11 \mathrm{~cm} / 100 \mathrm{yr})$, Astoria Channel $(14 \mathrm{~cm} / 1000 \mathrm{yr})$, and the Cascadia Channel $(13 \mathrm{~cm} / 1000 \mathrm{yr})$. These rates are similar outside of the major channel systems as well. Interchannel cores in the Cascadia Basin with limited turbidite influence contain a typical $90-116 \mathrm{~cm}$ of Holocene hemipelagic material (Goldfinger et al., 2012, their Fig. 48), an average sedimentation rate of 9-12 cm/1000 yr, comparable to our turbidite sites calculated by removing the turbidite thicknesses. The hemipelagic rates are quite consistent throughout the Cascadia Basin within the range of distance from the margin included in this study, all of which are east of the Cascadia Channel (Fig. 1).

At the Rogue Apron site, the sedimentation rate of $\sim 15 \mathrm{~cm} / 1000 \mathrm{yr}$ is calculated after removal of all turbidites, including the interpreted mud turbidites. Only then is it comparable to other sites. If the mud turbidites were not removed, the section would require a hemipelagic sedimentation rate of $\sim 50 \mathrm{~cm} / 1000 \mathrm{yr}$, a five-fold increase in the hemipelagic rate over other sites, a rate for which we can find no justification or explanation. We infer that the inclusion of the 
Table 2. Turbidite mass totals per site.

\begin{tabular}{|c|c|c|c|c|c|c|c|c|c|}
\hline $\begin{array}{r}\text { Turbidite } \\
\text { number }\end{array}$ & $\begin{array}{r}\text { Mean } \\
\text { age }\end{array}$ & $\begin{array}{r}\text { OxCal } 2 \\
\text { range }\end{array}$ & $\begin{array}{l}\text { Standard dev. } \\
\text { of mean ages }\end{array}$ & $\begin{array}{r}\text { Margin average } \\
\text { following interevent } \\
\text { time, years }\end{array}$ & $\begin{array}{r}\text { Margin average } \\
\text { prior interevent } \\
\text { time, years }\end{array}$ & $\begin{array}{r}12 \mathrm{PC} \\
\text { scaled } \\
\text { mass }\end{array}$ & $\begin{array}{r}23 \mathrm{PC} \\
\text { scaled } \\
\text { mass }\end{array}$ & $\begin{array}{r}31 \mathrm{PC} \\
\text { scaled } \\
\text { mass }\end{array}$ & $\begin{array}{r}56 \mathrm{PC} \\
\text { scaled } \\
\text { mass }\end{array}$ \\
\hline 1 & 268 & $199-338$ & & & 226 & 449.8 & 398.4 & 347.0 & 314.8 \\
\hline 2 & 494 & $448-548$ & 83 & 226 & 307 & 295.6 & 154.2 & 514.0 & 141.4 \\
\hline 3 & 801 & $760-840$ & 55 & 307 & 426 & 398.4 & 347.0 & 642.5 & 816.0 \\
\hline 4 & 1227 & $1178-1277$ & 42 & 426 & 356 & 282.7 & 347.0 & 347.0 & 861.0 \\
\hline 5 & 1583 & $1513-1654$ & 32 & 356 & 960 & 295.6 & 604.0 & 475.5 & 462.6 \\
\hline 6 & 2543 & $2486-2602$ & 23 & 960 & 471 & 501.2 & 578.3 & 372.7 & 719.6 \\
\hline 7 & 3014 & $2922-3105$ & 61 & 471 & 447 & 873.8 & 809.6 & 546.1 & 539.7 \\
\hline 8 & 3461 & $3378-3542$ & 68 & 447 & 650 & 1002.3 & 436.9 & 475.5 & 771.0 \\
\hline 9 & 4111 & 4037-4186 & 52 & 650 & 650 & 745.3 & 359.8 & 436.9 & 244.2 \\
\hline 10 & 4761 & $4666-4865$ & 52 & 650 & 1132 & 385.5 & 192.8 & 552.6 & 205.6 \\
\hline 11 & 5893 & $5798-5990$ & 111 & 1132 & 552 & 1182.2 & 1606.3 & 1503.5 & 1002.3 \\
\hline 12 & 6445 & $6349-6543$ & 102 & 552 & 724 & 102.8 & 115.7 & 51.4 & 192.8 \\
\hline 13 & 7169 & $7121-7218$ & 44 & 724 & 439 & 668.2 & 282.7 & 886.7 & 488.3 \\
\hline 14 & 7608 & $7547-7669$ & 39 & 439 & 573 & 269.9 & 269.9 & 257.0 & 77.1 \\
\hline 15 & 8181 & $8071-8293$ & 95 & 573 & 757 & 257.0 & 154.2 & 591.1 & 192.8 \\
\hline 16 & 8938 & 8781-9106 & 62 & 757 & 154 & 1156.5 & 2852.7 & 1498.0 & 1040.9 \\
\hline 17 & 9092 & $8966-9212$ & 38 & 154 & 100 & 231.3 & 501.2 & 334.1 & 282.7 \\
\hline $17 \mathrm{a}$ & 9192 & $9000-9357$ & 39 & 100 & 565 & 154.2 & 141.4 & 681.1 & 154.2 \\
\hline \multirow[t]{2}{*}{18} & 9757 & $9629-9911$ & 94 & 565 & 388 & 244.2 & 501.2 & 655.4 & 424.1 \\
\hline & & & & & mass totals per site & 9496.2 & 10652.7 & 11167.6 & 8930.8 \\
\hline
\end{tabular}

Table 3. Pearson correlation, mass per event by site.

\begin{tabular}{rrrrr}
\hline & $12 \mathrm{PC}$ & $23 \mathrm{PC}$ & $31 \mathrm{PC}$ & $56 \mathrm{PC}$ \\
\hline $12 \mathrm{PC}$ & 1 & & & \\
$23 \mathrm{PC}$ & 0.724113066 & 1 & & \\
$31 \mathrm{PC}$ & 0.698876666 & 0.790911571 & 1 & \\
$56 \mathrm{PC}$ & 0.681114201 & 0.683977407 & 0.603208391 & 1 \\
\hline
\end{tabular}

interpreted mud turbidites is required to account for both the rates and total thickness of hemipelagic sediment deposited between turbidites. We infer that the difference between JDF and Rogue is therefore not due to regional hemipelagic sedimentation rates, and is not due to differences in the regional turbidites themselves, which are not large enough. The difference is the presence of the 23 southern turbidites, which are not present at JDF (with one possible exception discussed below). In Fig. 11, we summarize the differences between the JDF and Rogue Apron sites graphically. Cores for both sites are shown schematically but at true scale side by side. While the similarities in mass and total thickness of sandy turbidites might be coincidence, it allows a direct comparison of other differences. To the JDF core, we add the thickness of mud turbidites, the differential in hemipelagic sedimentation rate, the difference in regional turbidite thicknesses between sites, and the difference in total basal erosion as compiled in Goldfinger et al. (2012). When compensated for these known differences, the cores are essentially the same length, differing by only $22 \mathrm{~cm}$. Figure 11 graphically illustrates the contribution of the 21 interpreted mud turbidites, and the two sand turbidites limited to the southern margin which comprise most of the difference.

Similarly, the Astoria site has a complete Holocene section of $\sim 330 \mathrm{~cm}$ in length. This section is interpreted to include three to four of the thinner turbidites, which are correlated in Goldfinger et al. (2012) to T5b, T8a or b, T9a, and T10b. These correlations could be incorrect, and the Astoria beds may be slightly different than those at other sites to the south, or alternatively, they could be local uncorrelated beds. In any of these alternative interpretations, the section thickness at the Astoria site, also a base of slope site is comparable to JDF, with the addition of the four thin beds. Again, we note that the difference in total section thickness between Astoria and Rogue Apron is approximately equivalent to the total thickness or mass of the missing mud turbidites that are present at Rogue. Lastly, we compare Hydrate Ridge to Rogue Apron. The HR site was interpreted by Goldfinger et al. (2012) to include about half of the thinner turbidites present at the Rogue site. Radiocarbon ages, calculated ages, and stratigraphic correlation suggest that the HR site likely contains beds T3a, T4a, T5a, T5b, T5c, T9a, T10a, T10b, T10c, T10f, T12a, T16a, and the newly interpreted T16b. Alternatively, these beds could represent random events located in similar stratigraphic positions at the two sites. The total Holocene section is $770 \mathrm{~cm}$ thick at the Hydrate Ridge site, $13 \%$ thicker than at Rogue Apron, despite the missing mud turbidites. The Hydrate Ridge site is perhaps not as comparable to the other base of slope sites 


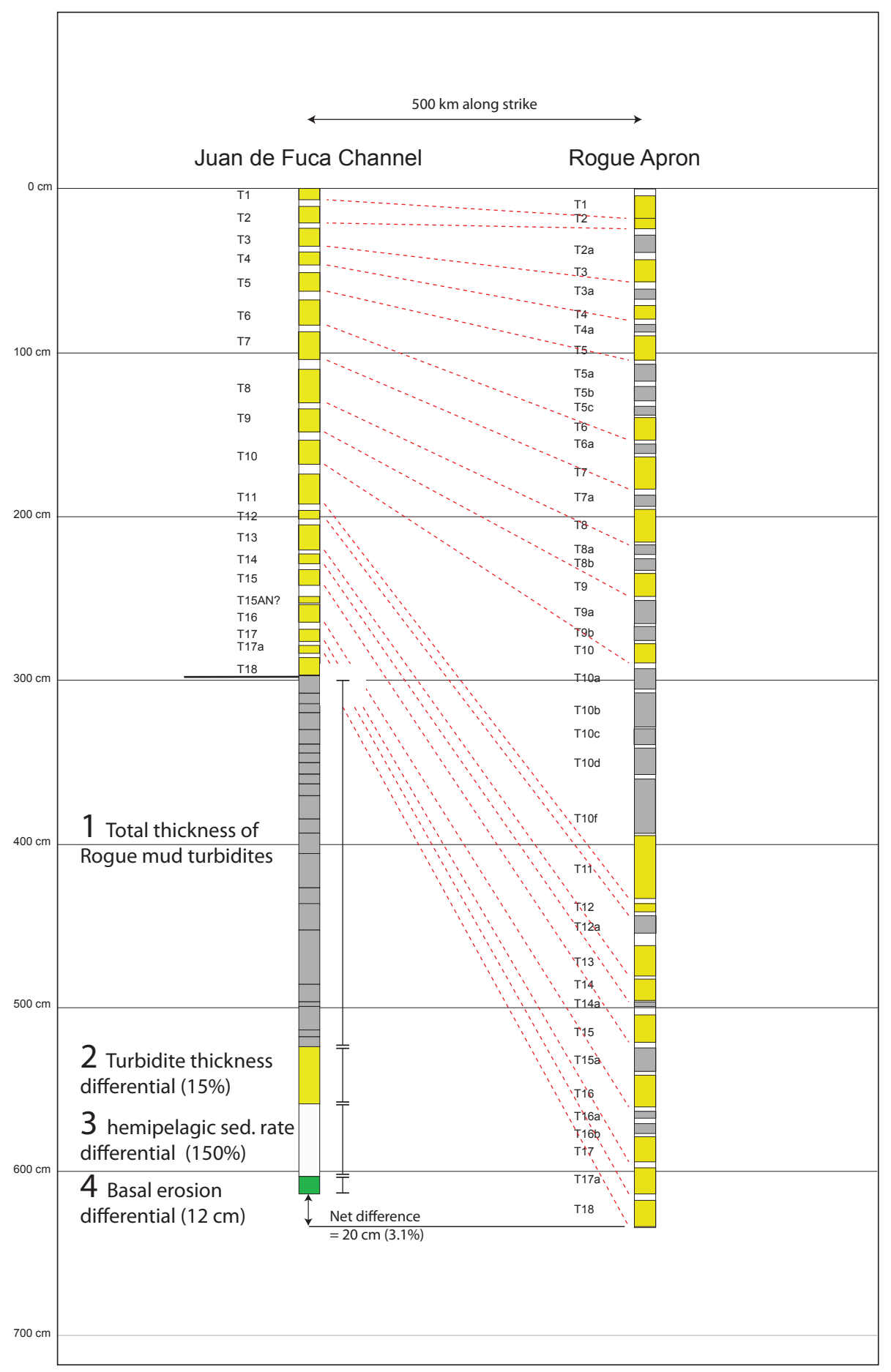

Fig. 11. Schematic comparison of stratigraphic sequences at the Juan de Fuca Channel and Rogue Apron at true scale. Major sandy turbidites for both cores are shown in yellow, mud turbidites shown in grey. Below the JDF core diagram, we add four units that represent the difference between the two sites. (1) The total thickness of mud turbidites from Rogue Apron; (2) the increased overall thickness of Rogue turbidites, $15 \%$ greater than JDF, is added to both mud and sand turbidites; and (3) the $150 \%$ difference in hemipelagic sedimentation rate (Goldfinger et al., 2012); and (4) the difference in basal erosion at the turbidite bases, compiled from Goldfinger et al. (2012). The net difference in Holocene section thickness is $\sim 22 \mathrm{~cm}$ or $3.1 \%$, with the greatest component of the section difference attributable to the presence of 23 southern Cascadia turbidites present at Rogue Apron. 
in that it is a lower slope basin not fed by a canyon system. We infer that this section thickness difference is most likely attributable to the very different site physiography and the proximal location of the Hydrate Ridge cores at the base of the cliff bounding the Hydrate Ridge west basin. The multiple cores at that site demonstrate a rapid thinning of the sedimentary section away from this bounding cliff. Core $01 \mathrm{KC}$, positioned only $2.31 \mathrm{~km}$ more distally from our primary core $56 \mathrm{PC}$, is $248 \mathrm{~cm}$ in length, with a basal age of 24600 (24 320-25 020) cal yr BP. The distal thinning of the Holocene section at other sites is much more gradual than the dramatic thinning observed at Hydrate Ridge, making it difficult to use the total thickness comparisons as we have done for other sites.

In the Supplement, we briefly discuss preliminary observations of cores from the Washington cores from the Washington continental slope and assess the probability of additional northern segmented ruptures.

\subsection{Comparison to onshore paleoseismic sites}

\subsubsection{Bradley Lake, a coastal barrage lake}

Bradley Lake is a coastal lake in southern Oregon that contains a tsunami record of marine sands that inundated the lake. Kelsey et al. (2005) established the requirements for such inundation in detail, and they concluded that the tsunami record there was attributable to a local, rather than distant, tsunami. Goldfinger et al. (2012) discuss a refinement of the radiocarbon ages from Bradley Lake that brings the Bradley Lake event record into better temporal alignment with the offshore turbidite stratigraphy.

The Bradley Lake record is based on tsunami deposited sands for 12 "disturbance events", and on lake-sediment disturbances (local turbidites?) for four others (Kelsey et al., 2005). The Bradley Lake record exhibits a greater number of disturbance events per unit time than other Cascadia onshore records, including 12 sand beds that require a tsunami height of $>5.5 \mathrm{~m}$ to reach the lake (Kelsey et al., 2005). The Bradley Lake tsunami stratigraphy includes maximum (960 yr) and minimum (22 yr) inter-event times (Kelsey et al., 2005), comparable to the offshore minimum and maximum intervals of 1190 and $40 \mathrm{yr}$, respectively.

Bradley Lake may be one of the few onshore coastal sites that has evidence of the smaller class of earthquake generated turbidites inferred at Rogue Apron, Hydrate Ridge, and other southern Cascadia offshore sites. The mean Bradley Lake recurrence interval is $390 \mathrm{yr}(0-4600 \mathrm{cal}$ yr BP; Kelsey et al., 2005); considerably shorter than other onshore paleoseismic localities and somewhat higher than the offshore average of $220 \mathrm{yr}$ for 20 turbidites during the same $\sim 4600 \mathrm{yr}$ period that Bradley Lake was a good paleoseismic recorder (corresponding to offshore turbidites T1-T9a). Bradley Lake does not have an equivalent of the smaller regional $\mathrm{T} 2$ bed, and also has no record corresponding to a number of the thin beds in Rogue Apron cores. The temporal record at Bradley Lake exhibits clusters of events and large time gaps similar to those evident in the offshore record of major turbidites forming strong ties between the two. For the time between T3 and T5 ( 800-1550 cal yr BP), the offshore record contains five turbidites, and Bradley Lake includes the same number of tsunami sands. For this period, both records have a recurrence interval of $\sim 190 \mathrm{yr}$. Between the time of offshore T5 and T6 $(\sim 1550-2550$ cal yr BP $)$, a $1000 \mathrm{yr}$ gap in the major turbidite record, the offshore record includes three thin mud turbidites, T5a, T5b, and T5c, (which become sandy turbidites further south). Bradley Lake recorded no disturbance events during this $\sim 1000 \mathrm{yr}$ gap. The gap itself is a key link between Bradley Lake (and other onshore sites) and the Rogue Apron and Hydrate Ridge sites, and all offshore sites record this $1000 \mathrm{yr}$ gap in the regional turbidite record. (A possible equivalent of T5b is recorded at the Coquille River at $\sim 2100$ cal yr BP, close to the offshore average age of $2040 \pm 150 \mathrm{cal} \mathrm{yr} \mathrm{BP})$. For the period between T6 and T10 ( 2550-4900 cal yr BP), the offshore record includes 11 turbidites, with an average recurrence interval of $235 \mathrm{yr}$. Bradley Lake includes eight disturbance events during that period, with a recurrence interval of $335 \mathrm{yr}$. Prior to that time, Bradley Lake is not considered to have been a reliable paleoseismic recorder (Kelsey et al., 2005).

Based on the temporal record alone, the offshore record includes 15 major turbidites from 250-7200 cal yr BP (including T10b and T10f), and 16 thinner turbidite beds. The Bradley Lake record includes 17 disturbance events during the same period. Bradley Lake includes potential temporal equivalents of 8 of 9 major turbidites (T1, T3, T4, T5, $\mathrm{T} 6, \mathrm{~T} 7, \mathrm{~T} 8$, and $\mathrm{T} 9$ ) during the favorable period of recording, 0-4600 cal yr BP, Bradley Lake also has potential temporal correlatives of thin turbidites T3a, T4a, T7a, T8a, T8b, and T9a, each of which can be categorized as a smaller tsunami based on areal extent and sediment characteristics in the lake (Kelsey et al., 2005; and compared in detail to the offshore turbidites in Goldfinger et al., 2012, their Appendix 11). These six turbidites, with potential direct correlatives in Bradley Lake, are therefore more robustly interpreted as derived from plate boundary earthquakes.

The evidence for tsunami entering Bradley Lake at times that correspond to some of the offshore turbidites, but do not correspond to regional margin-wide earthquakes provides a third independent line of evidence for additional smaller earthquakes in southern Cascadia. Cascadia earthquakes recorded in Bradley Lake must meet the requirement to generate a tsunami height of $\sim>5.5 \mathrm{~m}$ to overtop the barriers to Bradley Lake (Kelsey et al., 2005), which likely excludes slab and upper plate earthquakes, and would likely exclude the local, smaller tsunami, or perhaps those that occurred at low tide. We do not observe a correlation between turbidite mass per event or strike length between the Rogue thinner beds and the presence of a temporally correlative disturbance event in Bradley Lake. 


\subsubsection{Coquille River and Sixes River}

The Sixes estuary and Coquille River onshore paleoseismic records represent the best onshore marsh subsidence-tsunami sites in southern Cascadia. Multiple soils buried by estuary mud show evidence of coseismic subsidence, incursion of tsunami sands with marine diatoms over the wetland soil surface, and some associated liquefaction features (Kelsey et al., 1998, 2000; Witter et al., 2003; Kelsey et al., 2002; Witter and Kelsey, 2004).

The Coquille River site, near Bandon, Oregon, has evidence of fifteen earthquakes, thirteen of which have been dated in a span of $\sim 6500 \mathrm{yr}$ (Witter and Kelsey, 2004). The Coquille site, like Bradley Lake, compares well with the offshore series of larger turbidite beds. In the time range from 250-6600 cal yr BP, all turbidites except T3, T6, and T11 appear to have onshore equivalents. Of the thinner offshore beds, the Coquille River site has temporal equivalents of T5b, T8b, T9a and T10b, having recorded a number of earthquakes that are apparently not margin wide, as did Bradley Lake.

The Sixes River site, Oregon, has evidence of twelve earthquakes, eleven of which have been dated (Witter et al., 2004 ) in $\sim 5900 \mathrm{yr}$, with a recurrence interval of $\sim 515 \mathrm{yr}$, considerably higher than Bradley Lake and the offshore record. The Sixes River paleoseismic record has a long gap with evidence of only one undated earthquake between the $1700 \mathrm{AD}$ earthquake and the next younger dated earthquake at $\sim 2000$ cal yr BP. By comparison, the offshore record includes eight turbidites during that period: T2-T5a. Earlier than $\sim 2000$ cal yr BP, the Coquille River record tracks the offshore paleoseismic record well, with possible temporal correlatives for T5b, T6, T7, T8, T8a or T8b, T9, T10, T10b, and T11 (Goldfinger et al., 2012), which if correct would leave, T10c, T6a, T7a, T8a, T9a, and T10a, T10c, T10d, $\mathrm{T} 10 \mathrm{e}$, and T10f unrecorded onshore.

The Coquille and Sixes River sites are evidently less sensitive recorders of earthquakes than Bradley Lake. They both record some, but not all of the events that are limited to southern Cascadia. The smaller earthquakes they both record may be equivalent to offshore beds T5b, T8a or T8b and T10b. With the exception of T10b, all the missing beds are of the thinner class of turbidites offshore. The potential correlatives are regionally some of the largest of that class, as can be seen in Fig. 8, consistent with these earthquakes having exceeded the recording threshold at the Coquille and Sixes rivers.

Goldfinger et al. (2012) also compared size characteristics of the earthquake evidence at these two sites to the offshore record (their Appendix 11). Like Bradley Lake, the Coquille and Sixes sites track the size characteristics moderately well, and suggest that a recording threshold controls the appearance of smaller earthquakes in the onshore record. Compared to the turbidite record, large events are likely to appear onshore, potential equivalents of small turbidites are commonly absent, and moderate turbidites may be included in the onshore record, but with some gaps. Significant mismatches in relative size and energy proxies were uncommon.

\subsubsection{Humboldt Bay Area}

Valentine et al. (2012) present a new analysis of data collected in the southern Cascadia region in the vicinity of Humboldt Bay and the Eel River delta. Data were collected in a series of studies over several decades, and include bulk peat ages collected at several sites. The large errors associated with these ages are not ideal in modern studies, but nevertheless are still quite useful for a general assessment of coastal subsidence events, particularly when observed at several sites. Coastal subsidence events in the southernmost part of Cascadia are observed at a total of seven sites at four areas including the Mad River slough, two areas of Humboldt Bay, and the Eel River delta. Valentine et al. (2012) assess a total of six coastal subsidence events in terms of the range of abrupt relative sea-level (RSL) rise and the similarity of radiocarbon ages for the events among the sites studied and regional paleoseismic data. Of these rapid submergence events, the authors consider events 1,4 , and 6 to be regional CSZ (Cascadia Subduction Zone) earthquakes, and events 2, 4, and 5 to be potential southern CSZ or even more localized earthquakes. We agree that events 1 and 4 are most likely regional earthquakes based on the onshore evidence of significant subsidence of $0-75 \mathrm{~cm}$ based on marsh vertical zonation and close correspondence in age with other land and offshore sites. Event 2 was considered equivocal, with a reduced observed subsidence of $0-50 \mathrm{~cm}$, and the observation of this event at a subset of the core sites. This less robust event could therefore be either a local or perhaps a smaller regional event. Because a subsidence event with a compatible age was observed at four of seven sites spanning several local structures, we suggest that it might be a regional earthquake. The preferred age range for this event of 500-600 cal yr BP is compatible with the mean turbidite age for offshore event T2 $(480 \pm 100)$ considering the peat age is a minimum limiting age for that event. In the offshore record, T2 is generally a thin event as correlated in Goldfinger et al. (2012), and it is not apparent at most Cascadia onshore sites. The new cores in this study reveal that $\mathrm{T} 2$ increases in thickness southward, and becomes more prominent relative to other beds, suggestive of T2 having a more prominent position in the turbidite stratigraphy, and potentially representing a larger earthquake in southern Cascadia, perhaps reaching a recording threshold and subsequent preservation onshore in southern Cascadia. The next event in chronological sequence is found at the Eel Delta site, dated at $660-920$ cal yr BP. This event is similar to the age of offshore event T3 $(800 \pm 120 \mathrm{cal} \mathrm{yr} \mathrm{BP})$, though with the low precision of peat ages, its age is less certain. Valentine et al. (2012) lump this age in with the much older ages for event E3, which seems unlikely to us. Peat beds E3 and E4 apparently occurred closely in time, with 0-200 yr separating them. E4 is considered a regional event based on 
greater subsidence ( $>50 \mathrm{~cm}$ at some sites) and appearance in more sites. E3 with reduced subsidence is considered a likely local event. Considering the large error ranges for the bulk peat ages, either E3 or E4 could be correlatives of offshore event $\mathrm{T} 4$, and onshore regional earthquakes recorded at numerous onshore sites. If the smaller event E3 is not regional turbidite T4, it could be either local to the Humboldt area, or could correlate to offshore event T3a, a turbidite limited to southern Cascadia. Humboldt event E5 was considered equivocal by Valentine et al. (2012) based on equivocal and reduced evidence of subsidence, though an event of this age is recorded at all offshore (T5) and numerous onshore sites. Offshore event $\mathrm{T} 5$ is a thick prominent turbidite at all sites south of Rogue Apron. Event E6 is interpreted as occurring between $1750-1900$ cal yr BP, a time when no Cascadia wide earthquake is observed (Goldfinger et al., 2012). Southern Cascadia turbidites T5a and T5b could both potentially be correlative with this subsidence event. T5a is a thin ephemeral bed that is not observed north of Hydrate Ridge, while $\mathrm{T} 5 \mathrm{~b}$ is a robust event interpreted as likely present at all offshore sites south of the Astoria Canyon (Goldfinger et al., 2012). Events of similar age are also observed onshore at Bradley Lake (Kelsey et al., 2005), the Coquille River (Witter et al., 2003), the Sixes River (Kelsey et al., 2002), and the Salmon River (Nelson et al., 2006), all in Oregon, and possibly Johns River, Washington (Shennan et al., 1996). We suggest that Humboldt Bay sites at South Bay and Eel River may have recorded this event. A seventh buried soil (21002700 cal yr BP), may be a correlative of offshore event T6 $(2540 \pm 140$ cal yr BP).

\subsubsection{Cascadia forearc lakes}

A CSZ earthquake of $M_{\mathrm{w}}=9$ would produce severe shaking along the coast, and strong to very strong shaking as far inland as the Cascade Range foothills. Strong motion data from the 2011 Tohoku earthquake recorded values of 1.0-2.0 g at strong motion stations as far as $20-40 \mathrm{~km}$ from the coast (Furumura et al., 2011), comparable to the Cascadia Coast range. Studies of seismic shaking in the inland Cascadia lakes region, however, are limited to just Lake Washington and several cursory searches for liquefaction features (Karlin and Abella, 1992; Karlin et al., 2004). Lake Washington is a large $(22 \mathrm{~km}$ by $5 \mathrm{~km})$, moderately deep, steep-sided lake formed in a glacially carved basin in Puget Sound. Sidescan images show numerous sediment slumps and debris flows, and high-resolution seismic profiles show large retrogressive slope failures. Lake Washington turbidites have magnetic susceptibility signatures that can be correlated throughout the lake, and which have been interpreted as shakinginduced sediment failures. Although one bed (event E) was attributed to a large earthquake (dated to 900-930 AD) on the Seattle Fault (the strands of which underlie Lake Washington), the 300-500 yr recurrence interval and temporal relationship to subduction zone earthquakes known from coastal records, suggest the lake sediments also record subduction zone earthquakes.

Other Cascadia lake sediments from sites west of the Cascade Range have been cored and used extensively for reconstructions of climate, vegetation and fire history (Dearing and Jones, 2003; Briles et al., 2005, 2008; Whitlock et al., 2001, 2008; Long and Whitlock, 2002; Long et al., 2007). Inorganic turbidites have been attributed to increased sediment transport into lakes as a result of post-fire erosion (Millspaugh et al., 2004), meltwater events (C. Briles, personal communication, 2011), increased runoff following severe storms (e.g., Noren et al., 2002), and effects of land clearance and logging roads (Colombaroli and Gavin, 2010). While previous studies were able to use these explanations for minerogenic facies, the lack of consideration of seismicity may simply reflect relatively recent development of the paleoseismic history in western Oregon and Washington.

Our initial examination of core records from southern Cascadia lakes revealed that they contain minerogenic beds (turbidites) that have a similar frequency and timing to the offshore and onshore paleoseismic record of plate boundary earthquakes. We also observe that the geophysical signatures of the lake turbidites in some cases look remarkably similar to the magnetic susceptibility and density signatures of offshore turbidites at similar latitudes in terms of the relative size sequence of the beds, and the individual grain size sequences within each bed (as reflected in the geophysical data). We initially investigated these beds in Sanger Lake, CA, Bolan Lake, OR, which are alpine cirque lakes, and Upper Squaw Lake, a landslide dammed lake, all three of which are near the California/Oregon border (Briles et al., 2008; Colombaroli and Gavin, 2010). We also examined a core from Triangle Lake, Oregon (Gavin and Kusler, unpublished data). The cores from these lakes have a number of ${ }^{14} \mathrm{C}$ ages, and the time series of the inorganic turbidites is also quite compatible with land paleoseismic and turbidite event ages offshore (see Morey et al., 2013). Two of these sites have cores long enough to contain the Mazama ash datum. In detail, we find that the Triangle Lake record most closely resembles that of Hydrate Ridge, which are at similar latitude. Sanger, Bolan and Upper Squaw lakes most closely resemble Rogue, Smith and Klamath cores, also at similar latitudes. By this, we mean the relative magnitude of the magnetic peaks, reflecting the thickness and mineral content of the beds, both for individual beds, and for the bed sequence. For example, the largest bed in the Triangle core is dated at 5930 (5710-6190) cal yr BP, and is massive with two separate fining upward beds and magnetic peaks. Similarly, the largest Cascadia turbidite, T11, is also massive with fining upward sequences (two magnetic peaks) and has a radiocarbon age similar to other Cascadia sites. The sequence of turbidite "sizes" and some individual details of the magnetic profiles are striking for many beds, but not all. For example, the potential equivalents of offshore $\mathrm{T} 9$ and $\mathrm{T} 10$ are weakly expressed in the Triangle Lake core. 
We note that the frequency of larger silt beds in the lake cores for specific time ranges of overlap is very similar to the offshore turbidite record, and that the ${ }^{14} \mathrm{C}$ constrained event sequence is also very similar. The lake records examined thus far also contain thinner beds in many of the same stratigraphic positions occupied by the smaller mud/silt turbidites in the offshore cores (at Hydrate Ridge, Rogue Apron, Smith Canyon, Klamath Canyon and Trinidad Plunge Pool; Fig. 1, Table 4). The four lakes span different time ranges and have different quality and quantity of age control. Table 4 summarizes the time range of the coastal and lake data, the time range investigated in this report, the data source, and the turbidites that may have corresponding offshore equivalents (given as correlated offshore bed names reported in Goldfinger et al., 2012). In total, the four inland lakes contain permissive stratigraphic and temporal equivalents of offshore thin turbidite beds T2b, T2c, T4a, T5a, T5b, T5c, T6a, T10b, T10c, and T10f. We note that the beds with no observed evidence for potential correlatives onshore are among the thinnest and least robust of the offshore turbidites.

In this paper, and in Morey et al. (2013), we propose al alternative mechanism for emplacement of at least some of the observed lake sediment events. We suggest that drainage events move sediment downslope toward the lakes in interseismic times, "reloading" potential lake margin sediment failure zones that may then be triggered during earthquakes (i.e. Dadson et al., 2004, 2005). This process may closely parallel the marine process offshore, where coastal rivers reload the offshore canyon heads simultaneously (Sommerfield and Nittrouer, 1999; Sommerfield and Wheatcroft, 2007; Puig et al., 2004).

The comparisons in Table 4 are preliminary and somewhat qualitative given the range of types of observations and quality of radiocarbon evidence. These preliminary observations are more extensively discussed in Morey et al. (2013), this volume, though improved tests of onshore-offshore correlation await further investigation.

\section{4 "Recording" threshold}

The question of what threshold is required to generate turbidity currents capable of leaving an interpretable stratigraphic record is more complex than simply assessing slope stability. Generating an auto-suspended turbidity current of sufficient volume likely involves not only slope conditions and accelerations, but also the specific slip distribution, frequencies, and directivity of the earthquake, shallow stratigraphy at failure sites, attenuation characteristics of the regional geology, how channelized the delivery system is, as well as long-term sediment supply, recent history of prior earthquakes, and likely other factors. A few historical examples offer clues to this value. Relatively small earthquakes in settings with long recurrence intervals and low attenuation are known to generate large slope failures and turbidity currents (1929 Grand Banks $M_{\mathrm{w}}=7.2$; Heezen and Ewing, 1952; Piper et al.,
1988). More applicable to this paper are turbidity currents known from active margin settings with higher frequencies and high attenuation factors. Accelerations expected from earthquakes of $M_{\mathrm{w}} \sim 7.9$ are known to be sufficient to generate turbidity currents that leave significant turbidites on the abyssal plain in similar lithologies and regional settings based on the turbidite record of the 1906 and prior earthquakes on the northern San Andreas Fault (Goldfinger et al., 2007, 2008). A turbidite associated with the 1952 TokachiOki $M_{\mathrm{w}}=8.1$ earthquake has been identified in the Kushiro fan off Hokkaido (Noda et al., 2008). Two other historical earthquakes, the 1961 and 1973 Nemuro-Oki earthquakes of $M_{\mathrm{w}}=7.2$ and 7.4 respectively were also likely recorded in the Kushiro fan cores as reported by Noda et al. (2008). The PGA (peak ground acceleration) from these earthquakes was also estimated to be less than $0.3 \mathrm{~g}$, providing additional constraints on the recording "threshold" for seismogenic triggering of sufficient strength to be recorded geologically. The 2003 Tokachi-Oki earthquake, also of $M_{\mathrm{w}}=8.3$ occurred slightly landward of the 1952 event, and though it generated a turbidity current recorded at a seafloor observatory (Mikada et al., 2006), an obvious turbidite associated with this event was not observed by Noda et al. (2008).

The $M_{\mathrm{w}}=7.7$ Sanriku-Oki earthquake of 1994 generated turbidity currents sourced from the continental slope that were observed in sediment traps on the lower slope and in the trench. The high lithic sediment fluxes were observed following the earthquake in deep water, when no such flux was observed in shallower water, and at a time when there were no other biogenic "blooms" (Itou et al., 2000). The "high" fluxes of $4.2 \mathrm{~g} / \mathrm{m}^{3} /$ day at a range of $\sim 100 \mathrm{~km}$ from the sediment trap site were very modest however, and likely would not be recorded geologically, at least at that range.

Johnson et al. (2006) report that the Monterey submarine fan records turbidity currents with an average repeat time of $\sim 230 \mathrm{yr}$ (similar to the NSAF, Goldfinger et al., 2008), and a youngest event that may represent the 1906 San Andreas earthquake. The $1989 M_{\mathrm{w}}=7.1$ Loma Prieta earthquake is thought to have generated a turbidity current in the Monterey Canyon based on the transport of up to $1.9 \mathrm{~km}$ and damage caused to a group of moorings located along the canyon axis on a $1.2^{\circ}$ slope (Garfield et al., 1994). The earthquake epicenter was $\sim 50 \mathrm{~km}$ from the site of a rock fall and probable slumping related to generation of the turbidity current, which had an estimated height of $200 \mathrm{~m}$ in deep water. The event almost certainly left a geologic record, though none has yet been reported. The historical evidence available therefore suggests a recording threshold for active margin settings may lie in the range of $M_{\mathrm{w}}=7.0-7.4$, though this is very poorly constrained at present.

In the Supplement, we present a slope stability analysis that bears on the minimum shaking levels required for Cascadia subduction earthquakes, and also present evidence for post- $1700 \mathrm{AD}$ earthquakes. Both of these topics bear directly 
Table 4. Summary comparison of onshore paleoseismic evidence and offshore turbidite stratigraphy.

\begin{tabular}{|c|c|c|c|c|c|}
\hline Site & $\begin{array}{l}\text { Regional turbidite } \\
\text { correlation }\end{array}$ & $\begin{array}{l}\text { Small turbidite } \\
\text { correlation }\end{array}$ & $\begin{array}{l}\text { Offshore Site(s) used } \\
\text { for comparison }\end{array}$ & Time range of data & Time Range investigated \\
\hline $\begin{array}{l}\text { Triangle Lake } \\
\text { D. Gavin (unpublished } \\
\text { data) } \\
\text { Morey et al. (2013) }\end{array}$ & $\begin{array}{l}\mathrm{T} 2^{2}, \mathrm{~T}^{2}, \mathrm{~T} 6^{1}, \mathrm{~T} 7^{1}, \mathrm{~T} 11^{1} \\
\text { further analysis required }\end{array}$ & $\begin{array}{l}\mathrm{T} 4 \mathrm{a}^{2}, \mathrm{~T}_{10 \mathrm{~b}^{2},} \mathrm{~T} 10 \mathrm{c}^{2}, \\
\mathrm{~T} 10 \mathrm{f}^{2} \\
\text { further analysis re- } \\
\text { quired }\end{array}$ & $\begin{array}{l}\text { Hydrate Ridge, Rogue } \\
\text { Apron }\end{array}$ & $0-6000$ cal BP & 0-6000 Cal BP \\
\hline Briles et al. (2005, 2008) & $\begin{array}{l}\text { Bolan lake similar to } \\
\text { Sanger }\end{array}$ & $\begin{array}{l}\text { Bolan lake similar to } \\
\text { Sanger }\end{array}$ & $\begin{array}{l}\text { Rogue Apron, Smith } \\
\text { Canyon, } \quad \text { Klamath } \\
\text { Canyon }\end{array}$ & $0-13000$ cal BP & 0-9800 cal BP \\
\hline $\begin{array}{l}\text { Colombaroli and } \\
\text { Gavin (2010) }\end{array}$ & $\begin{array}{l}\text { further analysis } \\
\text { required }\end{array}$ & $\begin{array}{l}\mathrm{T} 2 \mathrm{~b}^{1}, \quad \mathrm{~T} 2 \mathrm{c}^{1}, \quad \mathrm{~T}^{2} \mathrm{a}^{2}, \\
\mathrm{~T} 5 \mathrm{~b}^{2} \mathrm{~T} 5 \mathrm{c}^{2} \\
\text { further analysis } \\
\text { required }\end{array}$ & $\begin{array}{l}\text { Rogue Apron, Smith } \\
\text { Canyon, } \\
\text { Canyon }\end{array}$ & 0-2000 cal BP & 0-2000 cal BP \\
\hline Briles et al. (2008) & $\begin{array}{l}\mathrm{T}^{1}, \mathrm{~T}^{2}, \mathrm{~T} 4^{2}, \mathrm{~T}^{2}, \mathrm{~T}^{1}, \\
\mathrm{~T}^{1}, \\
\mathrm{~T} 10^{1}, \mathrm{~T} 11^{1}, \mathrm{~T} 13^{1}, \mathrm{~T} 14^{2}, \\
\mathrm{~T} 15^{2} \\
\text { further analysis } \\
\text { required }\end{array}$ & $\begin{array}{l}\text { further analysis } \\
\text { required }\end{array}$ & $\begin{array}{l}\text { Rogue Apron, Smith } \\
\text { Canyon, Klamath } \\
\text { Canyon }\end{array}$ & $0-14000$ cal BP & 0-8900 cal BP \\
\hline Kelsey et al. (2005) & $\begin{array}{l}\mathrm{T}^{3}, \mathrm{~T}^{3}, \mathrm{~T}^{4}, \mathrm{~T}^{3}, \mathrm{~T}^{3}, \\
\mathrm{~T}^{3}, \mathrm{~T}^{4}, \mathrm{~T} 9^{3}, \mathrm{~T} 10^{4} \\
\mathrm{~T} 12^{2}, \mathrm{~T}^{3} 3^{1}\end{array}$ & $\begin{array}{lll}\mathrm{T}_{3} \mathrm{a}^{3}, & \mathrm{~T}_{4 \mathrm{a}^{4},} & \mathrm{~T} 7 \mathrm{a}^{4}, \\
\mathrm{~T} 8 \mathrm{a}^{4}, & \mathrm{~T}^{4} \mathrm{~b}^{4}, & \mathrm{~T} 9 \mathrm{a}^{4}, \\
\mathrm{~T} 10 \mathrm{c}^{3} & & \end{array}$ & $\begin{array}{l}\text { Hydrate Ridge, Rogue } \\
\text { Apron }\end{array}$ & $0-7200$ & $0-7200$ \\
\hline $\begin{array}{l}\text { Coquille River } \\
\text { Witter et al. (2003) } \\
\text { Witter and Kelsey (2004) }\end{array}$ & $\begin{array}{l}\mathrm{T}^{3}, \mathrm{~T}^{3}, \mathrm{~T}^{3}, \mathrm{~T}^{3}, \mathrm{~T}^{3} \\
\mathrm{~T} 9^{3}, \mathrm{~T} 10^{4}, \mathrm{~T} 12^{4}\end{array}$ & $\begin{array}{l}\mathrm{T} 5 \mathrm{~b}^{4}, \quad \mathrm{~T} 8 \mathrm{~b}^{4}, \\
\mathrm{~T} 10 \mathrm{~b}^{3}, \mathrm{~T} 12 \mathrm{a}^{4}\end{array}$ & $\begin{array}{l}\text { Hydrate Ridge, Rogue } \\
\text { Apron }\end{array}$ & $0-6500$ & $0-6500$ \\
\hline $\begin{array}{l}\text { Sixes River } \\
\text { Kelsey et al. (2002) } \\
\text { Witter and Kelsey (2004) }\end{array}$ & $\begin{array}{l}\mathrm{T} 1^{4}, \mathrm{~T}^{3}, \mathrm{~T}^{3}, \mathrm{~T}^{3}, \mathrm{~T}^{3} \\
\mathrm{~T} 9^{3}, \mathrm{~T} 11^{3}\end{array}$ & $\begin{array}{l}\mathrm{T} \mathrm{b}^{3}, \quad \mathrm{~T} 5 \mathrm{c}^{3}, \quad \mathrm{~T} 8 \mathrm{a}^{4} \text { or } \\
\mathrm{T}^{4} \mathrm{~b}^{4}, \mathrm{~T} 9 \mathrm{a}^{4}, \mathrm{~T} 10 \mathrm{~b}^{3}\end{array}$ & $\begin{array}{l}\text { Hydrate Ridge, Rogue } \\
\text { Apron }\end{array}$ & $0-6000$ & $0-6000$ \\
\hline $\begin{array}{l}\text { Humboldt Bay } \\
\text { Valentine et al. (2012) }\end{array}$ & $\begin{array}{l}\text { T1, T2, } \\
\text { possible }^{5}\end{array}$ & T3a, T5b possible ${ }^{5}$ & $\begin{array}{l}\text { Rogue Apron, Trindad } \\
\text { North }\end{array}$ & $0-3500$ & $0-3500$ \\
\hline
\end{tabular}

Notes: ${ }^{1}$ probable, see Morey et al. this volume. ${ }^{2}$ possible, see Morey et al. (2013). ${ }^{3}$ probable based on age overlap and relative size comparison. Most of these events pass $X^{2}$, Acomb and Amodel Oxcal criteria when onshore and offshore ages are combined. See Goldfinger et al. (2012) comparison matrix, their Appendix 11. ${ }^{4}$ possible based on age overlap and relative size comparison. See Goldfinger et al. (2012) comparison matrix for Bradley, Sixes and Coquille sites, their Appendix $11 .{ }^{5}$ possible, based on overlapping radiocarbon ages only.

on the issue of recording threshold and completeness of the Cascadia paleoseismic record.

\subsection{Implications}

A primary observation that segmented earthquake ruptures occur primarily in southern Cascadia, with variable northern (and probably southern) limits, is supported by the additional new data presented here. Ruptures interpreted to terminate at or near Rogue Apron include T2a, T6a, T6b, T7a, T8a, (or T8b), T9b, T10d, and T15a. These beds are among the faintest in our records at Rogue, though we now interpret T2a, T8a, T8b, and T9b to coarsen southward. Eight ruptures likely terminate near Hydrate Ridge: T3a, T4a, T5a, T5c, T10a, T10c, T10d, possibly T10f, T12a, T14a, T16a and
T16b. These ruptures are interpreted to appear in both Rogue Apron and Hydrate Ridge cores, but do not appear in Astoria Channel cores. All of these beds coarsen south of Rogue Apron. Three or four ruptures that may extend north of Hydrate Ridge include T5b, T9a, T8a or b, and T10f, but we are unable to determine the limits for these beyond Hydrate Ridge with confidence.

The southern limits of many of the correlated mud turbidites remain difficult to determine with existing data. Figure 8 substantially improves the southern margin correlations over those presented in Goldfinger et al. (2012), but are still largely limited to times later than $\mathrm{T} 11(\sim 5900 \mathrm{cal} \mathrm{yr} \mathrm{BP})$. New cores TN0909-09 and 10 JC, and 1999 core M9907$41 \mathrm{PC}$ in the Eel Channel contain a number of additional turbidites and an expanded section. Work on these cores 
is ongoing; as of this writing, we observe that they have greatly expanded sections and additional uncorrelated turbidites. While these cores very likely include earthquake records, they may also include storm input from the Eel River (e.g., Puig et al., 2004), and potentially could include evidence of Gorda Plate, Mendocino Fault, and northern San Andreas earthquakes as well. These 2009 cores will help clarify the southern Cascadia record further, but further analysis is required.

The generation of similar phenomena in a number of different environments in response to great earthquakes should not be surprising. What is surprising is the apparent fidelity with which past earthquakes may have been recorded. Cores from Effingham Inlet off Vancouver Island, British Columbia, Canada, (Dallimore et al., 2005, 2009; Enkin et al., 2013) are similarly striking. The Effingham studies interpret a number of seismites in marine cores, based on the distinct wall rock signature from the fjord walls and the fining upward distinctive turbidite signature, as compared to the background sedimentation. They identified and dated the deposit from the 1946 Vancouver Island $M_{\mathrm{w}}=7.2$ earthquake, and a number of other Holocene seismites. Physical property, "wiggle match", correlations of six of the Effingham Inlet beds and turbidites of compatible age in our Cascadia Channel cores are shown in Goldfinger et al. (2012). A strong stratigraphic signature common to both nearshore and offshore cores, and, in some cases, lake deposits (Morey et al., 2013) is apparent, as well as a correspondence of relative thickness of the beds downcore, again supported by compatible age control. We believe that this evidence lends strong support to an earthquake shaking "signature" as the common link between these fjord, lake and offshore cores (Goldfinger et al., 2011, 2012). Preliminary field evidence and experimental results that address the hypothesis of recording of the earthquake source signatures in turbidite deposits is reported in Goldfinger et al. (2011, 2012) and Garrett et al. (2011).

The evidence for coarsening of many (but not all) of the Rogue Apron turbidite beds southward may have one or more causes. Southward increasing sediment supply could be a factor in the observed trend. The high sediment discharge from the Eel and Klamath-Trinity river systems, and subsequent northwesterly transport of this material during the storm season is consistent with recharge of the upper canyon reaches for the Trinidad, Klamath and Smith canyon systems (Griggs and Hein, 1980; Sommerfield and Wheatcroft, 2007). The northward diminishing plume is also consistent with the thinning of the Holocene section and is generally consistent with a thinner Holocene section at Klamath Canyon, but fails to explain the overall thicker section in the area of Smith Canyon. The present sediment discharge of the Smith River is roughly an order of magnitude smaller than the Klamath River $\left(\sim 3.3 \times 109 \mathrm{~kg} \mathrm{yr}^{-1}\right.$ vs. $0.4 \times 109 \mathrm{~kg} \mathrm{yr}^{-1}$; Wheatcroft and Sommerfield, 2005; California Beach Restoration Study, 2002), opposite to the trend observed offshore. The present difference might be attributed to modern anthropogenic activity (Holmquist-Johnson and Milhous, 2010), mixing of sources on the abyssal plain, or other causes.

The observation that some of the Rogue turbidites thin and fine southward while others coarsen, suggests that sediment supply and delivery are not the only factors involved in thickness and grain size trends in southern Cascadia. Considering the seven core sites shown in Fig. 8, regionally correlated beds $\mathrm{T} 2, \mathrm{~T} 3, \mathrm{~T} 5$, and $\mathrm{T} 9$ increase in thickness, density, and grain size southward, to a greater degree than the regional trend. Conversely, regional beds T4, T6, T7, T8, T11, and T16 diminish southward. While many turbidites coarsen southward, most do not thicken southward as we initially expected, though some do (Supplement, Table S4 and Fig. S1). The consistency of this observation across several depositional systems suggests that the energetics of the triggering earthquakes (or other causes) may play a role as well. Goldfinger et al. $(2008,2012)$ proposed the Cape Blanco area as a seismic and structural segment boundary based on the paleoseismic evidence onshore and offshore, and the subduction of significant topographic features (the Blanco Fracture Zone and a nearby rift propagator that has been reactivated as a compressional structure, Chaytor et al., 2004). Other investigators have proposed a segment boundary at essentially the same location based on geodetics and the location of the Klamath-Siletzia terrane boundary (Burgette et al., 2009). If the Cape Blanco area is a persistent seismic segment boundary, we suggest that area may have reduced slip during earthquakes that terminate there as well as those that jump the boundary, similar to the observations at the persistent segment boundary between the 2004-2005 Sumatran earthquakes at Simeulue Island (Meltzner et al., 2012). Meltzner et al. (2012) have shown that slip drops to very low values at the segment boundary, which is exposed on Simeulue Island. If correct, this reduced shaking and subsequent sediment transport downslope may account for the local thinning of the Holocene section at Rogue Apron, despite the presence of a major submarine canyon. This is particularly striking considering that the Holocene section actually thickens toward the minor Smith Canyon, and away from Rogue Canyon which is a major drainage of the southern Cascadia margin. Alternatively, this observation could be due to pre-existing abyssal topography. Similarly, we also suggest that the trends in bed coarseness and in particular the trends in bed thickness that are discordant with the regional trend could represent real trends in the slip distribution of those earthquakes. The beds that trend in the opposite sense to the regional thickness and grain size trends (T1, T4, T6, T7, T8, $\mathrm{T} 11$, and T16) are the most convincing of this potential effect, suggesting that the source earthquakes may have terminated or lost energy to the south relative to values at Rogue Apron, despite the southward increase in sediment supply.

The average recurrence time for southern Cascadia earthquakes is $\sim 240 \mathrm{yr}$ throughout the Holocene, half of the average recurrence time along the northern margin (Goldfinger 
et al., 2012). This should probably be considered a maximum average given the additional turbidites in the record that presently are not interpreted. Witter et al. (2012) discuss modeling of tsunami using the earthquake sources from Goldfinger et al. (2012), which are further supported in this study. They find that the recurrence times are somewhat shorter than required to generate tsunami that reach Bradley Lake, a requirement of the models. They present a detailed rationale for testing of a variety of slip models and landscape configurations, and suggest two explanations for this: (1) complex partial ruptures in the vicinity of Rogue Canyon, and (2) stored energy from longer-term cycling of potential energy. While we do not address this issue directly in this study, we refer the reader to fuller discussion of these two hypotheses in Witter et al. (2012) and Goldfinger et al. (2013).

The evidence of plate boundary earthquakes in southern Cascadia now potentially includes one barrage lake, three marsh sites, four inland lakes and numerous deep water cores. Among the coastal sites at Bradley Lake, Coquille River, Sixes River, and the Humboldt Bay area, temporal equivalents exist for 10 of a possible 16 correlated thin beds, potentially representing $\sim 63 \%$ of the offshore earthquakes for the period 0-6000 yr BP. at similar latitudes (Table 4). Of these 10, four are inferred at one site, and four at two sites, and two are evident at three sites. Considering the preliminary lake evidence described in detail by Morey et al. (2013) we include a number of lake beds that we consider to have sufficient temporal or geophysical evidence of synchronous deposition compared to onshore and offshore paleoseismic sites in Table 4. The four inland lakes cover different time ranges, with only one of them (Sanger Lake) spanning the full time range considered here $(0-6000 \mathrm{cal}$ yr BP $)$. The aggregate of the most robust temporal equivalents includes 15 of the 16 (19 if we include T2b, T2c, and T9c) thin beds at for that period. Five of these 15 events are found in the inland lakes but are not represented at coastal sites, while 10 are potentially present at both. Considering all eight coastal and inland sites, we infer that earthquake evidence may be present for 16 of 19 (including T2b, T2c and T9c in the total count) events in this period, or $84 \%$ of all offshore seismoturbidites (Table 4). Of these 16 events, Table 4 suggests that six may be evident at one site, seven may be evident at two sites, two may be evident at three sites, and one (T5b)may be evident at four sites. The aggregate of all land sites may include records of equivalent of $88 \%$ of the marine record for southern Cascadia. Presently, not enough evidence exists from central and northern Cascadia lakes and onshore paleoseismic sites to corroborate northward terminations interpreted from the existing onshore-offshore evidence (Goldfinger et al., 2012).

\section{Conclusions}

New cores collected in 2009 enhance the interpretation of the southern Cascadia deep water turbidite record during the latter half of the Holocene. The southern Cascadia margin turbidite sequence includes at least 23 turbidites that do not correlate along the full length of the margin, but may be correlated along variable sections of the southern margin over distances of 100-300 km. The new cores sample the southern Cascadia margin across seven core sites on the abyssal plain and one isolated slope basin. All but two of the 23 turbidites are composed of thinner, mud-silt beds at Rogue Apron, with the remaining two being sandy turbidites. The beds at Rogue Apron are characterized by subtle grain-size variation and visual color change, subdued physical-property signatures, greater bioturbation, and greater variability between core sites. The primary characteristics of the beds are grain size profiles that indicate sharp bases and fining upward sequences, based on gamma and CT density and magnetic susceptibility grain size proxies. Fifteen of 21 correlated thin beds have these dominant characteristics. The remaining six (T7a, T8b, T9b, T12a, T16a, T16b) are equivocal or indeterminate due to bioturbation, core section breaks, sample voids from previous work, and core deformation. We observe no beds that have clearly coarsening upward, or coarsening upward and then fining upward profiles (suggestive of hyperpycnites) indicated by multiple proxies. The thin beds are not as consistent in their characteristics as the larger sandy turbidites and not as self-consistent across the local core group at Rogue Apron. The thin turbidites include sponge spicules sourced from mid-slope depths, giving evidence of material transport from the continental slope as opposed to shallow water sources. Lithostratigraphic correlation with radiocarbon age support between Rogue Apron and Trinidad Plunge Pool, $150 \mathrm{~km}$ to the south, suggests that the Rogue mud turbidites coarsen southward. Of the 13 thin beds younger than $\sim 4800$ cal yr BP at Rogue Apron, we tentatively correlate nine of them between the two sites, though beds younger than $\sim 3500$ cal yr BP are difficult to interpret across an area of reduced sedimentation near Smith and Klamath Canyons during that time. Four beds, T4a, T6a, T6b, and T7a, cannot be directly linked across this thin region, though beds in equivalent stratigraphic positions for T4a and T6a are present at Rogue Apron and Trinidad Plunge Pool. Of the 11 potential correlative beds, 8 of them coarsen southward to sandy-silty grain size in their basal units and are visible in the cores, while the remaining three are interpreted from CT data. An additional six beds appear in the section older than AD 1700 and younger than $4800 \mathrm{cal} \mathrm{yr} \mathrm{BP}$ between Rogue Apron and Trinidad Plunge Pool. The six mostly sandy beds have sharp bases and fining upward sequences, but are not correlated over large enough distances or linked to onshore paleoseismic sites, thus their origin is indeterminate. Beds older than $\sim 4800$ cal yr BP are tentatively correlated in some cases, or are either not sampled in the cores or do not have sufficient age control for stratigraphic correlation.

Examination of the seismic stratigraphy of the southern Cascadia margin reveals a remarkably consistent turbidite dominated sequence that can be directly correlated to the 
abyssal plain piston core stratigraphy. Regional turbidites are imaged with these high-resolution Chirp data. Although the thin mud turbidites are not imaged directly, several thick intervals that are occupied by series of mud turbidites at Rogue Apron can be traced regionally by their constant thickness. The regional continuity of these intervals implies that the interbedded thin turbidites are also likely present, consistent with the intercore observations.

The total mass of turbidites deposited at four Cascadia core sites is similar within a narrow range, even though the northern margin Holocene sequence is thinner by a factor of $\sim$ two than the southern margin sequence. Hemipelagic sedimentation rates are also regionally consistent, leaving this disparity in overall thickness attributable to the sequence of 23 mud turbidites present along the southern margin.

Slope stability assessments suggest that unconsolidated materials on slopes along the southern Cascadia margin would likely fail in earthquakes of $M_{\mathrm{w}}=7.0$ or greater, lower than the values predicted for southern Cascadia segmented earthquakes based on estimated slip, area and interevent time. The likely ground accelerations from segmented southern Cascadia earthquakes are therefore sufficient to generate turbidity currents. Sparse historical evidence suggests the magnitude threshold for generating an interpretable geologic record may be in the range of $M_{\mathrm{w}}=7.0$ 7.4 for subduction settings with high attenuation of highfrequency seismic waves.

Cores at and south of Rogue Apron include two to three young turbidites emplaced following the $1700 \mathrm{AD}$ plate boundary earthquake. These turbidites contain $\mathrm{Pb} 210$ excess activity, indicating emplacement younger than $\sim 150 \mathrm{yr}$, and the uppermost two include bomb contaminated carbon radionuclides, indicating post 1952 emplacement. Although the origin of these beds cannot be tied directly to historic events with present data, the three beds could represent the strongest historic earthquakes known in the area, the 1873, 1980 and 1992 southern Cascadia earthquakes, though many other possibilities exist.

Potential correlative turbidites, subsided marshes and tsunami sand sheets are found among five onshore lakes and three marsh localities in southern Cascadia. Preliminary investigations suggest that $80-90 \%$ of the offshore seismoturbidite events may be represented collectively at these sites over the past $6000 \mathrm{yr}$.

While the tests for regional synchroneity are not as strong for the spatially limited turbidites of southern Cascadia as they are for the major regional beds, the data support a seismic origin based on seismic stratigraphic correlation, lithostratigraphic correlation, sedimentology, deep water source, and supportive radiocarbon data. Though of more limited extent, the proposed plate boundary earthquakes are interpreted to have generated correlative beds in the isolated Hydrate Ridge piggyback basin, a coastal lake, and possibly in four inland lakes. A variable number of diagnostic attributes is available for each bed. Alternative sources are not consistent with low event frequency, intersite correlation, or sedimentology of the deposits. If the seismic origin is correct, the turbidite sequence supports a model of segmented Cascadia margin earthquake ruptures limited to three or possibly more segments along the southern Cascadia margin.

\section{Supplementary material related to this article is available online at: http://www.nat-hazards-earth-syst-sci.net/13/2109/2013/ nhess-13-2109-2013-supplement.zip.}

Acknowledgements. The manuscript has greatly benefitted from thoughtful reviews by Geoffroy Lamarche, Alan Orpin and Antonio Cattaneo, with helpful comments on ground motions from Art Frankel. We thank Michaele Kashgarian (Lawrence Livermore AMS Facility) and John Southon (Keck AMS facility, University of California, Irvine) for running the majority of the AMS radiocarbon dates and their assistance with many radiocarbon issues. We thank the officers and crews of the R/V Melville, R/V Thompson and $\mathrm{R} / \mathrm{V}$ Revelle who provided excellent ship handling and coring logistics for the field work. The coring techniques of Pete Kalk, Chris Moser, Bob Wilson and Chuen-Chi "Charles" Liu provided the superb piston cores that are necessary for paleoseismic analysis. We also thank Morgan Erhardt, Jeff Beeson, Tim Kane, Amy Garrett and the shipboard scientific parties for help with data acquisition, analysis, graphics and help at sea.

The initial funding for this study was provided by the Coastal and Marine Geology Team of the US Geological Survey. The primary funding for field work and subsequent research has been provided by NSF Awards EAR 9803081 EAR-0001074, EAR-0107120, EAR-0440427 and OCE-0550843 (reservoir model development) and OCE 0850931 (2009 cruise). US Geological Survey substantially supported the work through Cooperative Agreements 6-7440-4790, 98HQAG2206 and 99HQAG0192; and US Geological Survey National Earthquake Hazard Reduction Program grants 02HQGR0019, 03HQGR0037, 06HQGR0149, and 07HQGR0064 to Goldfinger, and 02HQGR0043, 03HQGR0006, and 06HQGR0020 to Nelson. The American Chemical Society awarded support to $\mathrm{PhD}$ student Joel Johnson for core collection and analysis at Hydrate Ridge under ACS PRF 37688-AC8. This paper has also benefitted from comments and discussion at a workshop convened at Oregon State University on 18-19 November 2010 for the purpose of reviewing turbidite paleoseismic data. The participants in this workshop were: Arthur Frankel, John Vidale, Ray Weldon, Alan Nelson, Brian Atwater, Brian Sherrod, Craig Weaver, Ned Field, Gary Carver, C. Crouse, Ivan Wong, Mark Petersen, Roland LaForge, Vicki McConnell, Tim Walsh, Ian Madin, Rob Witter, Harvey Kelsey, Paul Johnson, Larry Phillips, Ben Sheets, Joanne Bourgeois, Chesley Williams, Jake Covault, Gordon Seitz, Paul Bodin, Robert Yeats, Guillaume St-Onge, Yumei Wang, and Ray Wells. Their listing here does not constitute endorsement on their part.

Edited by: G. Lamarche

Reviewed by: A. Cattaneo and A. Orpin 


\section{References}

Abdeldayem, A. L., Ikehara, K., and Yamazaki, T.: Flow path of the 1993 Hokkaido-Nansei-oki earthquake seismoturbidite, southern margin of the Japan sea north basin, inferred from anisotropy of magnetic susceptibility: Geophys. J. Int., 157, 15-24, 2004.

Abrams, L. J.: Correlation among core, logging, and seismic data at Site 1149 in the Nadezhda Basin, edited by: Ludden, J. N., Plank, T., and Escutia, C., Proc. ODP, Sci. Results, 185, available at: http://www-odp.tamu.edu/publications/185_SR/001/001.htm (last access: 9 September 2012), 2002.

Adams, J.: Paleoseismicity of the Cascadia subduction zone: evidence from turbidites off the Oregon-Washington margin, Tectonics, 9, 569-583, 1990.

Anastasakis, G. C. and Piper, D. J. W.: The character of seismoturbidites in the S-1 sapropel, Zakinthos and Strofadhes basins, Greece, Sedimentology, 38, 717-733, 1991.

Awadallah, S. A. M.: Fine-grained turbidites of the Amazon Fan: facies characterization and interpretation, edited by: Taylor, B. and Klaus, A., Proc. ODP, Sci. Results, 180, 1-30, 2001.

Azmon, E.: Use of clay fabric to distinguish turbidites from hemipelagic siltstone, Sedimentology, 28, 733-735, 1981.

Barnard, W. D.: Late Cenozoic sedimentation on the Washington continental slope [PhD Thesis], University of Washington, 255 pp., 1973.

Bernd, Z., Jens, M., van der Gaast, S., Jansen, J., and Naumann, R.: Sediment logging techniques, in: Tracking Environmental Change Using Lake Sediments Basin Analysis, Coring, and Chronological Techniques, edited by: Last, W. M. and Smol, J. P., Springer Netherlands, 1, 137-153, 2002.

Bett, B. J. and Rice, A. L.: The influence of hexactinellid sponge (Pheronema carpenteri) spicules on the patchy distribution of macrobenthos in the Porcupine Seabight (bathyal NE Atlantic), Ophelia, 36, 217-226, 1992.

Blais-Stevens, A., Rogers, G. C., and Clague, J. J.: A revised earthquake chronology for the last 4000 years inferred from varvebounded debris-flow deposits beneath an inlet near Victoria, British Columbia, Bull. Seism. Soc. Am., 101, 1-12, 2011.

Blott, S. J. and Pye, K.: Particle size distribution analysis of sandsized particles by laser diffraction - An experimental investigation of instrument sensitivity and the effects of particle shape, Sedimentology, 53, 671-685, 2006.

Briles, C. E., Whitlock, C., and Bartlein, P. J.: Postglacial vegetation, fire, and climate history of the Siskiyou Mountains, Oregon, USA, Quaternary Res., 64, 44-56, 2005.

Briles, C. E., Whitlock, C., Bartlein, P. J., and Higuera, P.: Regional and local controls on postglacial vegetation and fire in the Siskiyou Mountains, northern California, USA, Palaeogeog. Palaeoclim. Palaeoecol., 265, 159-169, 2008.

Brocher, T. M.: Empirical Relations between Elastic Wavespeeds and Density in the Earth's Crust, Bull. Seism. Soc. Am., 95, 2081-2092, 2005.

Brunner, C. A. and Ledbetter, M. T.: Hydraulic sorting of foraminifers in visually undetected turbidites in late Pleistocene sediments of Monterey Fan on the Central California continental margin, The Geol. Soc. of Am., 98th annual meeting Abstracts with Programs - Geol. Soc. of Am., 17, Orlando, FL United States, 533, 1985.

Brunner, C. A. and Ledbetter, M. T.:, Sedimentological and micropaleontological detection of turbidite muds in hemipelagic sequences; an example from the late Pleistocene levee of Monterey Fan, Central California continental margin, Mar. Micropaleo., 12, 223-239, 1987.

Brunner, C. A. and Ledbetter, M. T.: Late Quaternary quantitative planktonic foraminiferal biostratigraphy in turbidite sequences of the Central California continental margin, Micropaleo., 35, 321336, 1989.

Brunner, C. A. and Normark, W. R.: Biostratigraphic implications for the turbidite depositional processes on the Monterey deep-sea fan, Central California, J. Sediment. Pet., 55, 495-505, 1985.

Burgette, R. J., Weldon II, R. J., and Schmidt, D. A.: Interseismic uplift rates for western Oregon and along-strike variation in locking on the Cascadia subduction zone, J. Geophys. Res., 114, B01408, doi:10.1029/2008JB005679, 2009.

California Department of Boating and Waterways and State Coastal Conservancy, California Beach Restoration Study, Sacramento, California, 280 pp., 2002.

Carson, B.: Stratigraphy and depositional history of Quaternary sediments in northern Cascadia Basin and Juan de Fuca abyssal plain, northeast Pacific Ocean [Ph. D thesis], University of Washington, 249 pp., 1971.

Chapron, E., Ariztegui, D., Mulsow, S., Villarosa, G., Pino, M., Outes, V., Juvignié, E., and Crivelli, E.: Impact of the 1960 major subduction earthquake in Northern Patagonia (Chile, Argentina), Quaternary Int., 158, 58-71, 2006.

Chaytor, J. D., Goldfinger, C., Dziak, R. P., and Fox, C. G.: Active deformation of the Gorda plate: Constraining deformation models with new geophysical data, Geology, 32, 353-356, 2004.

Chen, Y., Hur, H., Leigh, J., Johnson, A., Renambot, L., Ito, E., Morin, P., Higgins, S., and Reed, J.: The CoreWall Project Core Visualization, Stratigraphic Correlation and Rich Media Distribution, Workshop on the Future of Continental Scientific Drilling, a US Perspective, Denver, Colorado, June 2009.

Cita, M. B. and Aloisi, G.: Deep-sea tsunami deposits triggered by the explosion of Santorini (3500 yr BP), eastern Mediterranean, Sediment. Geol., 135, 181-203, 2000.

Colombaroli, D. and Gavin, D. G.: Highly episodic fire and erosion regime over the past 2,000 y in the Siskiyou Mountains, Oregon, Proc. Natl. Acad. Sci., 107, 18909-18914, 2010.

Curran, K. J., Hill, P. S., Schell, T. M., Milligan, T. G., and Piper, D. J. W.: Inferring the mass fraction of floc-deposited mud: application to fine-grained turbidites, Sedimentology, 51, 927-944, 2004.

Dadson, S. J., Hovius, N., Chen, H., Dade, W. B., Lin, J. C., Hsu, M. L., Lin, C. W., Horng, M. J., Chen, T.-C., Milliman, J., and Stark, C. P.: Earthquake-triggered increase in sediment delivery from an active mountain belt, Geology, 32, 733-736, 2004.

Dadson, S. J., Hovius, N., Pegg, S., Dade, W. B., Horng, M. J., and Chen, H.: Hyperpycnal flows from an active mountain belt, J. Geophys. Res., 110, F04016, doi:10.1029/2004JF000244, 2005.

Dallimore, A., Thomson, R. E., and Bertram, M. A.: Modern to late Holocene deposition in an anoxic fjord on the west coast of Canada: Implications for regional oceanography, climate and paleoseismic history, Mar. Geol., 219, 47-60, 2005.

Dallimore, A., Enkin, R. J., Baker, J., and Peinitz, R.: Stratigraphy and late Pleistocene-Holocene history of Effingham Inlet, BC, Results from MONA Core MD02-2494 and GSC freeze cores, Geological Survey of Canada Open-File Report 5930, 2009. 
Dearing, J. A. and Jones, R. T.: Coupling temporal and spatial dimensions of global sediment flux through lake and marine sediment records, Glob. Planet. Change 39, 147-168, 2003.

Einsele, G. and Kelts, K.: Pliocene and Quaternary Mud Turbidites in the Gulf of California: Sedimentology, Mass Physical Properties, and Significance, edited by: Moore, D. G. and Curray, J. R., Init. Rep. DSDP, 64, Washington, DC, US Govt. Printing Office, 511-528, 1982.

Enkin, R. J., Dallimore, A., Baker, J., Southon, J. R., and Ivanochko, T.: A new high-resolution radiocarbon Bayesian age model of the Holocene and Late Pleistocene from core MD02-2494 and others, Effingham Inlet, British Columbia, Canada; with an application to the paleoseismic event chronology of the Cascadia Subduction Zone, Can. J. Earth Sci., 50, 746-760, 2013.

Fukuma, K.: Origin and applications of whole-core magnetic susceptibility of sediments and volcanic rocks from Leg 152, Proc. ODP, Sci. Results, 152, 271-280, 1998.

Furumura, T., Takemura, S., Noguchi, S., Takemoto, T., Maeda, T., Iwai, K., and Padhy, S.: Strong ground motions from the 2011 off-the Pacific-Coast-of-Tohoku, Japan $(\mathrm{Mw}=9.0)$ earthquake obtained from a dense nationwide seismic network, Landslides, 8, 333-338, 2011.

Garfield, N., Rago, T. A., Schnebele, K. J., and Collins, C. A.: Evidence of a turbidity current in Monterey Submarine Canyon associated with the 1989 Loma Prieta earthquake, Cont. Shelf Res., 14, 673-686, 1994.

Garrett, A., Goldfinger, C., Paton, J., and Morey, A.: Paleoseismograms: Testing a Hypothesis of Source-Time Function Recording of Paleoearthquakes, AGU Fall Meeting, Abstract T51F-2421, Eposter, available at: http://activetectonics.coas.oregonstate.edu/ paper_files/posters/garrettagu_poster_final.pdf, 2011.

Goldfinger, C.: Subaqueous Paleoseismology, in: Paleoseismology, edited by: McAlpin, J. P., International Geophysics Series, 95, Amsterdam, Elsevier, 119-170, 2009.

Goldfinger, C.: Possible turbidite record of earthquake source characteristics: a small scale test, NEHRP Annual Report, 34, Reston, VA, US Geological Survey, 18 pp., 2011.

Goldfinger, C., Nelson, C. H., and Johnson, J. E.: Deep-water turbidites as Holocene earthquake proxies: The Cascadia Subduction Zone and northern San Andreas fault systems, Ann. Geofis., 46, 1169-1194, 2003a.

Goldfinger, C., Nelson, C. H., and Johnson, J. E.: Holocene earthquake records from the Cascadia Subduction Zone and northern San Andreas fault based on precise dating of offshore turbidites, Ann. Rev. Earth Plan. Sci., 31, 555-577, 2003b.

Goldfinger, C., Morey, A. E., Nelson, C. H., Gutierrez-Pastor, J., Johnson, J. E., Karabanov, E., Chaytor, J., and Ericsson, A.: Rupture lengths and temporal history of significant earthquakes on the offshore and north coast segments of the northern San Andreas fault based on turbidite stratigraphy, Earth Planet. Sci. Lett., 254, 9-27, 2007.

Goldfinger, C., Grijalva, K., Burgmann, R., Morey, A. E., Johnson, J. E., Nelson, C. H., Gutierrez-Pastor, J., Karabanov, E., Chaytor, J. D., Patton, J., and Gracia, E.: Late Holocene Rupture of the Northern San Andreas Fault and Possible Stress Linkage to the Cascadia Subduction Zone, Bull. Seis. Soc. Am., 98, 861-889, 2008.

Goldfinger, C., Nelson, C. H., Morey, A., Johnson, J. E., Patton, J., Karabanov, E., Gutierrez-Pastor, J., Eriksson, A. T., Gracia, E.,
Enkin, R., Dallimore, A., Dunhill, G., and Vallier, T.: Turbidite Event History: Methods and Implications for Holocene Paleoseismicity of the Cascadia Subduction Zone, US Geological Survey Professional Paper 1661-F, Reston, VA, US Geological Survey, 184 pp., 64 Figures, 2012.

Goldfinger, C., Ikeda, Y., Yeats, R. S., and Ren, J.: Superquakes and Supercycles, Seismol. Res. Lett., 84, 24-32, 2013.

Griggs, G. G. and Hein, J. R.: Sources, Dispersal, and Clay Mineral Composition of Fine-Grained Sediment off Central and Northern California, J. Geol., 88, 541-566, 1980.

Heezen, B. C. and Ewing, M.: Turbidity currents and submarine slumps, and the 1929 Grand Banks earthquake, Am. J. Sci., 250, 849-873, 1952.

Henkart, P.: Chirp Sub-Bottom Profiler Processing - A review: Sea Technology, Compass Publications, 35-38, 2006.

Hesse, R.: Turbiditic and non-turbiditic mudstone of Cretaceous flysch sections of the eastern Alps and other basins, Sedimentology, 22, 387-416, 1975.

Holmquist-Johnson, C. L. and Milhous, R. T.: Channel maintenance and flushing flows for the Klamath River below Iron Gate Dam, California, US Geological Survey Open File Report 2010-1086, 31 pp., 2010.

Hughen, K. A., Baillie, M. G. L., Bard, E., Bayliss, A., Beck, J. W., Blackwell, P. G., Buck, C. E., Burr, G. S., Cutler, K. B., Damon, P. E., Edwards, R. L., Fairbanks, R. G., Friedrich, M., Guilderson, T. P., Herring, C., Kromer, B., McCormac, F. G., Manning, S. W., Ramsey, C. B., Reimer, P. J., Reimer, R. W., Remmele, S., Southon, J. R., Stuiver, M., Talamo, S., Taylor, F. W., van der Plicht, J., and Weyhenmeyer, C. E.: Marine04 Marine radiocarbon age calibration, 26-0 ka BP, Radiocarbon, 46, 1059-1086, 2004.

Inouchi, Y., Kinugasa, Y., Kumon, F., Nakano, S., Yasumatsu, S., and Shiki, T.: Turbidites as records of intense palaeoearthquakes in Lake Biwa, Japan, Sediment. Geol., 104, 117-125, 1996.

Itou, M., Matsumura, I., and Noriki, S.: A large flux of particulate matter in the deep Japan Trench observed just after the 1994 Sanriku-Oki earthquake, Deep Sea Res. Part I, 47, 1987-1998, 2000.

Iwaki, H., Hayashida, A., Kitada, N., Ito, H., Suwa, S., and Takemura, K.: Stratigraphic correlation of samples from the Osaka Bay off Kobe based on magnetic properties and its implication for tectonic activity of the Osaka-wan fault for the last 6300 years, Eos Trans. Am. Geophys. Union, 84, GP41C-0053 F554, 2004.

Johnson, J. E.: Deformation, fluid venting, and slope failure at an active margin gas hydrate province, Hydrate Ridge, Cascadia accretionary wedge [PhD thesis], Corvallis, Oregon State University, 2004.

Johnson, J. E., Paull, C. K., Normark, W. R., and Ussler, W.: The extent and recurrence of Holocene turbidity currents in Monterey Canyon and fan channel, offshore California [abstract], Eos, Trans. Am. Geophys. Union, 87, Fall Meeting Supplement, Abstract OS14A-06, 2006.

Joseph, L. H., Rea, D. K., and van der Pluijm, B. A.: Use of grain size and magnetic fabric analyses to distinguish among depositional environment, Paleoceanography, 13, 491-501, 1998.

Karlin, R. C. and Abella, S. E. B.: Paleoearthquakes in the Puget Sound region recorded in sediments from Lake Washington, USA, Science, 258, 1617-1620, 1992. 
Karlin, R. E., Holmes, M., Abella, S. E. B., and Sylwester, R.: Holocene landslides and a 3500-year record of Pacific Northwest earthquakes from sediments in Lake Washington, Geol. Soc. Am. Bull., 116, 94-108, 2004.

Kastens, K. A.: Earthquakes as a triggering mechanism for debris flows and turbidites on the Calabrian Ridge, Mar. Geol., 55, 1333, 1984.

Kelsey, H. M. and Witter, R.: Final Technical Report: Middle to Late Holocene Earthquake Chronologies for the Cascadia Subduction Zone from Two Estuaries in Southern Oregon: Collaborative Research with William Lettis \& Associates, Inc. and Humboldt State University, Final Technical Report, USGS National Earthquake Hazard Reduction Program, Reston, VA, U.S.G.S., 40 pp., 2004.

Kelsey, H. M., Witter, R. C., and Hemphill-Haley, E.: Plateboundary earthquakes and tsunamis of the past $5500 \mathrm{yr}$., Sixes River estuary, southern Oregon, Geol. Soc. Am. Bull., 114, 298314, 2002.

Kelsey, H. M., Nelson, A. R., Hemphill-Haley, E., and Witter, R. C.: Tsunami history of an Oregon coastal lake reveals a 4600 yr. record of great earthquakes on the Cascadia subduction zone, Geol. Soc. Am. Bull., 117, 1009-1032, 2005.

Long, C. J. and Whitlock, C.: Fire and Vegetation History from the Coastal Rain Forest of the Western Oregon Coast Range, Quaternary Res., 58, 215-224, 2002.

Long, C., Whitlock, C., and Bartlein, P.: Holocene vegetation and fire history of the Coast Range, western Oregon, USA, Holocene, 17, 917-926, 2007.

Lovlie, R. and Van Veen, P.: Magnetic susceptibility of a $180 \mathrm{~m}$ sediment core: reliability of incremental sampling and evidence for a relationship between susceptibility and gamma activity, in: Palaeomagnetic applications in hydrocarbon exploration and production, edited by: Turner, P. and Turner, A., Special Publication, 98, Geological Society, London, 259-266, 1995.

Ludwig, W. J., Nafe, J. E., and Drake, C. E.: Seismic refraction, in: The Sea, edited by: Maxwell, A. E., 4, Wiley-Interscience, New York, 53-84, 1970.

Lyle, M. E., Mix, A., Ravelo, C., Andreasen, D., Heusser, L., and Olivarez, A.: Millenial scale $\mathrm{CaCO}_{3}$ and Corg events along the northern and central California margin: stratigraphy and origins, Ocean Drilling Program Revision for Proceedings of the Ocean Drilling Program Science Results Paper 167S-214, 1999.

McCubbin, D. G.: Barrier-island and strand-plain facies, in: Sandstone Depositional Environments, edited by: Scholle, P. A. and Spearing, D., Memoir 31, AAPG, 247-258, 1982.

McHugh, C. M. G., Seeber, L., Cormier, M.-H., Dutton, J., Cagatay, N., Polonia, A., Ryan, W. B. F., and Gorur, N.: Submarine earthquake geology along the North Anatolia Fault in the Marmara Sea, Turkey: A model for transform basin sedimentation, Earth Planet. Sci. Lett., 248, 661-684, 2006.

Meltzner, A. J., Sieh, K., Chiang, H.-W., Shen, C.-C., Suwargadi, B. W., Natawidjaja, D. H., Philibosian, B., and Briggs, R. W.: Persistent termini of 2004- and 2005-like ruptures of the Sunda megathrust: J. Geophys. Res., 117, B04405, doi:10.1029/2011JB008888, 2012.

Mikada, H., Mitsuzawa, K., Matsumoto, H., Watanabe, T., Morita, S., Otsuka, R., Sugioka, H., Baba, T., Araki, E., and Suyehiro, K.: New discoveries in dynamics of an M8 earthquake-phenomena and their implications from the 2003 Tokachi-oki earthquake us- ing a long term monitoring cabled observatory, Tectonophysics, 426, 95-105, 2006.

Millspaugh, S. H., Whitlock C., and Bartlein, P. J.: Postglacial fire, vegetation, and climate history of the Yellowstone-Lamar and Central Plateau provinces, Yellowstone National Park, in: After the Fires: The Ecology of Change in Yellowstone National Park, edited by: Wallace, L., 10-28, Yale University Press, 2004.

Moernaut, J., De Batist, M., Charlet, F., Heirman, K., Chapron, E., Pino, M., Brümmer, R., and Urrutia, R.: Giant earthquakes in South-Central Chile revealed by Holocene mass-wasting events in Lake Puyehue, Sediment. Geol., 195, 239-256, 2007.

Nakajima, T. and Kanai, Y.: Sedimentary features of seismoturbidites triggered by the 1983 and older historical earthquakes in the eastern margin of the Japan Sea, Sediment. Geol., 135, 1-19, 2000.

Nelson, A. R., Kelsey, H. M., and Witter, R. C.: Great earthquakes of variable magnitude at the Cascadia subduction zone, Quaternary Res., 65, 354-365, 2006.

Nelson, A. R., Sawai, Y., Jennings, A. E., Bradley, L., Gerson, L., Sherrod, B. L., Sabean, J., and Horton, B. P.: Great-earthquake paleogeodesy and tsunamis of the past 2000 years at Alsea Bay, central Oregon coast, USA, Quaternary Sci. Rev., 27, 747-768, 2008.

Nelson, C. H.: Marine geology of the Astoria deep-sea fan [Ph. D. Thesis], Oregon State University, 287 pp., 1968.

Niemi, T. M. and Ben-Avraham, Z.: Evidence for Jericho earthquakes from slumped sediments of the Jordan River delta in the Dead Sea, Geology, 22, 395-398, 1994.

Noda, A., Tuzino, T., Kanai, Y., Furukawa, R., and Uchida, J. -I.: Paleoseismicity along the southern Kuril Trench deduced from submarine-fan turbidites, Mar. Geol., 254, 73-90, 2008.

Noren, A. J., Bierman, P. R., Steig, E. J., Lini, A., and Southon, J.: Millennial-scale storminess variability in the northeastern United States during the Holocene epoch, Nature, 419, 821-824, 2002.

O'Brien, N. R., Nakazawa, K., and Tokuhashi, S.: Use of clay fabric to distinguish turbiditic and hemipelagic siltstones and silts, Sedimentology, 27, 47-61, 1980.

Pareschi, M. T., Boschi, E., and Favalli, M.: Lost Tsunami, Geophys. Res. Lett., 33, L22608, doi:10.1029/2006GL027790, 2006.

Patton, J. R., Goldfinger, C., Morey, A., Erhardt, M., Black, B., Garrett, A. M., Djadjadihardja, Y. S., and Hanifa, U.: 7.5 ka earthquake recurrence history in the region of the 2004 SumatraAndaman earthquake, Geol. Soc. Am. Abstracts with Programs, 41, p. 408, 2009.

Piper, D. J. W.: Turbidite muds and silts on deep sea fans and abyssal plains, in: Sedimentation in Submarine Canyons, Fans and Trenches, edited by: Stanley, D. J. and Kelling, G., Dowden, Hutchinson and Ross, Stroudsburg, Pa, 163-176, 1978.

Piper, D. J. W. and Deptuck, M.: Fine-grained turbidites of the Amazon Fan: facies characterization and interpretation, edited by: Flood, R. D., Piper, D. J. W., Klaus, A., and Peterson, L. C., Proc. ODP, Sci. Res., 155, 77-108, 1997.

Piper, D. J. W., Shor, A. N., and Hughes Clarke, J. E.: The 1929 Grand Banks earthquake, slump and turbidity current, in: Sedimentologic Consequences of Convulsive Geologic Events, edited by: Clifton, H. E., Geol. Soc. Am., Special Paper 229, 77-92, 1988.

Porebski, S., Meischner, D., and Görlich, K.: Quaternary mud turbidites from the South Shetland Trench (West Antarctica): recog- 
nition and implications for turbidite facies modeling, Sedimentology, 38, 691-715, 1991.

Pouderoux, H., Lamarche, G., and Proust, J.-N.: Building an 18 000-year-long paleo-earthquake record from detailed deep-sea turbidite characterisation in Poverty Bay, New Zealand, Nat. Hazards Earth Syst. Sci., 12, 2077-2101, doi:10.5194/nhess-122077-2012, 2012.

Puig, P., Ogston, A. S., Mullenbach, B. L., Nittrouer, C. A., Parsons, J. D., and Sternberg, R. W.: Storm-induced sediment gravity flows at the head of the Eel submarine canyon, northern California margin, J. Geophys. Res., 109, C03019, doi:10.1029/2003JC001918, 2004.

Ramsey, C. B.: Development of the radiocarbon program OxCal, Radiocarbon, 43, 355-363, 2001.

Reimer, P. J., Baillie, M. G. L., Bard, E., Bayliss, A., Beck, J. W., Blackwell, P. G., Bronk Ramsey, C., Buck, C. E., Burr, G. S., Edwards, R. L., Friedrich, M., Grootes, P. M., Guilderson, T. P., Hajdas, I., Heaton, T. J., Hogg, A. G., Hughen, K. A., Kaiser, K. F., Kromer, B., McCormac, F. G., Manning, S. W., Reimer, R. W., Richards, D. A., Southon, J. R., Talamo, S., Turney, C. S. M., van der Plicht, J., and Weyhenmeyer, C. E.: IntCal09 and Marine09 radiocarbon age calibration curves, $0-50,000$ years cal BP, Radiocarbon, 51, 1111-1150, 2009.

Rogerson, M., Weaver, P. P. E., Rohling, E. J., Lourens, L. J., Murray, J. W., and Hayes, A.: Colour logging as a tool in highresolution palaeoceanography, in: New techniques in sediment core analysis, edited by: Rothwell, R. G. and Rack, F. R., Geol. Soc. Spec. Pub. 267, London, UK, Geol. Soc. London, 99-112, 2006.

Rothwell, R. G. and Rack, F. A.: New techniques in sediment core analysis, in: New techniques in sediment core analysis, edited by: Rothwell, R. G. and Rack, F. R., Geol. Soc. Spec. Pub. 267 : London, UK, Geol. Soc. London, 1-29, 2006.

Rupke, N. A. and Stanley, D. J.: Distinctive properties of turbiditic and hemipelagic mud layers in the Algero-Balearic Basin Western Mediterranean Sea, Smithsonian Contributions to Earth Sciences, 13, 1-40, 1974.

Schnellmann, M., Anselmetti, F. S., Giardini, D., and Ward, S. N.: Prehistoric earthquake history revealed by lacustrine slump deposits, Geology, 30, 1131-1134, 2002.

Seitz, G. G. and Kent, G. M.: Closing the Gap between On and Offshore Paleoseismic Records in the Lake Tahoe Basin, NEHRP Annual Report, 34, Reston, VA, US Geological Survey, 14, 2005.

Shennan, I, Long, A. J, Rutherford, M. M., Green, F. M., Innes, J. B., Lloyd, J. M., Zong, Y., and Walker, K. J.: Tidal marsh stratigraphy, sea-level change and large earthquakes I: A 5000 year record in Washington, USA, Quaternary Sci. Rev., 15, 10231059, 1996.

Shiki, T., Kumon, F., Inouchi, Y., Kontani, Y., Sakamoto, T., Tateishi, M., Matsubara, H., and Fukuyama, K.: Sedimentary features of the seismo-turbidites, Lake Biwa, Japan, Sediment. Geol., 135, 37-50, 2000a.

Shiki, T., Cita, M. B., and Gorsline, D. S.: Sedimentary features of seismites, seismo-turbidites and tsunamiites - an introduction, Sediment. Geol., 135, 2000b.

Smith, C. R., Pope, R. H., DeMaster, D. J., and Magaard, L.: Agedependent mixing of deep-sea sediments, Geochim. Cosmochim. Acta, 57, 1473-1488, 1993.
Sommerfield, C. K. and Nittrouer, C. A.: Modern accumulation rates and a sediment budget for the Eel shelf: a flood dominated depositional environment, Mar. Geol., 154, 227-241, 1999.

Sommerfield, C. K. and Wheatcroft, R. A.: Late Holocene sediment accumulation on the northern California shelf: Oceanic, fluvial, and anthropogenic influences, Geol. Soc. Am. Bull., 119, 1120 1134, 2007.

Spencer, E.: A method of analysis of the stability of embankments assuming parallel interslice forces, Géotechnique, 17, 11-26, 1967.

Stevenson, C. J., Talling, P. J., Wynn, R. B., Masson, D. G., Hunt, J. E., Frenz, M., Akhmetzhanhov, A., and Cronin, B. T.: The flows that left no trace: Very large-volume turbidity currents that bypassed sediment through submarine channels without eroding the sea floor, Mar. Pet. Geol., 41, 186-205, 2013.

St-Onge, G., Mulder, T., Piper, D. J. W., Hillaire-Marcel, C., and Stoner, J. S.: Earthquake and flood-induced turbidites in the Saguenay Fjord (Québec): a Holocene paleoseismicity record, Quaternary Sci. Rev., 23, 283-294, 2004.

Stow, D. A. V. and Bowen, A. J.: A physical model for the transport and sorting of fine-grained sediment by turbidity currents, Sedimentology, 27, 31-46, 1980.

Stow, D. A. V. and Piper, D. J. W.: Deep-water fine-grained sediments: facies models, in: Fine-Grained Sediments: Deep-Water Processes and Facies, edited by: Stow, D. A. V. and Piper, D. J. W., Geol. Soc. Spec. Pub. 15, London, 611-645, 1984.

Strasser, M., Anselmetti, F. S., Fäh, D., Giardini, D., and Schnellmann, M.: Magnitudes and source areas of large prehistoric northern Alpine earthquakes revealed by slope failures in lakes, Geology, 34, 1005-1008, 2006.

Stuiver, M. and Polach, H. A.: Discussion: Reporting of ${ }^{14} \mathrm{C}$ data, Radiocarbon, 19, 355-363, 1977.

Tan, B., Germaine, J. T., and Flemings, P. B.: Data report: Consolidation and strength characteristics of sediments from ODP Site 1244, Hydrate Ridge, Cascadia continental margin, edited by: Tréhu, A. M., Bohrmann, G., Torres, M. E., and Colwell, F. S., Proc. ODP, Sci. Results, 204, College Station, TX (Ocean Drilling Program), 1-148, http://www-odp.tamu.edu/ publications/204_SR/VOLUME/CHAPTERS/102.PDF ( last access: 9 September 2012), 2006.

Thomson, J. and Weaver, P. P. E.: An AMS radiocarbon method to determine the emplacement time of recent deep-sea turbidites, Sediment. Geol., 89, 1-7, 1994.

Thomson, J., Colley, J. S., and Weaver, P. P. E.: Bioturbation into a recently emplaced deep-sea turbidite as revealed by $210 \mathrm{~Pb}$ excess, 230Th excess and planktonic Foraminifera distributions, Earth Planet. Sci. Lett., 90, 157-173, 1988.

Thomson, J., Cook, G. T., Anderson, R., Mackenzie, A. B., Harkness, D. D., and McCave, I. N.: Radiocarbon Age Offsets In Different-Sized Carbonate Components Of Deep-Sea Sediments, Radiocarbon, 7, 91-103, 1995.

Thorbjarnarson, K. W., Nittrouer, C. A., and DeMaster, D. J.: Accumulation of modern sediment in Quinault submarine canyon, Marine Geol., 71, 107-124, 1986.

Tunnicliffe, V., Chapman, R., Yahel, G., and Wilmut, M.: Environmental Impacts of Air-gun Surveys on Glass Sponges, Canadian Ministry of Energy and Mines, 36 pp., 2008.

Valentine, D. W., Keller, E. A., Carver, G., Li, W. H., Manhart, C., and Simms, A. R.: Paleoseismicity of the Southern End of the 
Cascadia Subduction Zone, Northwestern California, Bull. Seismol. Soc. Am., 102, 1059-1078, 2012.

Waldmann, N., Anselmetti, F. S., Ariztegui, D., Austin, J. J. A., Pirouz, M., Moy, C. M., and Dunbar, R.: Holocene mass-wasting events in Lago Fagnano, Tierra del Fuego $\left(54^{\circ} \mathrm{S}\right)$ : implications for paleoseismicity of the Magallanes-Fagnano transform fault, Basin Research, 23, 171-190, 2011

Weber, M. E., Niessen, F., Kuhn, G., and Wiedicke, M.: Calibration and application of marine sedimentary physical properties using a multi-sensor core logger, Mar. Geol., 136, 151-172, 1997.

Wetzel, A. and Balson, P.: Sedimentology of fine-grained turbidites inferred from continuously recorded physical properties data Source, Mar. Geol., 104, 165-178, 1992.

Wheatcroft, R. A.: Experimental tests for particle size-dependent bioturbation in the deep ocean, Limnol. Oceanogr., 37, 90-104, 1992.

Wheatcroft, R. A. and Sommerfield, C. K.: River sediment flux and shelf accumulation rates on the Pacific Northwest margin, Cont. Shelf Res., 25, 311-332, 2005.

Whitlock, C., Larsen, C. P. S.: Charcoal as a fire proxy, in: Tracking Environmental Change Using Lake Sediments, Terrestrial, Algal, and Siliceous indicators, edited by: Smol, J. P., Birks, H. J. B., and Last, W. M., 3. Kluwer Academic Publishers, Dordrecht, 7597, 2001.
Whitlock, C., Marlon, J., Briles, C. E., Brunelle, A., Long, C., and Bartlein, P.: Long-Term Relations Among Fire, Fuel, And Climate In The North-Western US Based On Lake-Sediment Studies, Int. J. Wildland Fire, 17, 72-83, 2008.

Witter, R. C., Kelsey, H. M., and Hemphill-Haley, E.: Great Cascadia earthquakes and tsunamis of the past 6700 years, Coquille River estuary, southern coastal Oregon, Bull. Geol. Soc. Am., 115, 1289-1306, 2003.

Witter, R. C., Zhang, Y. J., Wang, K., Goldfinger, C., Priest, G. R., and Allan, J. C.: Coseismic slip on the southern Cascadia megathrust implied by tsunami deposits in an Oregon lake and earthquake-triggered marine turbidites, J. Geophys. Res., B10303, doi:10.1029/2012JB009404, 2012.

Zdanowicz, C. M., Zielinski, G. A., and Germani, M. S.: Mount Mazama eruption: Calendrical age verified and atmospheric impact assessed, Geology, 27, 621-624, 1999.

Zúñiga, D., García-Orellana, J., Calafat, A., Price, N. B., Adatte, T., Sanchez-Vidal, A., Canals, M., Sanchez-Cabeza, J. A., Masqué, P., and Fabres, J.: Late Holocene fine-grained sediments of the Balearic Abyssal Plain, Western Mediterranean Sea, Mar. Geol., 237, 25-36, 2007. 